فاعلية بعض الاستراتيجيات التعليمية في تنمية مستويات التحصيل الدراسي لاى طلاب كلية الثريعة ـ جامعة الإمام محمد بن سعود الإسلامية "دراسة تجريبية مقارنة مقن

إعداد

د/ سليمان بن عبد الله الدويش

أستاذ مساعد بقسم المناهج وطرق التدريس كلية العلوم الاجتماعية ـ "جامعة الإمام محمد بن سعود الإسلامية"

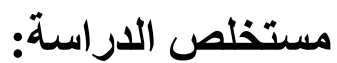

تتثثل مشكلة الدراسة في الكثف عن أثر التكامل بين إستراتيجيني التعلم التعاوني و التعلم الذاتي مقارنة بإستر اتيجيتي المحاضرة المعدلة و المحاضرة التقليدية في تنمية التحصيل لدى طلاب كلية الثريعة بجامعة الإمام محمد بن سعود الاسلامية. وتجيب عن السؤال الرئيس الآتي: "هل يوجد اختلاف في أثر استخدام التكامل بين إستراتيجيتي التعلم التعاوني و التعلم الذاتي، وأثر استخدام إستر اتيجية المحاضرة المعدلة مقارنة باستخدام إستراتيجية المحاضرة العادية (التقليدية) في تتمية التحصيل لدى طلاب كلية الثريعة بجامعة الإمام في مقرر المناهج وطرق التدريس (ترب اOبץ) في المستويات المعرفية عند بلوم؟". ويتفرع منه الإجابة عن الأسئلة التالية: هل يوجد اختلاف في أثر استخدام التكامل بين إستر اتيجيتي التعلم التعاوني و التعلم الذاتي وبين استخدام إستر اتيجية المحاضرة المعدلة والمجمو عة الضابطة التي درست باستخدام إستر اتيجية المحاضرة العادية في تتمية التحصيل لاى طلاب كلية الثريعة بجامعة الإمام في مقرر المناهج وطرق التدريس: أـ في كل مستوى من المستويات المعرفية الستة وفق تصنيف بلوج؟ ب - و المستويات المعرفية الدنيا؟ ج - و المستويات المعرفية

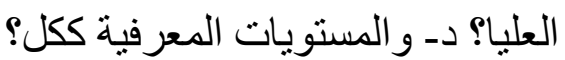
وقد اعتمدت الدراسة على المنهج شبه التجريبي وتكون مجتمع الدر اسة من طلاب المستوى السادس في كلية الثريعة بجامعة الإمام محمد بن سعود الإسلامية، وبلغت عينة الدراسة (135) طالباً، موزعين على ثلاث مجموعات: الأولى والثانية تجريبيتين والثالثة ضابطة، وقد بلغ عدد المجموعة التجريبية الأولى (46) طالباً، وبلغ عدد الدجموعة التجريبية الثانية (45) طالبا، وبلغ 
عدد المجموعة الضابطة الثالثة (44) طالبا ودرسوا جميعا مكونات المنهج المدرسي (الأهداف، المحتوى، الأنشطة التعليمية، التقويم) باستخدام الإستر اتيجيات الثلاث، وتم اختيار العينة بالأسلوب القصدي، وكانت أداة الدراسة اختبار يتكون من (24) سؤالاً موز عة حسب المستويات المعرفية بلتئية

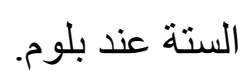
أهم النتائج: أن التدريس باستخدام التكامل بين إستر اتيجيتي التعلم التعاوني والتعلم الذاتي، جاء بالمرتبة الأولى، وأن التدريس باستخدام إستر اتيجية المحاضرة المعدلة، جاء بالمرتبة الثنانية،

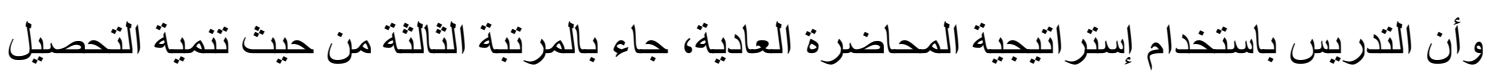
ومستويات التفكير، و اكساب المعارف و الدفاهيم و الحقائق العلمية لدى العينة. أهم التوصيات: 1- الاهتمام باستخدام الاستراتيجيات الحديثة في التدريس ـ كإستراتيجية التكامل

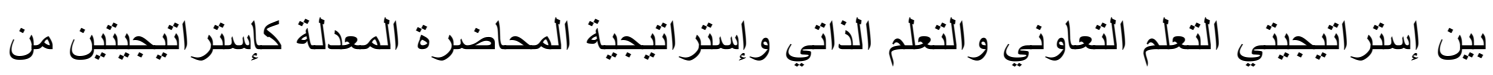
إستر اتيجيات التعلم النشط - وذلك لما لهما من أثر في تنمية التحصيل و اكساب المعارف و والحقائق العلمية وتنمية مستويات التفكير لدى الطلاب في المستويات المعرفية بشكل عام. 2-أهية التتوع في استخدام استراتيجيات التعلم النشط و الاهتمام بالاستر اتيجيات التدريسية الحديثة التي تساعد على التحصيل وتتمية قدر ات التفكير المختلفة. أهم المقترحات: 1- التوسع في استخدام الاستراتيجيات التكاملية، وتطوير الطرق التوات الفية التي تجمع بين أكثر من استراتيجية واحدة، وأن هذا المنحى يعد بنتائج إيجابية في مجال الأبحاث و الدراسات التربوية وفي مجال تطوير التعليه. r ـ إجراء دراسات حول أثر استخدام كل من استر اتيجية التكامل بين إستر اتيجيتي التعلم التعاوني

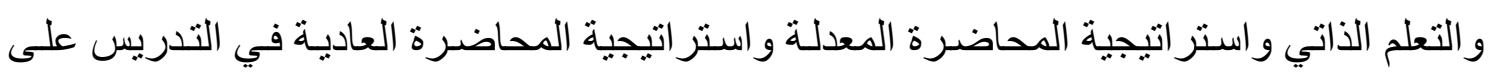
تتمية التحصيل في بعض المقرر ات الدراسية الأخرى في التعليم الجامعي وفي التعليم العام. المقدمة: تولي الدول اهتماما كبير التتمية وتطوير الإنسان و المجتمع، إدر اكا منها أن أعظم استثمار و أنفعه

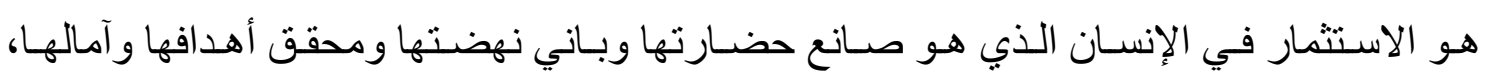
و العصر الذي نعيشه يتميز بسر عة التطور وكثافة المعلومات وتعدد وسائل التعلم و التعليم وتقنياتهما

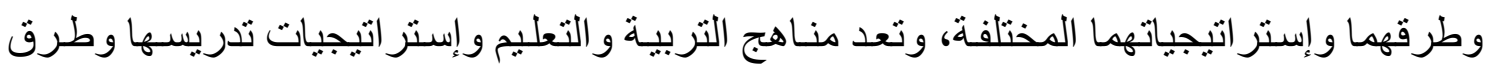


توصيلها للمنعلمين وتحقيق نو اتج التعلم و التعليم الأهم و الأكثر فعالية في التأثير في رقي الأمم ونهضتها. إن تطوير المناهج وتحديثها واستخدام أفضل الوسائل المعينة والطرق والاستر اتيجيات الموصلة

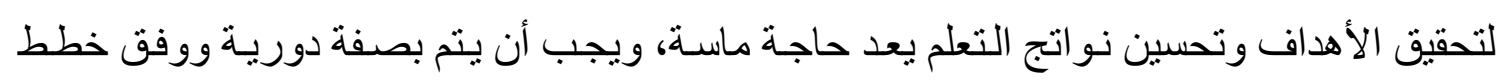

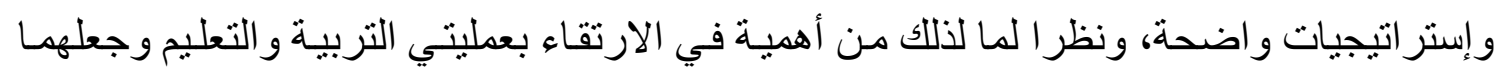

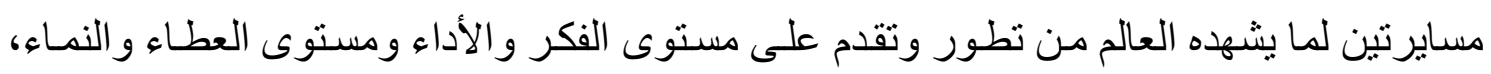

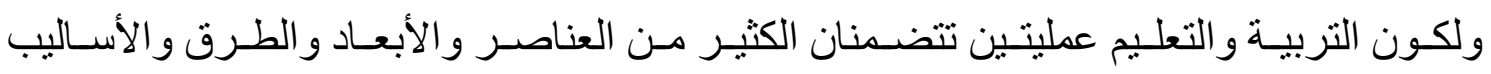

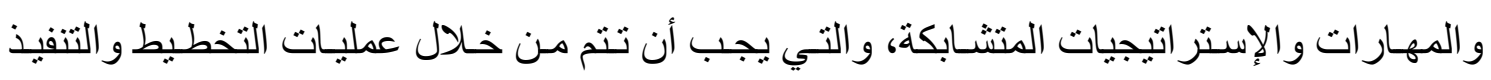

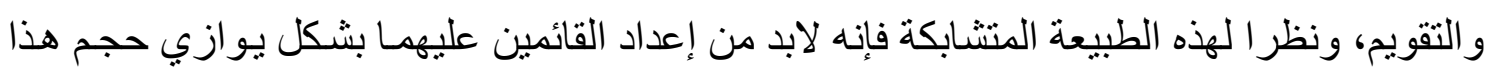

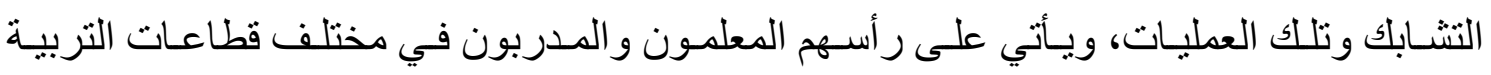

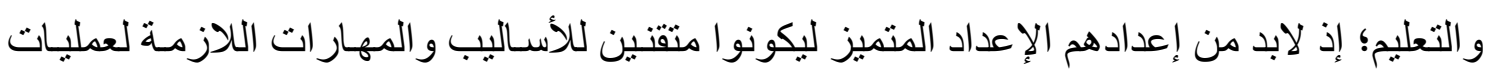

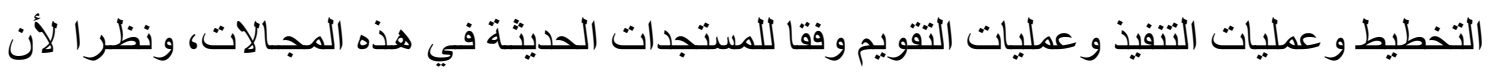

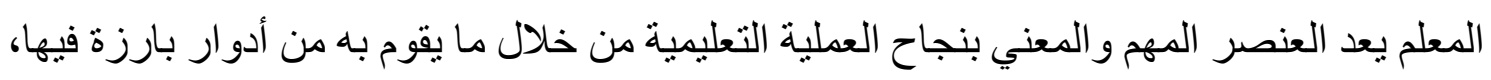

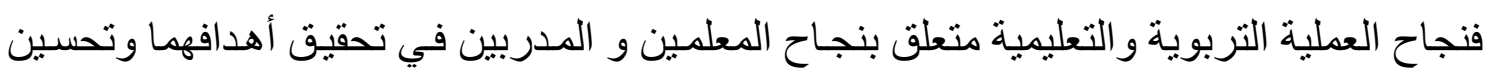

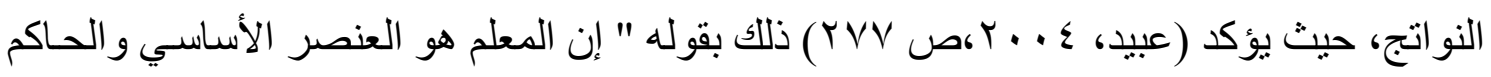
في العملية التعليمية وله الدور الفاعل و المؤثر في تحديد جودة مخرجات العيد العطية التعليمية فمهيا

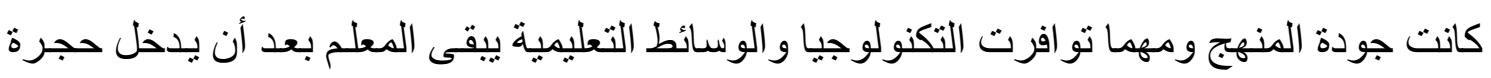
الدر اسة ويختلي بطلابه هو سيد الموقف في استثمار الإمكانات المتاحة لتحريك عقولهم ".

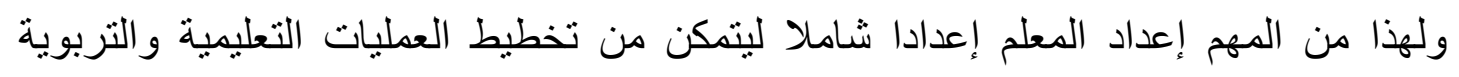
وتنفيذها على الوجه المطلوب، ويكون قادرا على إجراء عمليات التقويم المتتابعة والمستمرة لها،

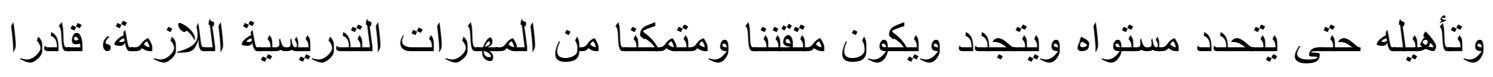

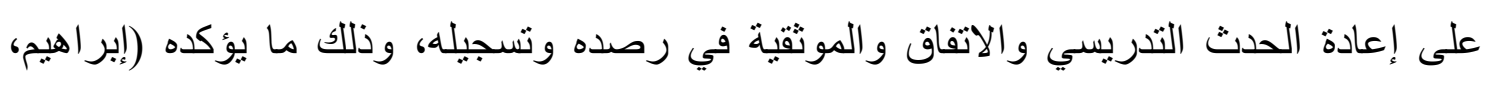

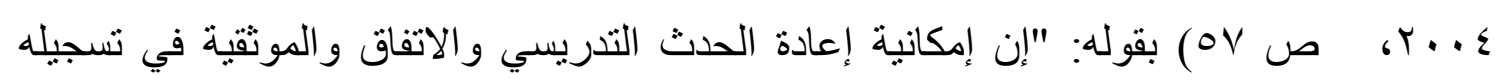
ورصده أصبحت ذات قيمة لقدرته

على تحديد سلوك المعلم وتوقعاته من الطلاب، وأداء الطلاب الصفي وتحديد درجة تحصيلهم

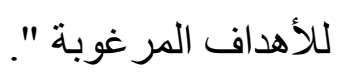


كما أن تفاعل المتعلمين و إثارة دافعيتهم نحو التعلم وتتمية مهارات التفكير العليا لديهم - خاصة في التعليم العالي - يعد مطلبا مهما يقع على الأساتذة العبء الأكبر منه أثناء قيامهم بعمليات التدريس، ويتطلب هذا منهم التنويع والتطوير والابتكار في طرق إيصال المعلومات إلى المتعلمين وتحقيق أهداف التعلم والتعليم بطرق و إستراتيجيات متعددة وسهلة وميسرة ومفهومة وجاذبة، مستخدمين في ذللك كافة الأساليب و الوسائل والتقنيات المناسبة والمتاحة، فبالرغم من الجهود الكبيرة التي يحظى بها التعليم في الوقت الحاضر من خلال كثير من المشاريع التي تركز على تطويره وتجويده إلا أنه يحتاج إلى المزيد من العناية والاهتمام خاصة فيما يتعلق بأساليب وطرق و إستر اتيجيات التدريس، والحاجة إلى استمر ارية إعداد المعلمين وتدرييهم وتقويمهم في ضوء ما يمتلكونه وما يكتسبونه من مهار ات لاشك أنه يساهم في إنماء عمليات التدريس وتقليل فجوات التعليم، وبالر غم من أن المعلمين استخدموا دوما أساليب وطرق و إستر اتيجيات إلا أنه لم يكن في حوزتهم ولا بمقدور هم - حتى وقت قريب - إلا القليل منها منل: المناقثة والعرض و المحاضرة و الممارسة والاختبار، إلا أن الباحثين والمعلمين - في السنوات الخمسين الأخيرة - كما يقول (هارفي وآخرون، V + . . م): ابتكروا ونقحوا و عدلوا وأعادو ا تشكيل هذه العناصر الخمسة هن خلال مئات الصور الجديدة " و الأساليب والطرق والإستر اتيجيات التدريسية التقليدية التي لا تهتم بإحداث تعلم حقيقي يكون ذا معنى في نفوس المتعلمين ويلمس أثره في سلوكهم وينعكس على أدائهم ويجعلهم مؤثرين في مجتمعاتهم قد ينظر إليها على أنها قد تكون سببا من أسباب تخلفهر وتأخر مجتمعاتهم، وأنها لا تحقق أهداف التربية والتعليم التي تصبو لتحقيقها الأمم و المجتمعات، إذا كما يقول (الدريج، §99 99 م ): "ما هو السبيل إلى تجاوز النموذج التقليدي أو على الأقل بعض سلبياته في التدريس؟ والحقيقة أن المشكلة ليست في تجاوز النموذج التقليدي، بل تكمن في اكتشاف طرق و استراتيجيات حديثة تكون معينة للطرق التقليدية وحسن توظيف كل من الحديث و التقلبدي فيما يناسبه ويتطلبه من مو اقف تعليمية"ص r 7 . إن حث المتعلمين وحفز هم وإثارة دافعيتهم نحو التعلم والتفاعل الإيجابي المخطط و المشاركة الفاعلة والتعاون المستمر بين أطراف الموقف التعليمي داخل القاعات التدريسية أو خارجها بعد عاملاً مهماً في حدوث التعلم الحقيقي - وبالذات في التعليم الجامعي ـ وتجاوز النموذج التقليدي، فمن خلال المشاركة الفاعلة والبحث والاطلاع، و التقصي العلمي وحل المشكلات التي تعترض طريق المتعلمين وتؤرقهم، وتَكَينهم من امتلاك زمام المبادرة في الأنشطة المختلفة التي يمارسونها 
سعياً لتحقيق أهداف تعلمهم بمشاركة أساتذتهم وزملائهم، وتوفير بيئة تعليمية فاعلة متنو عة تسمح لهم بالإصغاء الإيجابي، والحوار البناء، وتعينهم على التحليل السليم، والتأمل العميق، والتفكير الو اعي لكل ما يتم طرحه أو قر اءته أو كتابته من مو اد تعليمية، أو قضايا بحثية، ومناقثتها مناقشة هادفة، مع وجود من بشجعهم على تحمل مسؤولية التعلم، و بسهم في دفعهم لتحقيق أهداف المنهج وتعلم محتو اه بفعالية، بما ينمي لديهم القدرة على التحليل والتبصر والتدبر وربط ذلك في المواقف الحياتية المختلفة، وتكوين القيم والاتجاهات، كل ذلك يسهم في بقاء أثر التعلم في الفكر والوجدان، وفي تفعيل دور المتعلمين والاعتناء بهم لكي يمر التعلم من خلال نشاطات تعلم وتجريب حقيقية، وممارسات عملية وباعتماد من المتعلمين على ذواتهم في الحصول على المعلومات، واكتساب المهار ات، وتغيير السلوكيات، وبهذا يحدث التعليم والتعلم الحقيقي ويعد ذلك تعليما وتعلما تفاعليا

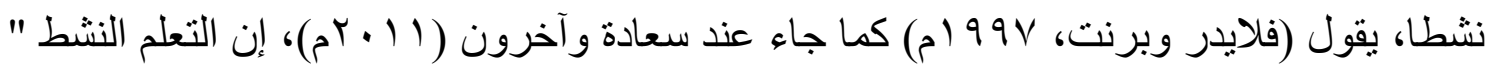
عملية إثخال الطلبة بشكل نشط ومباشر في عملية التعلم و لاسيما من حيث القراءة و الكتابة و التفكير والتأمل، حيث يقومون بعمليات المشاركة والتطبيق بدلا من الاقتصار على عملية استقبال المعلومات اللفظية المسموعة أو المرئية المكتوبة أو المطبو عة ". إن التعليم والتعلم الاستر اتيجي المطلوب، والتدريس الفعال الذي من خلاله يحدث التعلم النشط الأكثر فعالية؛ وتزداد به التقة بالنفس وتمارس مهار ات التفكير من خلال مشاركة المتعلمين الواعية بالأنشطة المتتوعة، ومنه مثلا أن بعد المتعلمون المواد العلمية ويقومون بتقديمها وطرحها أمام زملائهم تحت إشر اف دقيق مخطط هادف من أساتذتهم، وباستخدام تقنيات التعلم المختلفة وتوظيف إمكاناتهم كل فيما يتقن ويحب، وأن يعدو أوراق عمل فردية وجماعية حول موضو عات ذات علاقة بمفردات المنهج وتحقيق أهدافه يقومون بتقديمها أمام زملانهم، وأن بطرحوا الأسئلة ويشتركو ا في المناقثات والحوار ات النشطة فرادا أو في مجموعات العمل المشكلة المشتركة، وأن بسهموا في اقتر اح لحل المشكلات مبني على خطو ات علمية، والإفادة من التعلم و التعليم في التطبيقات الحياتية العملية المختلفة، لا يمكن أن يتحقق ذلك إلا بدور فاعل واع من قبل أساتذتهم، وتخطيط استراتيجي، وبذل في استخدام كل الطرق والوسائل المعينة والإمكانات المتاحة بأقصى درجات الاستخدام وبفعالية هادفة لإحداث بيئة خاصة بالتعلم النشط، يذكر (موديل ومايكل، ب99 (م) حول هذه البيئة بأنها " البيئة التي يتم فيها تشجيع المتعلمين بشكل فردي على المشاركة في عملية بناء نماذجهم 
العقلية من المعلومات التي يكتسبونها،بالإضافة إلى ضرورة اختبار صدق النموذج الذي قاموا ببنائه كجز ع من عملية التعلم النشط". و على الرغم من أن المسؤولية النهائية للتعلم تقع على عاتق المتعلمين إلا أن التدريس الجيد يثجع على بذل المزيد من الجهد لبذل مزيد من الفرص الكافية للممارسة والتدريب من جهة، ويوفر تغذية راجعة حول أدائهم، ويمنحهم الحرية في التعلم حيث تعتبر هذه من الصفات الضرورية للتعلم النشط الذي يربط المتعلم بالمادة الدراسية التي يتعلمها، ففي داخل الحجرة الدر اسية يقوم المعلم بتدريس الطلبة كيفية العمل، وكيفية القيام بالمهمة أو الواجب الذي يتمثى مع المقرر الدراسي، أو ما يدور من مناقتنات أو فعاليات مع الآخرين بحيث يتم توزيع مسؤولية التعلم بين المتعلمين والمعلم، وهذا ما أكدته دراسة (فوكس، 991 ( م) من ضرورة وأهمية تشجيع المتعلمين على التفاعل في التعلم النشط حيث بينت أن التعلم النشط يعمل على إبقاء ودعم عمليات التعلم لدى المتعلمين، وأوصت الدراسة بأن يعدل الأساتذة من أساليب تعليمهم باعتماد الوسائط المتعددة المختلفة تحقيقاً لمزيد من التفاعل الإيجابي. ويتطلب مثل هذا الأمر تبني مزيدٍ من الاستر اتيجيات التدريسية التفاعلية الحديثة التي تدعم هذه المبادئ - وخاصة في التعليم الجامعي - سعياً في إحداث التعلم النشط و المر غوب للطالب الجامعي، ومقارنة أيها أكثر فعالية وتحقيقا لأهداف التعليم والتعلم ولتقليل فجوات التعليم، والتأكد أن ذلك النوع من التعلم الذي يعمل فيه المتعلم على تكوين المعنى والتعاون مع الآخرين ضمن أجواء يقل فيها التركز على استقبال المعرفة المستقاة من المعلم ومحاضراته ويزيد من قدرة المتعلمين على التأمل والاكتشاف، ويركز على تحقق المستويات المعرفية العليا، من هنا جاءت فكرة دراسة تجريب تكامل استراتيجيتين من استراتيجيات التعلم النشط هما: (استراتيجية التعلم التعاوني، و إستراتيجية التعلم الذاتي) ومقارنة نتائج استخدامها مع نتائج استخدام إستراتيجية المحاضرة المعدلة وإستر اتيجية المحاضرة التقليدية في تنمية التحصيل لاى طلاب كلية الثريعة بجامعة الإمام، وذللك بغية الوصول وبشكل تجريبي إلى الأفضل و الأكثر فاعلية وتحقيقا للأهداف ونواتج التعليم، فالتكامل بين طرق التدريس واستراتيجياته المختلفة والتعديل فيها وفق ظروف البيئة الصفية - رغم ما تتصف به كل منها منفردة من دور نشط للمتعلم و لما لكل منها من محفز ات وما لها في نفس الوقت من معيقات و عقبات تُغلب غالبا استخدام إحداها على الأخرى - وتجريب ذلك 
ومقارنة النتائج يعد مطلبا حقيقياً لإحداث ولحدوث التعليم والتعلم الصحيح وردم فجوة التعليم وتحقيق متطلبات الجودة فيه. قضية الاراسة: لئن كانت الجامعات في المجتمعات من أهم الركائز و المحاضن التي يتم من خلالها بنـاء الإنسـان و إعـداده بشـكل يحقـق الاسـتثمار الأمثل فيـه، و الـذي يعـد أفضـل اسـتثمار ات الأمـم و المجتمعـات و أعظمها. و الجامعات هي التي يُعتمد عليها في سد احتياجات المجتمعات وسوق العمل فيها بثكل مباشر أو غير مباثر ، فالتأهيل والإعداد العلمي وحتى المهني اليوم منوط بها، حيث يفترض في خريجيهـا أن يتبـو عوا كـل الأمـاكن و الفـرص الوظيفيـة و المهـن المتاحسة فـي الإدار ات المختلفـة الحكومية و الأهلية منهـا على حد سواء، كما يعتمد عليهم بشكل مباشـر في سد النقص في جميع التخصصات و المهن التي يُحتاج إليهم فيها، ودن هنا كان من المفترض أن يتم تأهيل المتعلمين فيها و إعدادهم بشكل يمكنهم مـن أداء أعمـالهم بشكل صـيح ومتقن، ولن يتأتى لهم ذلك وهم يتلقون تعليمهم العالي بطرق تقليدية، تركز في مجملها على التعليم والتعلم وفق النموذج التقليدي المتمركز حول الطريقة الإلقائية والتي من أساليبها المحاضرة التقليدية، وما يقوله الأستاذ الجامعي ويفعله بـالا

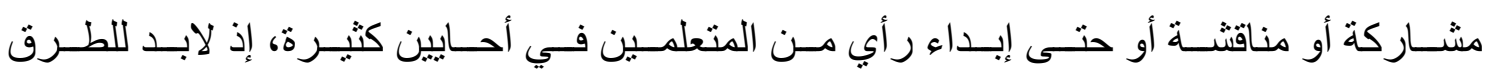
وللإستر اتيجيات التدريسية سواءً الحديثة منها أو التقليديـة ـ التي يجب تعديلها لتلافي مـا قد يكون فيها من سلبيات ـ و التي يمارسها عضو هيئة التدريس أن تحقق مبـادئ التعلم النشط، خاصـة وهي تُعدّ اليوم من مكونات المنهج الرئيسة لما لها من أثر بالغ في توصيل المحتوى وتحقيق أهداف التعلم

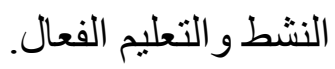
إن تحقيق أهداف التعلم وتدريس المناهج وتتفيذ توصيف المقررات والمحتوى في حجرات الدرس و إثر اء معارف المتعلمين وتتمية تفكير هم وتغيير سلوكهم، في مختلف مستويات التعليم العام و التعليم الجامعي يحتاج إلى استخدام الأساليب التدريسية والطرق والاستراتيجيات المختلفة و الحديثة وتزداد أهمية ذلك في التعليم الجامعي خاصة وأن المتعلمين في الجامعات أكثر قدرة على تحقيق الأهداف وتطبيق التوجهات الحديثة في التعليم والتي من أبرزها أن المتعلم هو محور العملية التعليمية، و المتعلمون في هذه المرحلة أكثر إدراكا وأكبر استفادة وتوظيفا لما يتعلمونه، فالحاجة ماسة لأن تتعدد هذه الطرق وتللك الأساليب والاستر اتيجيات وأن يكون استخدامها مبنيا على أسس ودر اسات علمية، وقد بينت بعض الدراسات أثر استخدامها في تحقيق نواتج التعلم وقارنت بينها، 
و أكدت أهمية التدريس باستخدام الإستر اتيجيات التي تحقق نواتج تعلم عالية، ومنها استر اتيجيات التعلم النشط، وفي مختلف مراحل التعليم، وقد أشارت على سبيل المثال دراسة كريستيانسون وفيشر Chirstianason \& Fisher)، (1999، ودر اسة هول وليبيرمان ( Hall\& Lieberman, 2004)، و دراسة جنيفر (Jennifer, 2005)، ودراسة الجهيمي (• • • (Yم)، ودراسة العنزي

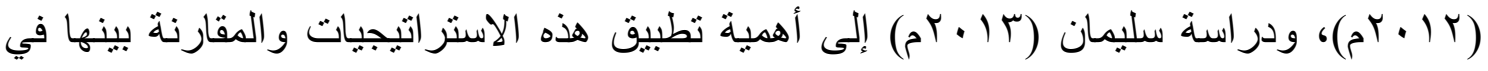
عمليات التدريس وفي مقررات در اسية عديدة سعيا للوصول إلى أفضلها، وضرورة التدريب عليها بهذف تحقيق نواتج تعلم أفضل، ورفع مستوى المتعلمين في التحصيل الدراسي في مختلف المقررات الدراسية؛ ذلك لأن اكتساب المتعلمين للمفاهيم المختلفة والحقائق العلمية، ومعالجتها بشكل جيد يُعدّ من الأهداف الهامة التي تسعى التربية إلى تحقيقها، ولا بتحقق ذلك إلا باستخدام أفضل الاستر اتيجيات في التدريس، ولما كان استخدام هذه الإستر اتيجيات وتطبيقها و المقارنة بينها قليلا في مختلف مر احل التعليم رغم أهميتها فالحاجة تدعو إلى المزيد من الاستخدام والتجريب و المقارنة بينها لاختيار أفضلها في تحسين عملية التعلم والتعليم كأحد التطبيقات التربوية المعاصرة في التعليم، ودر اسة فعاليتها في تنمية التحصيل، وفي تتمية مستويات التفكير العليا وتغيير سلوك المتعلمين، بل لابد من التكامل بينها واستخدام أكثر من استراتيجية واحدة في الموقف التعليمي الواحد، وفي المواقف المختلفة بحسب ما يقتضيه الحال ويقدره المعلم بمشاركة المتعلمين، ونظراً للأدو ار الكبيرة التي تحققها أهم إستر اتيجيين من إستر اتيجيات التعلم النشط وهما إستر اتيجية التعلم الذاتي و إستراتيجية التعلم التعاوني، فقد رأى الباحث تطبيق وتجريب هاتين الإستر اتيجيتين بشكل تكاملي، ومقارنة نتائج ذلك مع استخدام إستراتيجية المحاضرة المعدلة منفردة، ومع استخدام استراتيجية المحاضرة العادية (التقليدية) وذلك على طلاب المستوى السادس في كلية الشريعة بجامعة الإمام محمد بن سعود الإسلامية في مقرر المناهج وطرق التدريس (ترب اهب) للتعرف على أيها أكثر تأثير اوكفاءة في رفع مستويات المعرفة وتنمية مستويات التحصيل المختلفة، خاصة و أن هنالك محاو لات جادة لتطوير وتعديل أسلوب المحاضرة التقليدي لدى كثير من المختصين ومن يقومون بالتعليم وبالذات أساتذة الجامعات، بل عدها بعضهم إستراتيجية من إستر اتيجيات التعلم النشط بعد تعديلها وتطوير ها و إدخال التحسينات التي فرضت نفسها عليها و عليهم، وقد جاءت فكرة هذه الدراسة لدى الباحث نتيجة استخدام عدد من الإستراتيجيات في مواقف تعليمية مختلفة ولسنوات متعددة، وتولد من ذلك قناعة في أن مزاوجة أكثر من إستر اتيجية، وتكاملها يحقق نتائج 
أكبر، وأن استخدام استراتيجية المحاضرة المعدلة كذلك يحقق نتائج مرتفعة مقارنة بأسلوب المحاضرة التقليدي وبغير ها من إستر اتيجيات التعلم الحديثة ومنها إستر اتيجيات التعلم النشط، لكنه لم يكن متأكداً من أبها أكثر نفعا وتحقيقا لنواتج التعلم وأهدافه بشكل مفصل في مستويات المعرفة المختلفة، ومن هذا المنطلق قام بإجر اء التجربة. و ون هنا فإن هذه الدراسة جاءت لتسهم في هذا الاتجاه وبشكل واقعي تجريبي، خاصة أن الإستر اتيجيات التدريسية التي سيتم تطبيقها وتجريبها في هذه الدراسة هي من أهم وأبرز وأشهر ما يستخدمه أعضاء هيئة التدريس في قاعات الدرس، بل قد تكون هي السائدة والرائدة من بين الإستر اتيجيات و الطرق الأخرى، لذا فإن الباحث يأمل أن تسهم الدراسة في الكثف عن فعالية وأثر التكامل بين إستراتيجيتي التعلم التعاوني والتعلم الذاتي مقارنة بفعالية إستراتيجيتي المحاضرة المعدلة والمحاضرة العادية في تتمية التحصيل لدى طلاب كلية الثريعة بجامعة الإمام في مقرر المناهج وطرق التدريس (ترب (0)ب)، وذلك لما وجده الباحث من خلال التدريس باستخدام هذه الإستر اتيجيات و الطرق في عدة سنوات ولثرائح كبيرة من المتعلمين من تجاوب وتفاعل وحرص وزيادة في الدافعية نحو التعلم، ونتائج ملموسة تجاه استخدام هذه الإستر اتيجيات والطرق الحديثة في التدريس - بل و ذكر بعض المتعلمين أنهم لم يتعلمو ا بهذه الطرق ولم تمر عليهم طرق تقويم التحصيل المرتبطة بها من قبل، - ونظراً لتزايد الاهتمام بها يوما بعد يوم، ولكونها تتمشى مع المعايير العالمية للتدريس، وتعد من متطلبات الجودة في التعليم، ولقلة الدراسات ـ حسب علم الباحث ـ التي تزاوج وتكامل بين طرق التدريس و استر اتيجياته المختلفة وتقارن بينها وبين القديم و القديم المعدل سعيا إلى نموذج أفضل يساعد المعلمين على تحسين أدائهم ويساعد المتعلمين على تحسين وزيادة تحصيلهم و إكسابهم اتجاهات إيجابية نحو التعلم والتعليم، ولإجابة على أسئلة تلح على الباحث من خلال ممارسته لهذه الاستر اتيجيات و الطرق بغية التعرف على الأفضل، كل ذلك شجع على إجراء تجربة وهي دراسة أثر التكامل بين إستراتيجيتي التعلم التعاوني والتعلم الذاتي مقارنة بإستر اتيجيتي المحاضرة المعدلة و المحاضرة التقليدية في تنمية التحصيل لاى طلاب كلية الشريعة بجامعة الإمام محمد بن سعود الإسلامية. ومن هنا فهذه الدر اسة تجيب عن السؤال الرئيس الآتي: 
ما فاعلية التكامل بين إستراتيجيتي التعلم التعاوني والتعلم الأتي، و إستراتيجية المحاضرة المعدلة مقارنة بإستراتيجية المحاضرة العادية (التقليدية) في تتمية التحصيل لاى طلاب كلية الثريعة بجامعة الإمام في مقرر المناهج وطرق التدريس؟ وبالتحديد تحاول الدر اسة الإجابة عن الأسئلة التالية:

1. ما فاعلية استخدام التكامل بين إستراتيجيتي التعلم التعاوني والتعلم الذاتي وبين استخدام إستراتيجية المحاضرة المعدلة مقارنة باستخدام إستراتيجية المحاضرة العادية في تتمية التحصيل لدى طلاب كلية الثريعة بجامعة الإمام في مقرر المناهج وطرق التذريس في المستويات المعرفية وفق تصنيف بلوم؟ 2. ما فاعلية استخدام التكامل بين إستراتيجيتي التعلم التعاوني والتعلم الذاتي وبين استخدام إستر اتيجية المحاضرة المعدلة مقارنة باستخدام إستراتيجية المحاضرة العادية في تتمية التحصيل لدى طلاب كلية الثريعة بجامعة الإمام في مقرر المناهج وطرق التدريس في المستويات المعرفية وفق تصنيف بلوم؟ 3. ما فاعلية استخدام التكامل بين إستراتيجيتي التعلم التعاوني والتعلم الذاتي وبين استخدام إستراتيجية المحاضرة المعدلة مقارنة باستخدام إستراتيجية المحاضرة العادية في تتمية التحصيل لدى طلاب كلية الثريعة بجامعة الإمام في مقرر المناهج وطرق التدريس في المستويات المعرفية العليا وفق تصنيف بلوم المعرفي؟ 4. ما فاعلية استخدام التكامل بين إستراتيجيتي التعلم التعاوني والتعلم الذاتي وبين استخدام إستراتيجية المحاضرة المعدلة مقارنة باستخدام إستراتيجية المحاضرة العادية في تتمية التحصيل لدى طلاب كلية الثريعة بجامعة الإمام في مقرر المناهج وطرق التدريس في المستويات المعرفية ككل وفق تصنيف بلوم المعرفي؟

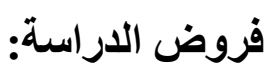

تحاول الدر اسة الحالية التأكد من صحة الفروض التالية: ا. لا توجد فروق ذات دلالة إحصائية عند مستوى دلالة (0.05) بين كل من المجموعة التجريبية الأولى التي درست باستخدام التكامل بين إستر اتيجيتي التعلم التعاوني و التعلم الذاتي و المجمو عة التجريبية الثانية التي درست باستخدام إستر اتيجية المحاضرة المعدلة و المجموعة الضابطة التي درست باستخدام إستراتيجية المحاضرة العادية في درجات المستويات 
المعرفية (التذكر - الفهم - التطبيق ـ التحليل ـ التركيب التقويم) كل على حدة من الاختبار التحصيلي لدى طلاب كلية الثريعة بجامعة الإمام في مقرر المناهج وطرق التدريس. 2. لا توجد فروق ذات دلالة إحصائية عند مستوى دلالة (0.05) بين كل من المجموعة التجريبية الأولى التي درست باستخدام التكامل بين إستر اتيجيتي التعلم التعاوني و التعلم الذاتي و المجمو عة التجريبية الثانية التي درست باستخدام إستر اتيجية المحاضرة المعدلة والمجموعة الضابطة التي درست باستخدام إستر اتيجية المحاضرة العادية في درجات المستويات الدنيا من الاختبار التحصيلي لاى طلاب كلية الثريعة بجامعة الإمام في مقرر المناهج وطرق التدريس. 3. لا توجد فروق ذات دلالة إحصائية عند مستوى دلالة (0.05) بين كل من المجموعة التجريبية الأولى التي درست باستخدام التكامل بين إستر اتيجيتي التعلم التعاوني و التعلم الذاتي و المجمو عة التجريبية الثانية التي درست باستخدام إستراتيجية المحاضرة المعدلة و المجمو عة الضابطة التي درست باستخدام إستر اتيجية المحاضرة العادية في درجات المستويات العليا من الاختبار التحصيلي لاى طلاب كلية الثريعة بجامعة الإمام في مقرر المناهج وطرق التدريس. 4. لا توجد فروق ذات دلالة إحصائية عند مستوى دلالة (0.05) بين كل من المجموعة التجريبية الأولى التي درست باستخدام التكامل بين إستر اتيجيتي التعلم التعاوني و التعلم الذاتي و المجمو عة التجريبية الثانية التي درست باستخدام إستر اتيجية المحاضرة المعدلة والمجموعة الضابطة التي درست باستخدام إستر اتيجية المحاضرة العادية في درجات الاختبار التحصيلي للمستويات المعرفية ككل لاى طلاب كلية الثريعة بجامعة الإمام في مقرر المناهج وطرق

$$
\text { التدريس. }
$$

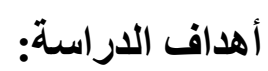

تهدف هذه الدراسة إلى الوقوف على أثر استخدام بعض استر اتيجيات التعلم النشط بعد توليفها ومحاولة التخلص من السلبيات التي قد تحدث عند تطبيق كل منها على حده، ومقارنتها بغير ها من الإستراتيجيات في مستويات المعرفة المختلفة، ليتم التعرف على إستراتيجيات تدريس جديدة، و التعرف على الاستر اتيجيات التدريسية التي تناسب كل مستوى من المستويات المعرفية على حده، 
و التي تتيح للمتعلمين المشاركة الفاعلة وتزيد تحصيلهم من المعلومات المر اد تعلمها وتشجعهم على التفكير العلمي وترفع من مستويات التفكير العليا؛ وتجعل التعلم يتمركز حول المتعلمين أنفسه. وبالتحديد فإن هذه الدر اسة هدفت إلى: التعرف على أثر استخدام التكامل بين إستر اتيجيتي التعلم التعاوني والتعلم الذاتي متكاملة واستخدام إستر اتيجية المحاضرة المعدلة و استخدام إستراتيجية المحاضرة العادية في تنمية مستوى التحصيل لدى طلاب كلية الثريعة بجامعة الإمام في مقرر المناهج وطرق التدريس، في كل مستوى من المستويات المعرفية وفق تصنيف بلوم.

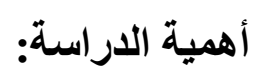

أهمية هذه الدر اسة تأتي من جانبين أهميتها العلمية و أهميتها العملية والتي تتلخص بالتالي: ا ـ الأهمية العلمية: تتبع أهمية الدر اسة العلمية مما يلي: • أن الاستر اتيجيات المختارة في التجربة تعد من أهم الاستر اتيجيات التي تستخدم في التدريس الته الته في الوقت الحاضر، إن لم تكن أهمها وأشهر ها، ومن ذللك كانت أهمية الدر اسة والتجربة. الحاجـة إلى التعـرف على أفضـل الاسـتر اتيجيات و الطـرق المعينـة في التـدريس، وزيـادة في خبر ات المعلمين ورفعا لمستوى الأداء التدريسي، ومو اكبة للعصر ومسايرة للتوجهات العالميـة التي تنادي بتبني استر اتيجيات تدريس حديثة في التذريس وخاصـة في التعليم الجـامعي تضـن جودنه.

المقارنة بين استر اتيجيات حديثة وطرق قديمة و وحاولة للتوليف بين الجديدة والتقليدية و التكامل بينها مسـاهمة في التغلب على سلبيات الطر ائق التقليديـة والأخذ بمـا يتميز بـه كل من الجديد و التقليدي. أهمية الوقوف على معرفة أثر استخدام بعض استر اتيجيات التعلم النشط بعد توليفها ومحاولة التخلص من سلبيتها عند تطبيقها لوحدها، ومقارنتها بغير ها في مستويات المعرفة المختلفة، ليتم التعرف عليها، و استخدم الاستر اتيجيات التدريسية التي تتاسب كل مستوى على حده والتي تتيح للطلاب المشاركة الفاعلة وتزيد من تحصيلهم للمعلومات المر اد تعلمها وتشجعهم على التفكير العلمي و ترفع من مستويات التفكير العليا لديهم، وتجعل التعلم يتمركز حول المتعلمين أنفسهم. فتح المجال أمام الباحثين لإجر اء در اسات حول أثر استر اتيجيات تدريس أخرى و التوليف بينها وفق فلسفة التعلم النشط ونظريات التعلم المختلفة. 


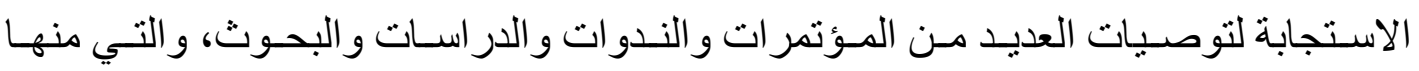

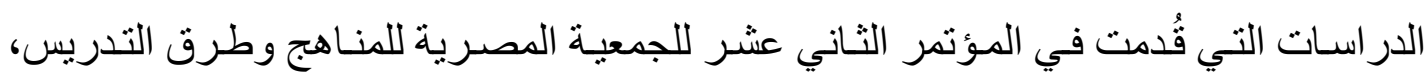

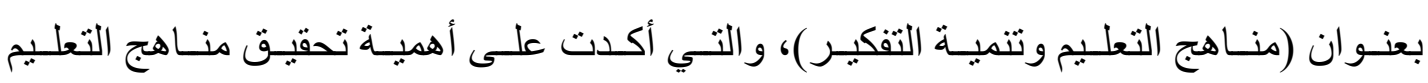

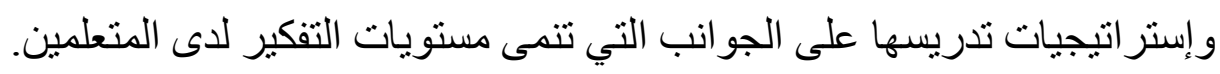

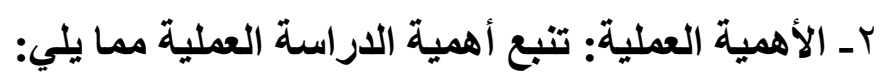
أنها تقام نموذجاً تطبيقياً مقارناً لبعض إستر اتيجيات التعلم النشط مقارنة بإستر اتيجية المحاضرة

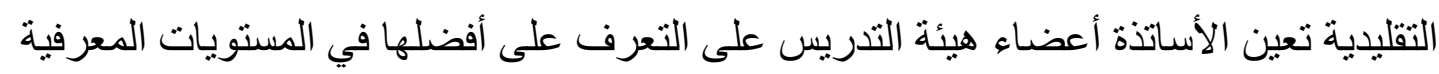

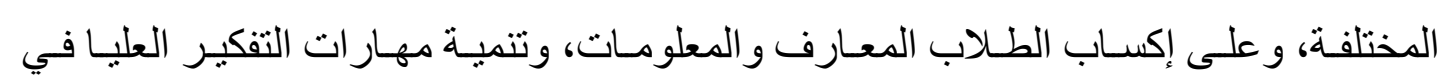
تدريس المقررات الدراسية المختلفة.

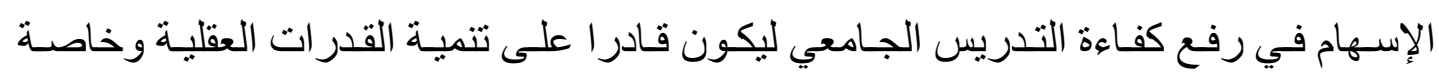

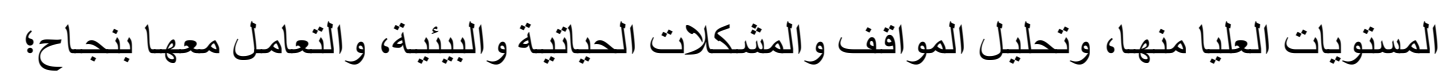
ليصبح التعليم في الجامعـات فـاعلا ويساعد في إعداد المتعلمين للقيام بـأدوار هم ومو اجهة التحديات و المشكلات الحياتية.

فتح آفاق جديدة لتجريب استر اتيجيات أخرى تساعد في تتمية التحصيل ورفع مستوى مهار ات التفكير العلمية وخاصة المستويات العليا منها لدى المتعلمين. حدود الاراسة: تقتصر الدراسة الحالية على:

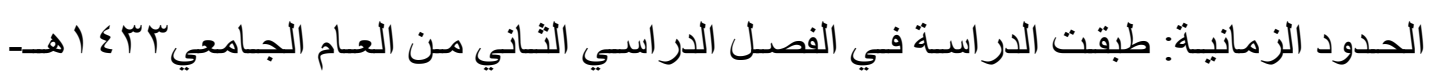
ع الحدود المكانية: اقتصرت الدر اسة على ثلاث شعب من شعب المستوى السـادس (طلاب) في كلية الثريعة بالرياض بجامعة الإمام محمد بن سعود الإسلامية.

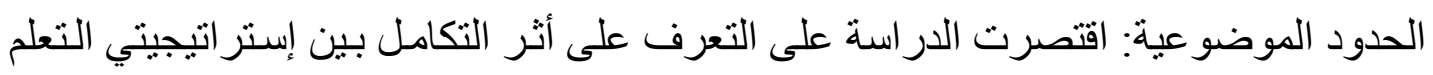

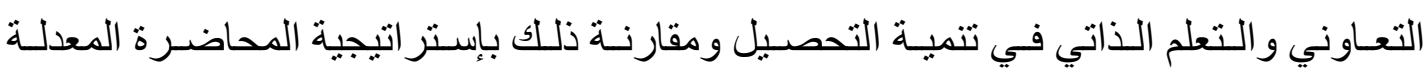

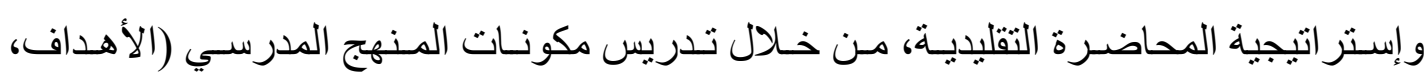
المحتوى، الأنشطة والطرق وتقنيات التعليم، التقويم)، والتي تمثنل القسم الثاني من مفردات مقرر المناهج وطرق التدريس (ترب (ب) )، والذي يدرس في المستوى السـادس و يعد مقررا 
متطلبا لطلاب بعض كليات الجامعة ومنهم طلاب كلية الثريعة بجامعة الإمسام محمد بن سعود الإسلامية.

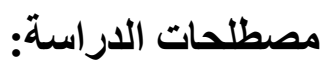

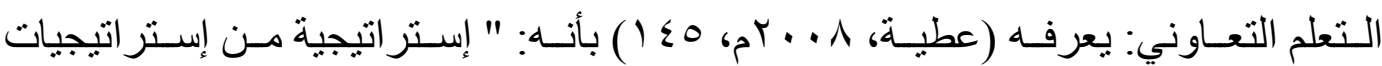
التدريس تقوم على أسـاس التعـاون، وتبـادل المسؤولية في التعلم بين أفر اد المجمو عـة التعاونيـة، و تفاعلهم مع بعضهم، و التكامل فيما بينهم وصو لا إلى التعلم المنشود، و التنافس فيه هو تتافس بين المجمو عات، وليس بين الأفر اد". ويُقصد بالتعلم التعاوني في هذه الدر اسة: بأنه ترتيب الطلاب في مجمو عـات متكافئة يتر اوح عددها بين (ع ـ0) طلاب، وفق صفات تقتضيها الخطة التدريسية وتكليفهم بمفردة من مفردات المقرر يقومسون مجتمعين متعـاونين بإعدادها وتحضير ها وتقديمها على شـر ائح البور بنيت أمسام زملائهم في وقت المحاضرة وفق خطة مرسومة. الاستراتيجات التكاملية: إحدى استر اتيجيات التعلم التعـاوني، حيث يتم تقسيم الطلاب إلى مجمو عات، ويكلف كل طالب في المجمو عة بدر اسة جانب محدد من جو انب موضوع ما، ثم يلتقي الطلاب المكلفون بدر اسة نفس الجانب من الموضوع ويشكلو ا مجمو عة وتسمى (مجموعة الخبر اء) ليناقتـو ا هذه الجزئيـة مـن الموضـوع باستفاضـة، وبعد ذلك يعـود كل و احد منهم إلى مجمو عتهـ الأصلية ويشرح هذا الجان من الموضوع لباقي أفر اد المجموعة وبهذا يتم عرض الموضوع كله في النهاية بين أفر اد المجمو عة الو احدة وهذا يثبه إلى حد كبير اللعاب التي تحتاج إلى تجميع القطع لتصل في النهاية إلى الثكل المطلوب.

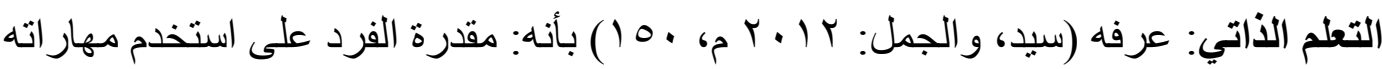
وقدر اته الذاتية في إنجاز عملية التعلم وتحقيق نو اتجها ". ويُقصد بالتعلم الذاتي في هذه الدر اسة: مجموعة من الإجر اءات لإدارة عملية التعلم بحيث يندمج المـتعلم بمفـردة بالقيـام بمهـام تعليميـة تتناسـب مـع قدر اتـه الخاصــة وحاجاتـهـ ومسـتوياته المعرفيـة و العقليـة و المهاريـة، وذلك بـالتخطيط بتوجيـه أسـتاذ المقرر لاختبـار مفردة مـن مفـردات المقرر و إعدادها وتتفيذها.

التعلم النشط: عرفه فيدلر وبرينت (Fedler and Breant، 1997): بأنه " التعلم الذي يعني إثغال المتعلم بشكل مباشر نشط في عملية التعلم ذاتها بمعنى التعلم بالأنشطة التي تتفذ داخل 
الصف، و إذا لم يكن الوضع و الحالة هذه فإن تعلمه يقتصر على استقبال المعلومـة اللفظيـة والمرئيـة

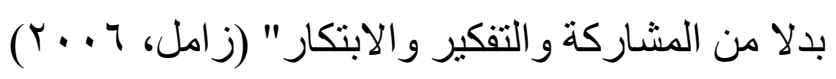

ويقصد بالتعلم النشط في هذه الدر اسة: أنه التعلم الذي يعدل فيـه المتعلم على تكوين المعنى و تحقيق الهدف والتعاون مـع الآخرين وفق بيئة يتم فيها تشـيع المتعلمين بشكل فردي وجماعي على المشاركة في بناء نماذجهم العقلية من المعلومات التي يكتسبونها مع التأكيد على اختبار صدق النماذج الذي قاموا ببنائها، متمثلا ذلك في الاستر اتيجيات التي تم اختيار هـا في هذه الدر اسـة وهي: التعلم الذاتي، و التعلم التعاوني بشكل تكاملي بينهما، و المحاضرة المعدلة. المحاضرة المعدلة: كما يذكر (سعادة، و عقل، وز امل، وشتيه، و أبو عرقوب هدى: ج ج . F م،

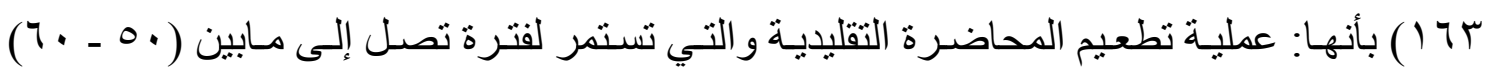
دقيقة، بطرح عدد من الأسئلة ومناقثتها مع الطلبة تعد الخطوة لأولى التي يمكن أخذها في الحسبان لتشنيط المحاضرة أو العمل على تفعيلها وأن تستهل بأنشطة التحفيز الذهني المتعلقة بالقضـايا التي لم يتم حلهـا في المحاضـر ات السـابقة، أو بإعطاء الطلبة فرصـة لطر ح أسئلة حول القراءات التي أنجزو ها أو الفرضيات التي طرحو ها حول بحث أو در اسة، وهنا يمكن للمحاضر التعامل مـع هذه القضـايا و الأسئلة و الفرضيات أثنـاء تقديمـه للموضـوع الجديد، وبذلك يمكن أن يتم تعديل أسلوب المحاضرة القديم و الذي يعد أسلوبا من أسـاليب طريقة الإلقاء بمـا يسمح للمتعلمين بفهم واستيعاب الأفكار الرئيسة للعرض وذلك بتطعيمها ببعض الأسئلة و المناقثـات، و الممارسـات التي يمكن من خلالها جعل التعلم نشطاً، ومن ذلك:

السماح للمتعلمين بالتأمل في ما بدور من أفكار رئيسة، كأن يسأل المحاضر ما الأفكار الرئيسـة التي تم تعلمها؟ ما الأفكار التي تقترح إضـافتها لتحقيق أهداف التعلم؟ وهذا مـا يؤكد عليه التعلم النشط بأن يسهم المتعلم من خلاله في رسم أهداف تعلمه بنفسه. تقسيم المحاضـرة إلـى جـز أين يتخلاهمـا مناقثــات في مجمو عـات صــيرة حـول موضـوع المحاضرة فيمارس الطلاب من خلال التفاوض مع أقر انهم و أستاذهم بناء التعلم.

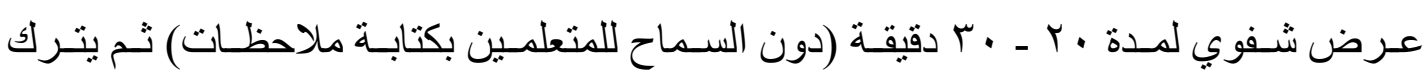
للمتعلمين خمس دقائق لكتابة ما تعلموه في هذه المحاضرة، ثم يوزعون في الوقت المتبقي في مجمو عات للتأمل ومناقتنة ما تعلموه. 
ويُقصد بالمحاضـرة المعدلة في هذه الدر اسـة: بأنها مجمو عـة من الإجر اءات لإدارة عملية التعلم يتولى المعلم فيها عرض موضـوع معين بأسلوب شفهي يلانُم مستويات المتعلمين من أجل تحقيق أهداف الدرس، ويلتزم فيها بالإعداد المسبق والتدرج والتوازن في العـرض، والتوقف المخطط أثناءهـا و إثـارة الأسـئلة وحريـة المناقثــة المنظمـة، واسـتخدام الوسـائل وتقنيـات التعليم، و التقويم و المتابعة كلما كان ذلك ممكنا و محققا للأهداف.

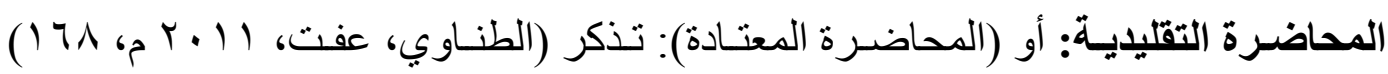
بأنها: " قيام المعلم بإلقاء المعلومات المتضمنة بالدرس على المتعلمين ليقوموا باستيعابها وحفظها، مستخدما في ذللك أسلوب الكلام طو ال وقت الحصة مع الاستعانة أحيانا بالسبورة في أثناء الثرح. ويُقصد بالمحاضرة التقليدية أو المحاضرة في هذه الدر اسـة: بأنها استخدام المعلم الأسلوب الثـفهي لعـرض موضـوع معين يلتزم فيـه بالإعداد المسبق و التـدرج و التـوازن ويلائم مسـتويات المتعلمين ويحقق أهداف الدرس؛ مستخدماً في ذللك أسلوب الكلام طو ال وقت الحصـة مـع الاستعانة أحيانـا بالسـبورة أثنـاء الثـرح وتوجيـه بعضض الأسـئلة للمتعلمـين، و علـيهم أن يقومـوا باسـتيعابها

وحفظها.

التعلم النشط (ماهيته واستراتيجياته):

إن التسارع الكبير و التطورات المتلاحقة في مجالات المعرفة والعلم وتقنياتهما فرض تحديات كثيرة على الجميع جعلت الأفراد يتلمسون احتياجاتهم بينها وفرضت عليهم ضرورة الأخذ بقدر منها وإعادة النظر في طرق التفكير لكي يعايشوا ويوظفوا هذه المتغيرات المتسارعة ويواكبوا العصر، لكن ذلك يجب أن يتم مع المحافظة على الثوابت والقيم والانتماء، ومناهج التعليم معنية بشكل مباشر في تلمس الاحتياجات ومو اكبة المستجدات والأخذ بالنظرة الحديثة للعلم وأنه ليس مجرد نتاج معرفي فقط و إنما عمليات بحث واستقصاء بطرق علمية توصل إلى المعرفة وتدركها وتأخذ بالجديد منها وتوظيفه بما يحقق نو اتج تعلم أفضل. وبالنظر لذلك فإن البحث في الإستراتيجيات الحديثة للتعليم والتدريس والتعلم بات أمرا ضروريا، حيث تؤكد الدراسات على أهمية استخدام الإستر اتيجيات الحديثة التي تركز على إيجابية المتعلمين ونشاطهم وتجعلهم محور العملية التعليمية، لللك فإن المتخصصين في مجال المناهج وطرق التدريس " يسعون إلى التوصل إلى إستراتيجيات وطرق وأساليب تساعد المعلم على إدارة

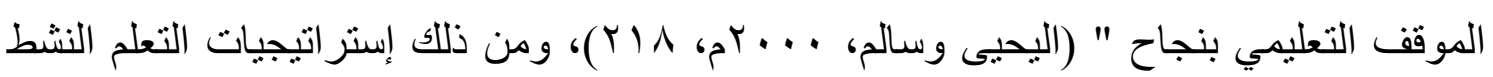


و التي تتلخص أهميتها في رفع مستوى التحصيل وتطوير قدرة المتعلمين، وتجعل اتجاهاتهم إيجابية نحو التعلم من خلال المقررات التي يتعلمونها، وتنمى قدراتهم على مهار ات التفكير العليا والتفكير الناقد، و على استخدام ما تعلموه وتطبيقه في مجالات الحياة المختلفة، ومن تللك الإستر اتيجيات التعلم التعاوني، و التعلم الذاتي، و المحاضرة المعدلة، وسيتناولها الباحث هنا بثيء من الاختصار:

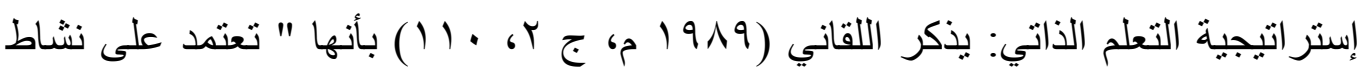
المتعلم بمجهوده الذاتي الذي يتو افق مع سر عته وقدر اته الخاصة مستخدما في ذلك ما أسفرت عنه التكنولوجيا من مو اد مبرمجة، ووسائل تعليمية، وأشرطة فيدو وبر امج تلفزيونية ومسجلات، وذلك ولك لتحقيق مستويات أفضل من النماء والارتقاء لتحقيق أهداف تربوية منشودة "، ويمكن القول بأنه ذللك النوع من التعلم الذي يتحقق نتيجة لتعليم الفرد نفسه بنفسه من مصادر التعلم المختلفة، واستخدامها كإستر اتيجية تدريسية في المجال الصفي يُقصد بها مجموعة من الإجراءات لإدارة عملية التعلم بحيث يندمج المتعلم بمفردة بالقيام بمهام تعليمية تتناسب مع قدر اته الخاصة وحاجاته ومستوياته المعرفية و العقلية والمهارية، بشكل مخطط من المعلم وبتوجيهه و إثر افه، كأن يكلف المتعلم باختيار مفردة من مفردات المقرر وإعدادها و إرسالها لبريد المعلم فتنفيذها أمام المتعلمين و تعديلها وإرسالها إلكترونيا لموقع مجموعة التعلم، أو غيره مما يحقق الأهداف الخاصة للمحاضرة ويزيد من النواتج التعليمية، وهذا النوع من التعلم تؤكد أهميته البحوث النفسية والتربوية وتعده طريقة لإدارة عملية التعليم والتعلم وتنظيمها بحيث يندمج المتعلم في نشاطات تعليمية تناسب

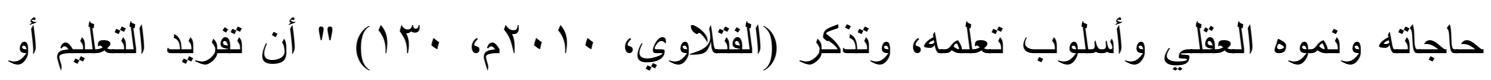
الاهتمام بالمتعلمين أفر ادا لهم خصوصياتهم لم يكن وليد تطور تربوي معين أو فترة زمنية معينة

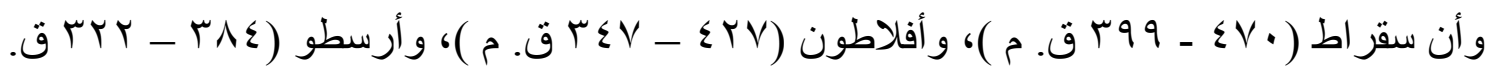
م) اهتموا بالفروق الفردية وبضرورة التركيز على قدرات المتعلم باعتباره شخصية متميزة، وأن التعليم الفردي استخدم في التربية الإسلامية حيث ركز المربون المسلمون على العناية بكل متعلم وفق قدر اته و استعداداته، كما وأن المتعلم النابغ لا يتعلم بالأسلوب وبالمو اد الدر اسية التي يتعلم بها الآخرون.

إستر اتيجية التعلم التعاوني: " تعرف بأنها استر اتيجية تدريس تعتمد على مبدأ تعلم الطلاب

في الصف لموضوع در اسي معين في صورة مجموعات تعاونية صغيرة بغية تحقيق أهداف

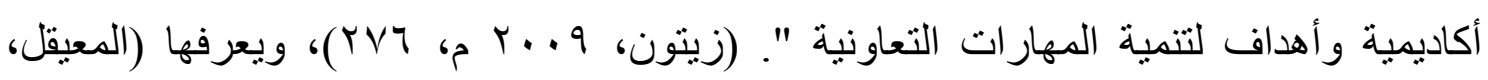




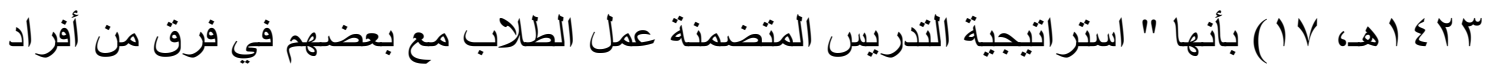
بخلفيات متنوعة؛ من أجل إنجاز مهامات وأنشطة تعليمية مخططة ومنفذة تحت إثر اف وقيادة

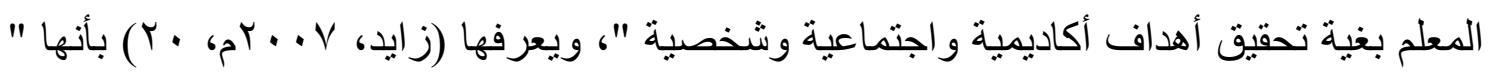
إيجاد هيكلة تنظيمية لعمل مجموعة التلاميذ بحيث ينغمس كل أعضاء المجموعة في التعلم وفق أدوار واضحة محدة، مع تأكيد أن كل عضو في المجموعة يتعلم المادة العلمية "، ويذكر (لويد

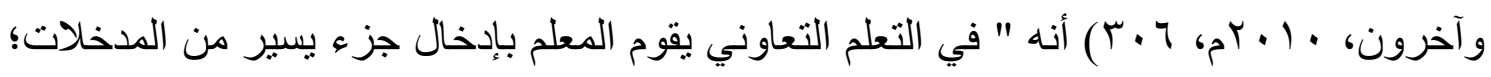
أي المادة المطلوب تعلمها، ويقابل ذللك جزء ضخم أكبر بكثير من حرية الطالب لأن يستكثف التعلم بنفسه؛ أي أن المعلم يحدد المهمة المطلوبة ويوضحها، ولكن المجموعة هي التي تقرر كيفية البحث عن الذي يقوم به الميسّر، إن هدف العمل التعاوني هو أن تتعلم من خلال التعاون والتفاعل و الإنجاز لما تكلف به من مهام مع غيرك "، و التشارك و التعاون من عو امل النجاح حيث يقول (د.

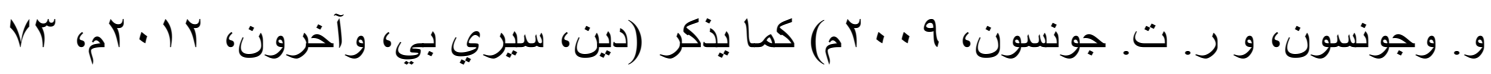
): " ويساعد التعلم التعاوني على إرساء النجاح للطلاب في عالم يعتمد على التشارك و التعاون "؛ ولن تجد سوى إستر اتيجيات قليلة تحظى بمثل الأساس النظري الذي يحظى به التعلم التعاوني "، ويمكن أن يتخذ التعلم التعاوني عدة أنثكال من مثل عمل الفريق حيث يتم تقسيم العمل وحيث يجري التعلم من الأقران مما يسهم في تعلم كامل أفراد المجموعة وهذا بدوره يساهم في إنجاز المشروع من كامل الأفراد ، ومع ذللك فهو من أكثر الممارسات الصفية التي أسيء فهمها (انتل، جنكنز،

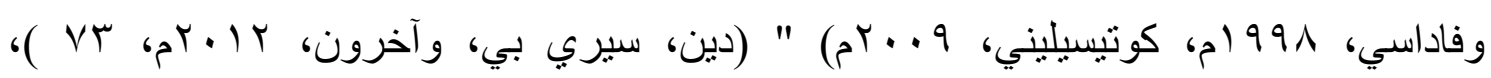
و تطبيقها وينبع بعض اللبس الذي يكتنف تطبيق استر اتيجية التعلم التعاوني من الطرق المختلفة التي يعر فه المختصون بها، ومن ثم بنعكس ذللك على تطبيقه في قاعات الدرس، لذا كان من المهم رصد عناصر تعريفه، ف (فجنسون، وجنسون، 999 (م) كما يذكر (دين، سيري بي، وآخرون، Y I ب Y، ع V يحددان خمسة عناصر لتعريفه هي: الاعتماد المتبادل الإيجابي، والتفاعل المشجع وجها لوجه، والمحاسبية الفردية ومحاسبية المجموعة، والمهار ات بين الشخصية ومهار ات المجموعة الصغيرة، ومعالجة المجمو عة، ويمكن بيان هذه العناصر الخمسة وفق الجدول (1): 
جدول ( ) يبين أنموذج عناصر التعلم التعاوني

\begin{tabular}{|c|c|c|}
\hline المتضمن التدريسي & الهذف & العنصر \\
\hline 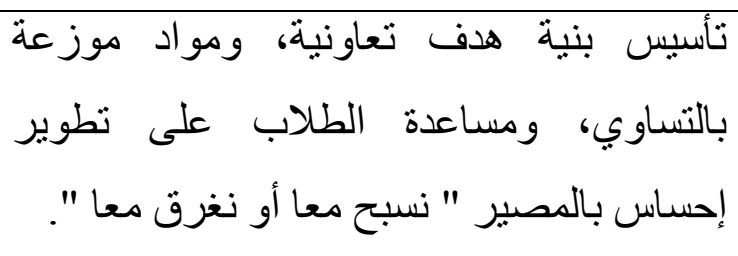 & أعضاء المجمو عة الآخرين. & الإليجابي. \\
\hline الثتجيع المناقثة بين أعضاء الهجموعة، وتعليم & ليلإنجاز ، ويساعدون بعضهر على الأفراد وينشطون الجهود & وجاعل التشجيع \\
\hline تأسيس حجم مجموعة أمثل، واستخدام تقويمات للإسل مساعدة الطلاب على فهم حاجة كل & 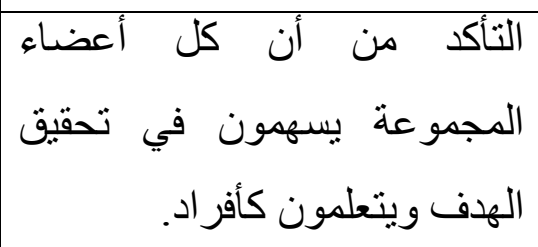 & و والمجموعية الفرد. \\
\hline 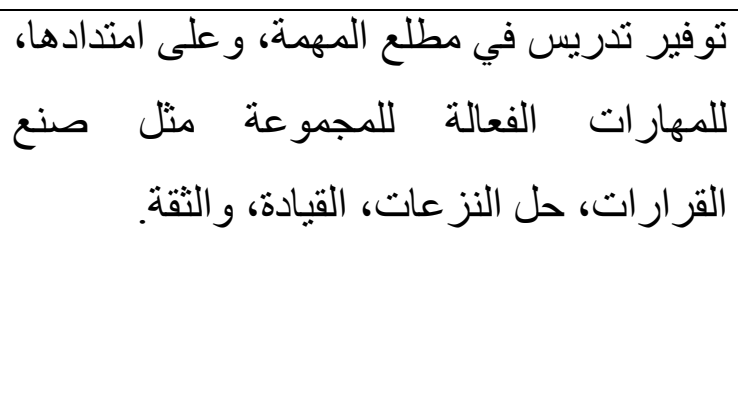 & 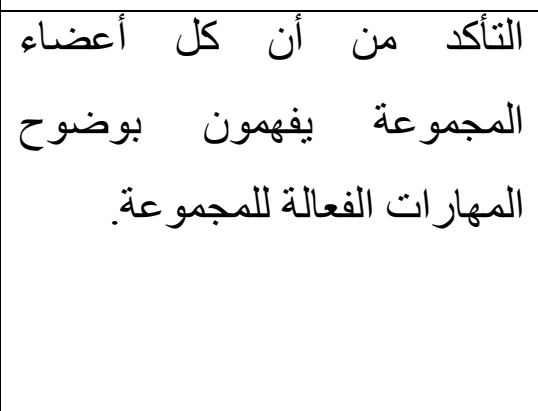 & شهار الصهية \\
\hline 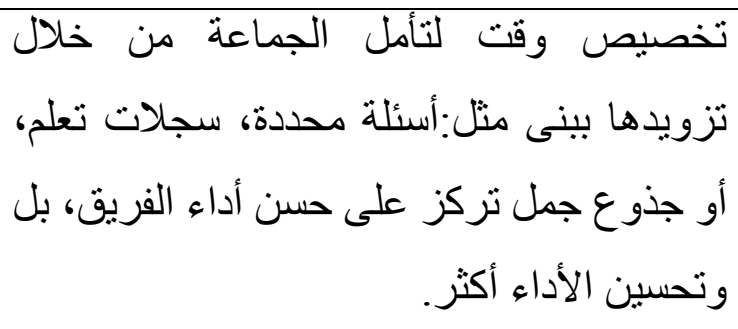 & 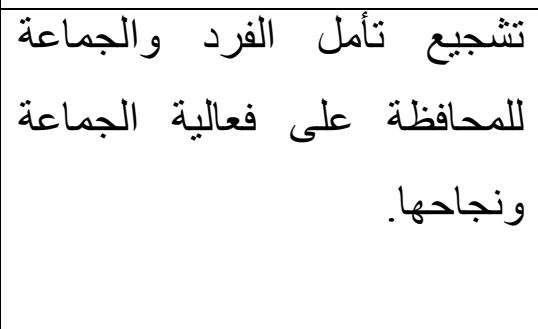 & معالجة \\
\hline
\end{tabular}

ويؤكد باحثون وممارسون آخرون بأن التعلم التعاوني استراتيجية تستخدم - بصورة عامة -

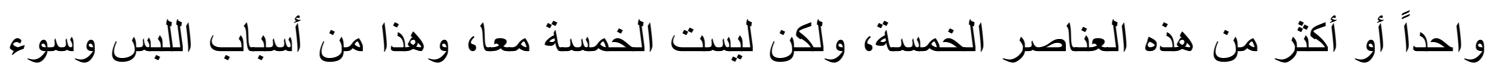

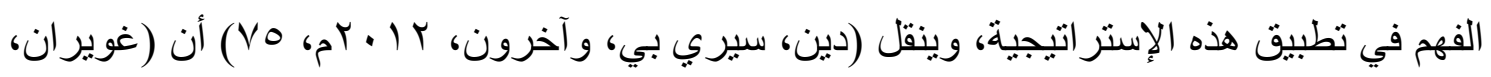

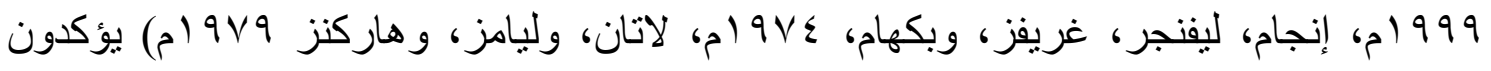

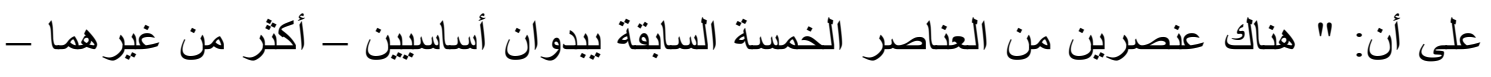

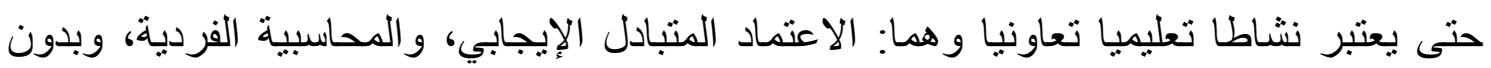


هذين العنصرين، فإن بنى تعلم المجموعة يمكن أن تعوق - في الواقع - عملية التعلم "، لكن يجب أن يوفر التعلم التعاوني للطلاب فرصا كي بتفاعلو ا بطرف تستحث تعلمهم وتعمقه، لكونه يقوم على زيادة التعلم من خلال تفاعل اجتماعي قصدي حسن التصميم، وكذلك يوفر بيئة صفية يستطيع الطلاب فيها التأمل في خبراتهم المكتسبة حديثا، ومعالجة ما تعلموه من خلال التحدث و الاستماع الفاعل لأقرانهم وتطوير فهم مشترك حول موضو عات التعلم، وهذا يساعدهم على الاحتفاظ بما تعلموه، ويزيد من دافعيتهم نحو التعلم، ويقوي عندهم آصرة الترابط و الالتز ام تجاه بعضهم، وهذا يفضي إلى مشاركة فاعلة وزيادة في الإنتاج وسرعة في الإنجاز، كل ذلك يتم عند رسم الأهداف بشكل مدروس، وتحديد الأدوار والمهام بصورة فاعلة، فكل يعرف دوره وير اعي الجميع المواعيد المحددة لإنجاز المهام بشكل تشاركي، لكن ذلك يجب أن يكون دون تفريط، فالطلاب يحتاجون لوقت كاف كي يمارسوا فرديا المهارة والعملية التي سيتمكنون منها، ويتم استخدام التقنيات في التعليم التعاوني بما بضمن الاعتماد المتبادل وكذلك محاسبة الفرد و المجمو عة، وتظهر الدراسات كما يذكر (بيسلي، وآبثورب، · ( • r ) ): أن فرص التعلم التعاوني - ذات التنظيم الجيد - تؤثز إيجابا على الإنجاز الأكاديمي، وكذلك على التكيف النفسي الاجتماعي، وتقدير الذات، والدافعية، و الانخر اط في المدرسة، وتقلل - في الوقت ذاته ـ من مثاعر العزلة الاجتماعية، وتوفر للطلاب فرصا للتعلم و القيادة في المجمو عات التعاونية، وتساعدهم على تطوير المهار ات الأساسية اللازمة

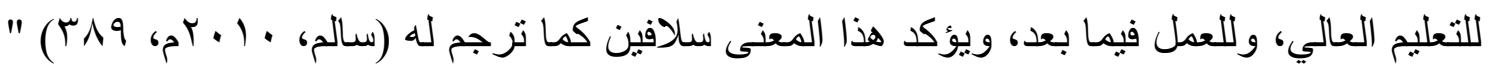
إن أحد أكبر فو ائد التعلم التعاوني تتمثل في رفع مستوى تقدير الذات وببساطة يتعلم الطلاب أن لهم قيمة و أنهم مهمون وبهذا يرتفع مستوى تقدير الذات لايهم بسبب شعور هم بقيمتهم لدى أقرانهم وبسبب شعور هم بأنهم يحققون انجاز ات بالمعنى الدر اسي وبالفعل إن الطلاب ينجزون بشكل أكبر في الفصول التعاونية مما ينجزون في الفصول التقليدية ". ويتميز التعلم التعاوني عن التقليدي بعدد من الخصائص من أبرزها كما تذكر (زبيدة قرني،

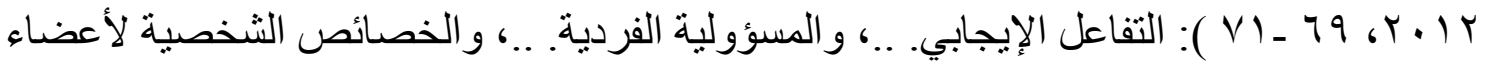
المجموعة. ..، وقيادة المجموعة. ..، والتدعيم والتشجيع. ..، وتنمية المهار ات الاجتماعية. ..؛ و تقييم المجمو عة: أن على المجموعة تقييم أدائها ومناقثة مدى تحقق الأهداف، وبإمكان المتعلمين أن يبينوا هذه التقييمات خلال نقاش صغير أو بتزويد المعلم بتقارير مكتوبة عن تقدمهم، ويجدر

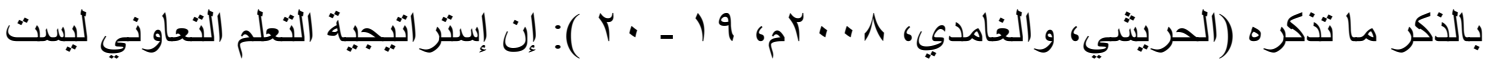


جديدة، فجذور هذه الإستر اتيجية التي تؤكد على التعاون والتآزر و التضامن إسلامية، يجب أن نؤكد عليها ونحتفظ بحق السبق إليها، حيث نبه إليها القرآن الكريم في أكثر من موضع. ..، ووردت في السنة النبوية. ..، وتجسد التعاون في الدروس التي نظمها الصحابة والمسلمون الأوائل في المساجد على هيئة حلقات تعليمية اعتمدت جوهر التعلم التعاوني الذي ينادي به المربون الغربيون يومنا

المحاضرة التقليدية (العادية): تعد من أوائل الطرائق المستخدمة في التدريس، وتعتمد على

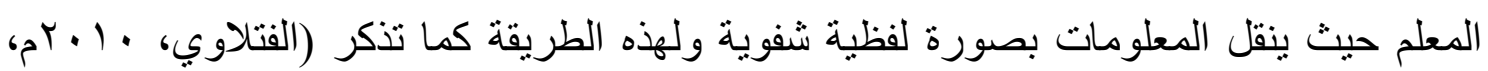
r9) " تسميات عدة، فتسمى الطريقة التفسيرية أو التقليدية أو الإخبارية، وحينا بالمحاضرة، وتقوم أساسا على مبدأ الإلقاء المباشر و الثرح أو التوضيح أو العرض النظري للمادة من جانب المعلم أما المتعلم فهو مستمع لما يلقيه المعلم من مادة علمية "، وتعد المحاضرة نموذجا تقليديا للتدريس الجامعي حيث يذكر (إكسلي، دينيك، 9 . . بام، ( ) ذلك بقولهما: " تعد المحاضرة التي تقدم لمئات الطلاب في قاعة المحاضرات، نموذجا تقليديا للتدريس الجامعي، حيث بسمى أعضاء هيئة التدريس في بريطانيا محاضرين ( Lecturers) وهو مصطلح مشتق من المفردة اللاتينية (Lecture) عملية التدوين من المهام الرئيسة في محاضر ات التعليم العالي "، فغالبا ما ينظر للمحاضرة على أنها مثال للتعليم بالتلقين و الذي لا يتفاعل الطلاب من خلاله سوى بالاستماع وتسجيل الملاحظات، ويؤكد الكثير من التربويين على أن طريقة المحاضرة هي الثنائعة في التدريس لمستويات التعليم المختلفة، وقد اتفقت نتائج العديد من الدر اسات مع تللك التأكيدات منها در اسة محمد (9 9 (م) و التي

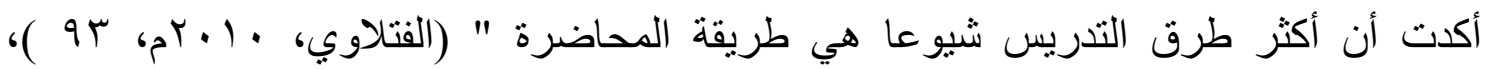
فالمحاضرة " تعتبر إحدى الطرق التي يستخدم فيها الجانب النظري من سلوك المعلم لتحقيق الأهداف المطلوبة، وتكون فيها عملية الاتصال في معظم الأحيان من المعلم إلى المتعلم الذي يتلقى ما نقل إليه من معلومات، ولكي يقوم المعلم باستخدام طريقة المحاضرة، فإن هنالك خطو ات مرتبة يمكن أن يتبعها وهي: تحديد موضوع المحاضرة والغرض منها وما تحتويه من نقاط فرعية ومصطلحات، ثم شرح النقاط الفر عية و الربط بينها وإظهار ما بينها من علاقات، وحل ما قد ينشأ من اعتر اضات من جانب المتعلمين والإجابة على أسئلتهم، ثم تلخيص النقاط و الأفكار التي جاءت

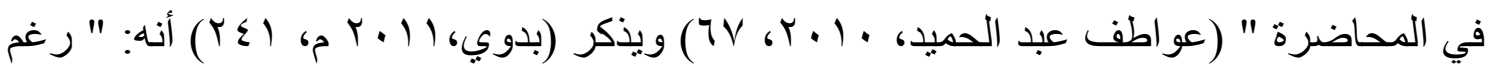


أن مصطلح المحاضرة يستخدم عادة في سياق التعليم الجامعي والتدريب فإننا نأخذه على أنه يغطي

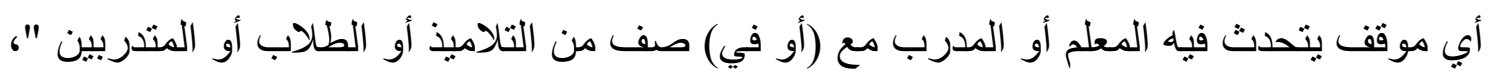

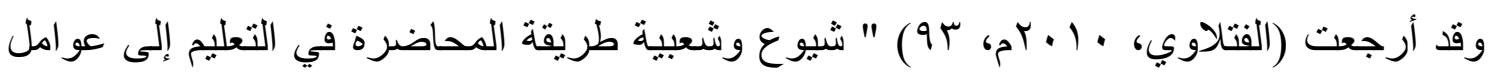

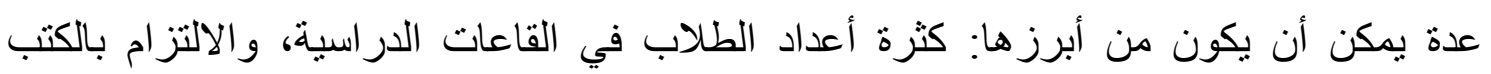
المنهجية، أكثر ضبطا للصف، وجود مفردات تقليدية، ضعف رنبة رغبة الطلاب بالمشاركة في عملية التعليم و التعلم "، وقد يضاف إلى ذللك ضيق وقت المحاضرة إذا ما ربط بتوصيف للمقرر ومفرداته المطلوب إنجاز ها خلال وقت محدد، لكن من مز ايا المحاضرة أنها تساعد على تغطية حجم كبير

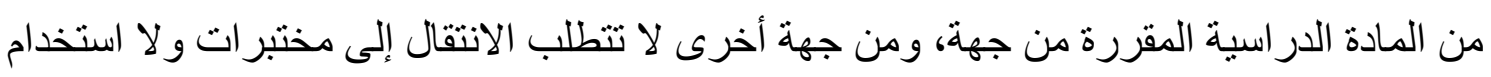

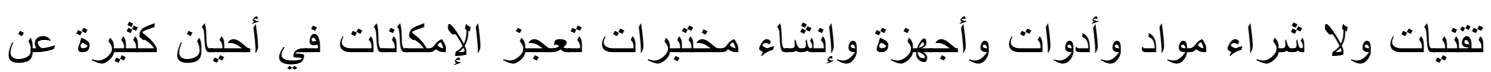

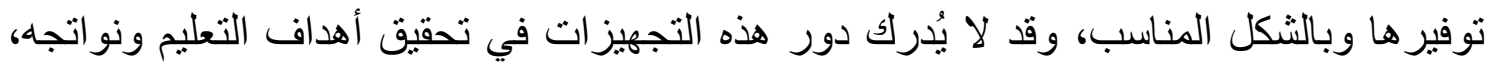

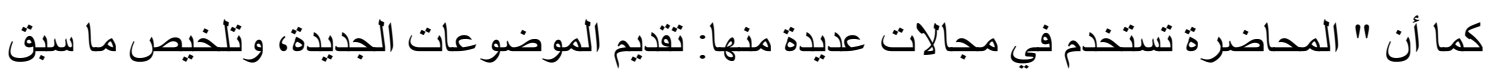
تعلمه، وتوجيه و إرشاد المتعلم إلى مصادر المعرفة، وتوضيح أداء عمل أو مهارة لفظيا، وتوضيح

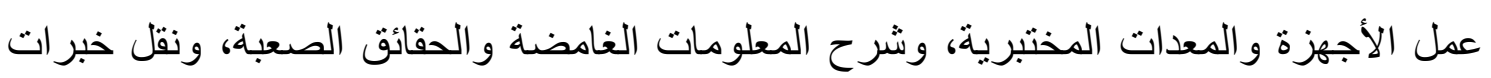
المعلم إلى المتعلم فيضيف خبرات ومعلومات فضلا عن المعلومات المحددة في الكتب المقررة،

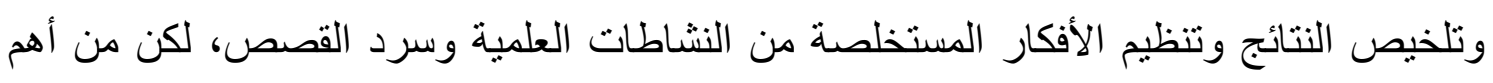

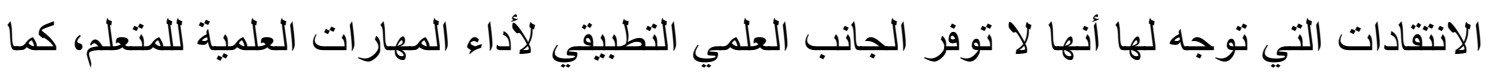

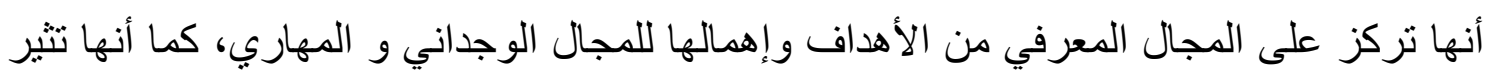
الملل في نفوس المتعلمين نتيجة تمادي المعلم في استخدامها، فضلا عن حرمان الهان المتعلم من الدور

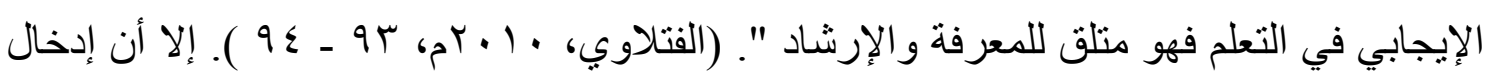

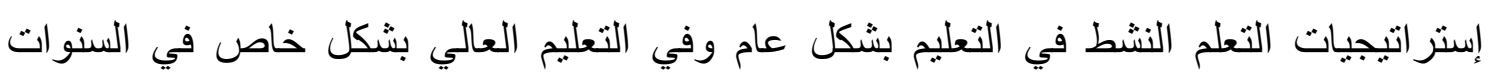

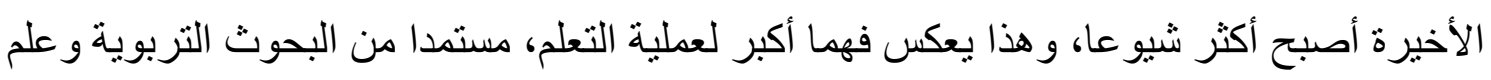

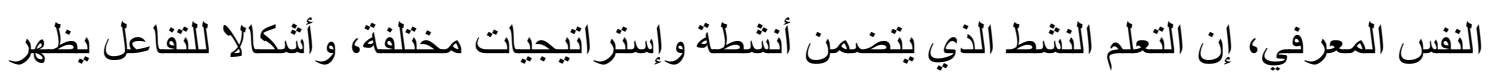

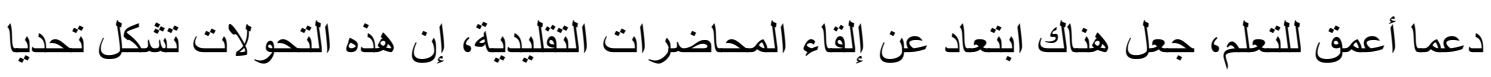

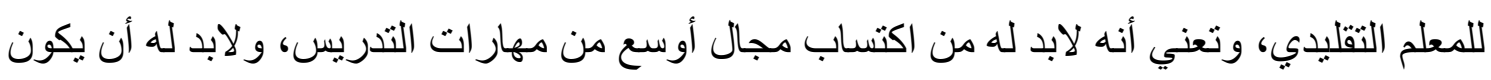

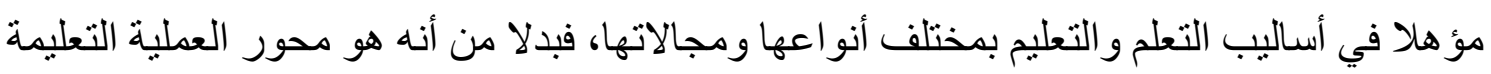

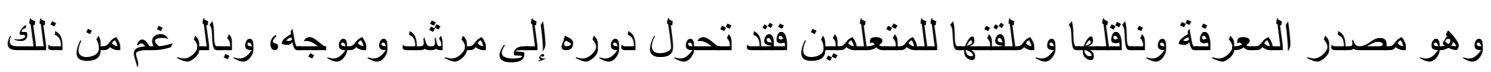




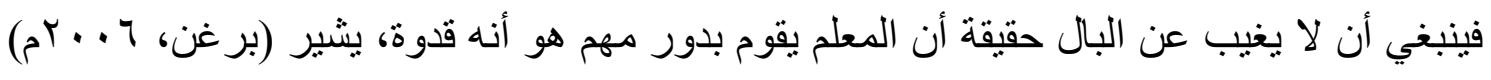

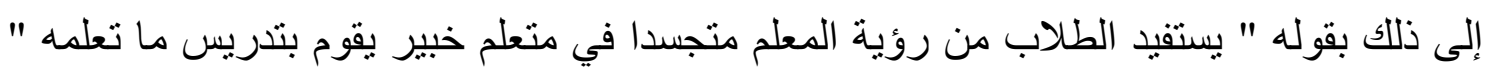

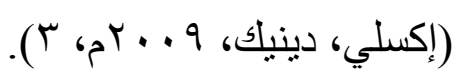

إن الدحاضر الخبير الذي يعرض مفاهيم مهمة من المعارف الحديثة بطريقة محفزة ومشوقة،

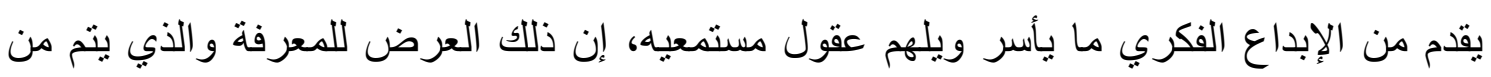
خلال الثرح، هو بحد ذاته تجربة تعليمية قيمة لكل طلاب التعليم العالي، ويرى (إكسلي، دينيك، ولئه

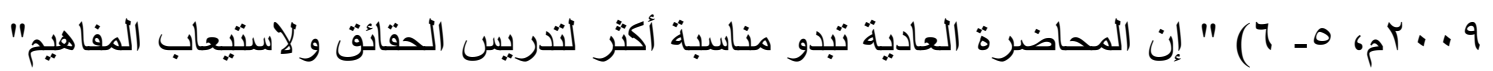
لكنه يذكر: " أن بعض المعلمين قد يجادل بأنه يمكن تدريس مهارات التطبيق والاستخدام أو

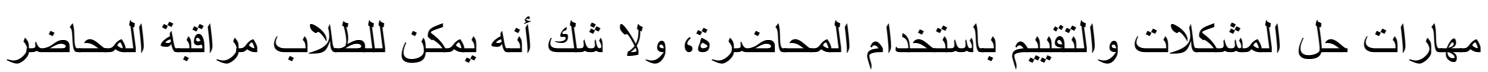

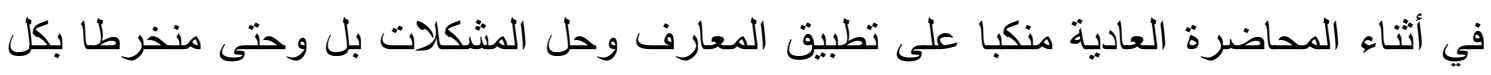

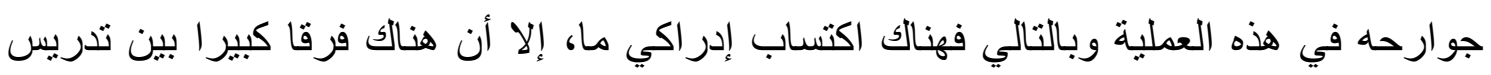
تطبيق المعارف وحل المشكلات وتطبيق الطلاب لذلك بأنفسهم، فتلك المهار ات يمكن دعمها أكثر من خلال تدريس مجمو عات صغيرة من المتعلمين.

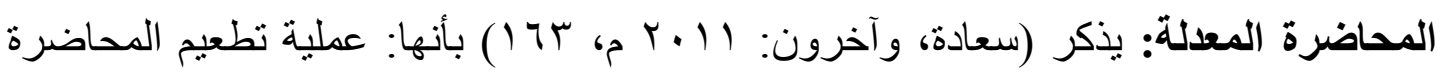

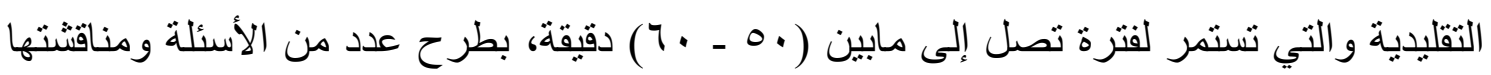

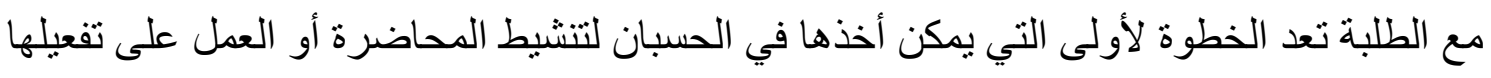

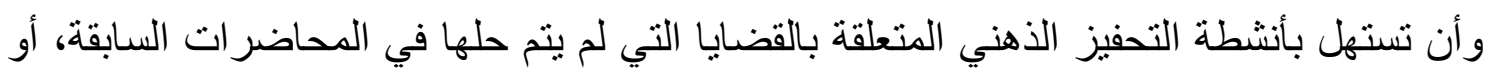

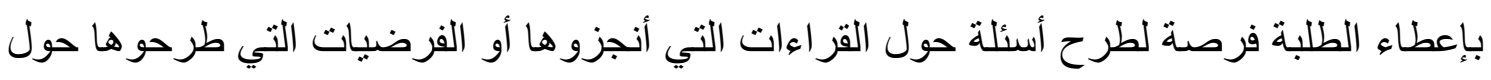
بحث أو دراسة، وهنا يمكن للمحاضر التعامل مع هذه القضايا والأسئلة والفرضيات أنثاء تقديمه

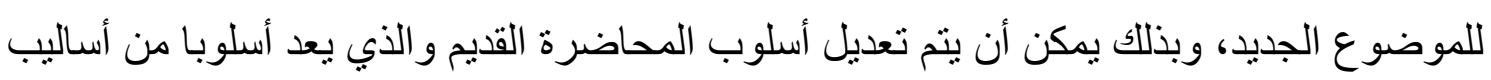

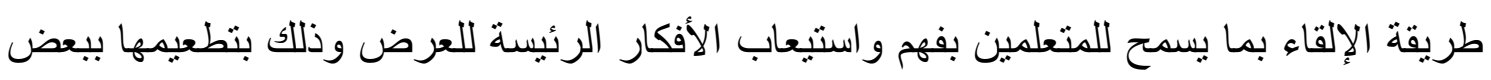
الأسئلة و المناقثات، و الممارسات التي يمكن من خلالها جعل التعلم نشطاً، ومن ذلك:

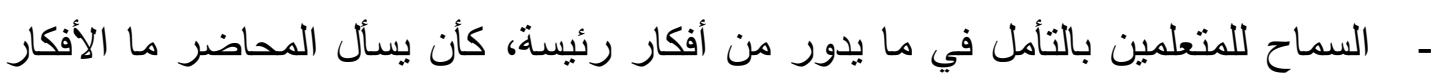

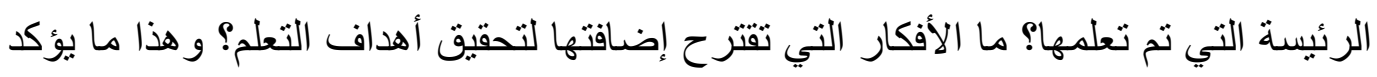
عليه التعلم النشط بأن يسهم المتعلم من خلاله في رسم أهداف تعلمه بنفساه. 
- تقيم المحاضرة إلى جزأين بتخلاهما مناقتشات في مجموعات صغيرة حول موضوع المحاضرة فيمارس الطلاب من خلال التفاوض مع أقر انهم و أستاذهم بناء التعلم. - عرض شفوي لمدة 20 - 30 دقيقة (دون السماح للمتعلمين بكتابة ملاحظات) ثم يترك للمتعلمين خمس دقائق لكتابة ما تعلموه في هذه المحاضرة، ثم يوزعون في الوقت المتبقي في مجمو عات للتأمل ومناقتة ما تعلموه. وبهذا يمكن تنشيط المحاضرة التقليدية وجعلها استر اتيجية من إستر اتيجيات التعلم النشط يؤكد هذا

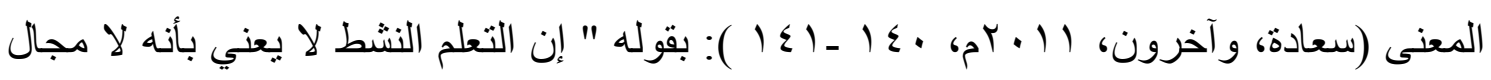
للمعلم كي يستخدم المحاضرة مع الطلاب داخل الحجرة الدر اسية، فالمحاضرة من بين أكثر الطرق شيو عا في إيصال المعلومات إلى الطلاب أو الحضور، وأن الثيء الأساس للمحاضرة في التعلم النشط يتمثل في شد انتباه الطلاب عن طريق التتويع في طر ائق التدريس المستخدمة، وطرح الأمثلة، واستخدام الوسائل التعليمية المتنوعة، وربط موضوع المحاضرة بحياة الطلاب اليومية، كما ينبخي التركيز على أن المحاضرة ليست الطريقة الوحيدة لتوصيل المعلومات إلى الطلاب الذين يتعلمون أصلا بطرق تعليمية مختلفة داخل الحجرة الدراسية الواحدة "، ومن هنا فإن مجموعة من الإجر اءات لإدارة عملية التعلم داخل الصف التي بتولى المعلم فيها عرض موضوع معين بأسلوب شفهي يلائم مستويات المتعمين من أجل تحقيق أهداف الدرس، ويلتزم فيها بالإعداد المسبق و التدرج و التوازن في العرض، والتوقف المخطط أثناءها و إثارة الأسئلة وحرية المناقنتة المنظمة، و استخدام الوسائل وتقنيات التعليم، و التقويم والمتابعة كلما كان ذلك ممكنا ومحققا للأهداف، يمكن أن يعد ذلك تعلما نشطا ويكون تعديلا على المحاضرة التقليدية بما ينشطها ويخلصها أو يقلل من

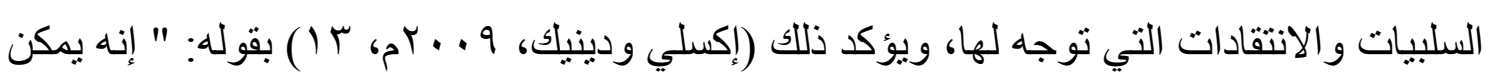
توسيع نطاق المحاضرة باستخدام أساليب التعلم النشط وبتشجيع الطلاب للاندماج تفاعليا مع المقرر الدر اسي ومع المحاضر ومع بعضهم البعض في قاعة المحاضرة، حيث لا تزال المحاضرة حجر أساس في العديد من مقررات التعليم العالي، ومن المرجح أن تبقى كذلك نظرا لتزايد أعداد الطلاب، ليس من الضروري أن تكون محددة من ناحية إمكانيات التعلم كما يصفها بعض الباحثين أمثال بلاي، بل من الممكن من خلال المزج بين أشكال التدريس المختلفة نقل استراتيجيات التدريس الأكثر تفاعلا ومنطقية لقاعة المحاضرات وتوسيع النطاق لإمكانيات تعلم أكبر في

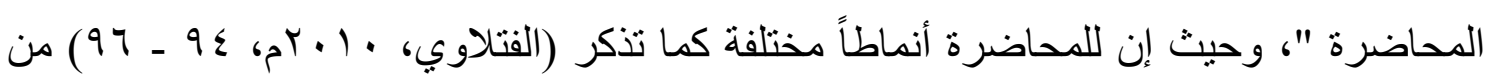


بينها: اــ المحاضرة (الرسمية) المباشرة أو اللفظية المجردة. ؟ـ المحاضرة المدعمة بالوسائل التعليمية.

rـ المحاضرة العرض التوضيحي(التعليمي) ــ المحاضرة الإلقاء مع استخدام السبورة.

$$
\begin{aligned}
& \text { 0ـ المحاضرة - السؤال. المحاضرة ـ النقاش. }
\end{aligned}
$$

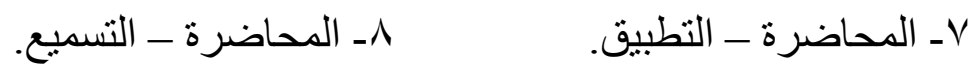

$$
\begin{aligned}
& 9 \text { ـ المحاضرة بأسلوب أخذ الملاحظات المنظمة. }
\end{aligned}
$$

و يمكن أن تستخدم هذه الأنماط مجتمعة أو منفردة بحسب الحال وبحسب ما يضمن تحقيق الأهداف، بل إنه يمكن استخدام العديد من الاستراتيجيات الأخرى بجانب هذه الأنماط والتي تساعد في بناء بيئة تعلم نشط، لكن المدى الذي بستطيع فيه المحاضر الناجح إدخال تغيير على أساليبه

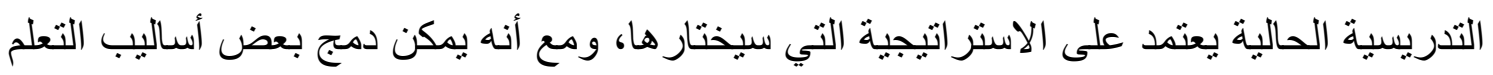

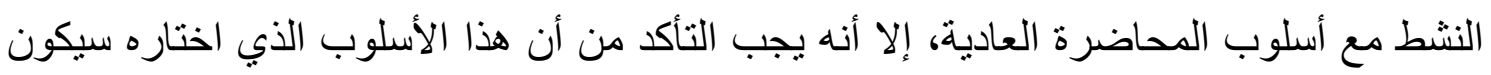

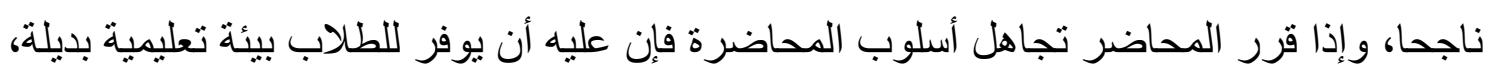
ومع ذلك فإن هناك مجموعة من استراتجيات التعلم النشط المفيدة للمحاضر في تفعيل محاضرته

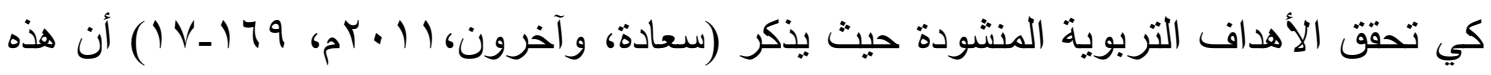

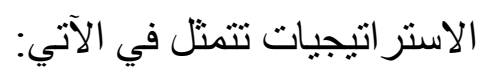
اـ استر اتيجية طرح الأسئلة وأسلوب المحاضرة. بـ استراتجية العصف الذهني وأسلوب

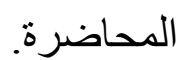
rـ الاختبار ات الطويلة والامتحانات القصيرة وأسلوب المحاضرة. عـ ــدريس الأقران وأسلوب المحاضرة. ــ استخدام تقنية النقطة الأكثر غموضا أو تشويشا في المحاضرة.

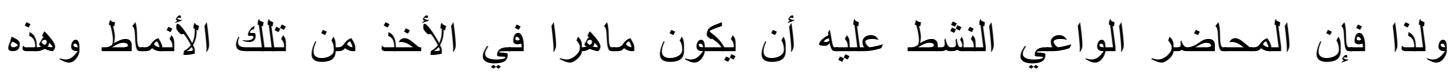

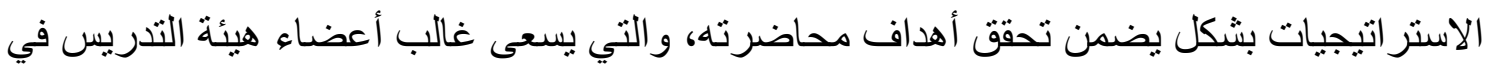

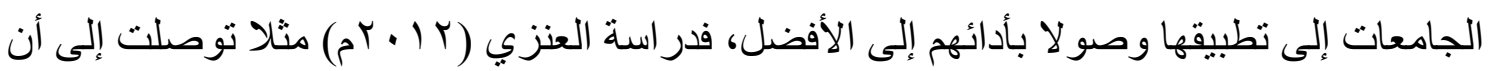
أعضاء هيئة التنريس يمارسون إستراتيجية المحاضرة المعدلة بدرجة فاقت كل الاستراتيجيات

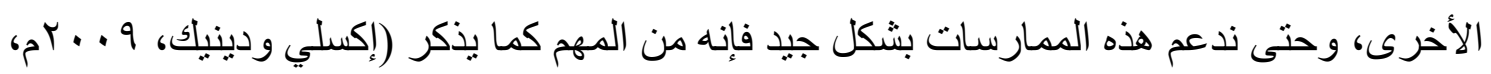

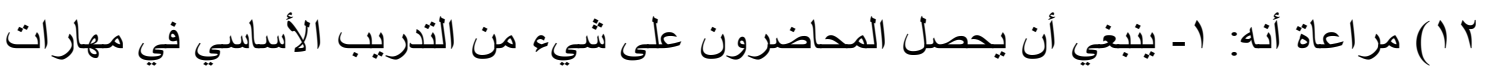


التدريس والتقديم، كما يجب أن يتحلوا بالكفاءة في استخدام وسائل التدريس السمعية والبصرية المختلفة.

ץ- ينبغي أن يكونوا قادرين على تنظيم ونرتيب المحاضرة وأن يتمتعوا بوعي كاف بفن إدارة الوقت.

"ז- ينبغي أن يظهر المحاضرون الحماس لتخصصهم، وأن يوصلو ا هذا الحماس لطلابهم من خلال العرض المشوق و المحفز. و هن هنا فإن قدرة أعضاء هيئة التدريس و المحاضرين على إيصال رسالتهح بوضوح وتنظيمهم للمقرر واستخدام مجموعة واسعة من وسائل وتقنيات التعليم، ليست إلا مهار ات ينبغي عليهم ممارستها وتطويرها إذا ما أرادوا الانتقال من المحاضرة العادية (التقليدية) إلى استراتيجية المحاضرة المعدلة ليطبقوا تعلما نشطا محققا لنواتج تعلم أفضل وللأهداف المنشودة ولمعايير الجودة في أدائهم.

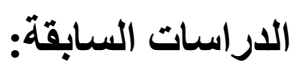
اقتصر الباحث على إيراد الدراسات وثيقة الصلة بهذه الدراسة بشكل مباشر، و التي وظفها في

$$
\text { جانب من جوانبها المهمة و هذه الدر اسات هي: }
$$

دراسة كريستيانسون وفيشر (999 (19): Chirstianason \& Fisher)، (1999 وهدفت الدر اسة إلى المقارنة بين أداء مجمو عنين إحداهن طبق عليها التعلم النشط باستخدام التعليم التعاوني (مجموعات المناقثة الصغيرة داخل المجموعة)، والأخرى اعتمدت على التدريس التقليدي، واستخدمت المنهج التجريبي، وقد توصلت إلى فعالية مجموعة التعلم النشط مقارنة بالتدريس التقليدي للمجموعة الأخرى، وذلك في الفهم الصحيح والدقيق للمفاهيم المتضمنة في موضو عات التعلم، وأوصت هذه الدراسة بإجر اء المزيد من الدراسات حول التعلم النشط في المر احل التعليمية المختلفة وفي مختلف مجالات التعلم.

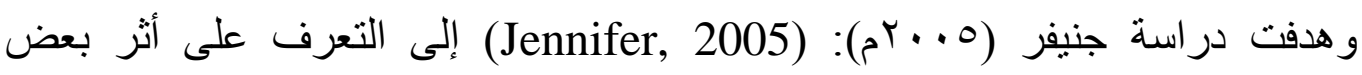

استراتيجيات التعلم النشط في التحصيل واتجاه الطلاب نحو المقررات، واستخدمت المنهج التجريبي، وتوصلت إلى أن لهذه الاستر اتيجيات تأثير إيجابي في تحصيل الطلاب في بعض المقررات ولصالح المجموعة التجريبية، كما أن اتجاه الطلاب في المجموعة التجريبية إيجابي 
ويفوق اتجاهات طلاب المجموعة الضابطة بنسبة قليلة، لكن لا يوجد فرق دال إحصائياً بينهما في الاتجاه نحو المقرر ات.

أما دراسة هول وليبيرمان (ع · . Hall\& Lieberman, 2004) فقد هدفت إلى (Ha) در اسة الأثر في التتوع باستخدام بعض استراتيجيات التعلم النشط في اكتساب بعض المفاهيم البيولوجية وتقدير الذات والاتجاه نحو إيجابية المتعلم في الموقف التعليمي، واستخدمت الدراسة عدداً من استر اتيجيات التعلم النشط تمثلت في (استراتيجية فكر، ز زاوج، شارك، وخلية التعلم، وبناء و إعداد خر ائط المفاهيم، و العصف الذهني) على من مجموعة الطلاب وقد توصلت الدراسة إلى وجود أثر كبير لتنوع استر اتيجيات التعلم النشط المستخدمة بالنسبة لاكتساب المفاهيم والاتجاه نحو الاعتماد الإيجابي المتبادل على عينة الدراسة، بينما لم تكن النتائج دالة إحصائياً بالنسبة لتحسين مستوى تقدير المتعلمين لذو اتهز. و هدفت دراسة اليتيم (9 ج · r م) إلى بحث أثر تكامل استراتيجيتين تستندان إلى فرضيات النظرية البنائية (استر اتيجية دورة التعلم، وخارطة المفاهيم) في إدر اكات الطلاب للبيئة التعليمية الصفية، ولإجابة عن السؤال: هل يختلف أثر استراتيجية التدريس التي تكامل بين استراتيجية الخارطة المفاهيمية ودورة التعلم عن أثر كل من إستراتيجيتي الخارطة المفاهيمية ودورة التعلم منفردتين في إدر اكات الطلاب للبيئة التعليمية الصفية؟، واختيرت عينة قصدية مكونة من ( • (Y) طالبا وطالبة من الصف السابع موزعين على ثلاث شعب في مدرسة للطلاب وثلاث شعب للطالبات، بحيث درست كل شعبة في كل مدرسة بإحدى الاستر اتيجيات الثلاث، وتوزعت الثعب على الاستر اتيجيات بالطريقة العشوائية البسيطة واستخدمت استبانة البيئة التعليمية البنائية و التي تكونت من (Tr) فقرة موزعة على أربعة مقاييس فرعية هي: (الملائمة الثخصية، وتفاوض الطلاب، والضبط المشترك، والصوت الناقد )، كما تم إعداد برنامج تدريسي للإستراتيجيات الثلاث، احتوى على مخططات الدروس للفصول الثلاثة في الوحدة المختارة (الخصائص المادية للمادة)، بالإضافة إلى الخر ائط المفاهيمية وأوراق العمل، وأظهرت النتائج عدم وجود فروق ذات دلالة إحصائية بين الاستر اتيجية التكاملية وإستر اتيجيتي الخرائط المفاهيمية ودورة التعلم من حيث أثرها في إدراكات الطلاب للبيئة التعلمية الصفية، كما ظهرت فروق ذات دلالة بينها في المقياس الفرعي (الملائمة الشخصية) حيث تفوقت الإستر اتيجيتان التكاملية ودورة التعلم، وأوصت الدراسة الباحثين بضرورة التوسع في مجال الاستراتيجيات التكاملية، وتطوير الطرق التوالفية التي تجمع 
بين أكثر من استراتيجية واحدة، وأكدت أن هذا المنحى يعد بنتائج إيجابية في مجال تطوير الأبحاث و الدراسات التربوية، كما أكدت على أهمية تطبيق الاستراتيجيات البنائية في التدريس بالثكل الصحيح. وكذلك هدفت در اسة الجهيمي (• ( • r م): إلى التعرف على فعالية تدريس مقرر المناهج وطرق التدريس (ترب اهب) باستخدام استراتيجية العصف الذهني في تحصيل طلاب المستوى السادس في كلية أصول الدين بجامعة الإمام محمد بن سعود الإسلامية عند المستويات المعرفية لبلوم واتجاهاتهم نحو المقرر، وطبقت المنهج شبه التجريبي، و تم تطبيق الاختبار التحصيلي (قبلي، بعدي) على المجموعتين (التجريبية و الضابطة)، وكذلك مقياس الاتجاه (قبلي، بعدي)، وتوصلت الدراسة إلى أهم النتائج أنه توجد فروق ذات دلالة إحصائية عند مستوى (0. . ) بين متوسطي درجات طلاب المجموعة التجريبية في التطبيق القبلي والبعدي للاختبار، باستخدام استراتيجية العصف الذهني في المستويات المعرفية عند بلوم لصالح درجات التطبيق البعدي ولصالح درجات المجموعة التجريبية، ولا توجد فروق ذات دلالة إحصائية عند مسنوى (0.. • بين متوسطي درجات طلاب المجموعة التجريبية في تطبيق مقياس الاتجاه القبلي والبعدي نحو المقرر، لكن توجد علاقة ارتباطية بين تحصيل الطلاب واتجاهاتهم نحو المقرر، أي كلما ارتفع التحصيل زاد اتجاه الطلاب نحو المقرر، وأوصت الدراسة بالاهتمام بالاستراتيجيات التدريسية الحديثة التي تساعد على التحصيل وتتمية قررات التفكير المختلفة، وبناء الاتجاهات الإيجابية نحو المقررات الدراسية لدى المتعلمين، واقترحت عددا من الدراسات المستقبلية التي تقارن بين الاستر اتيجيات المختلفة في تدريس المقررات.

وهدفت در اسـة العنزي (r ( • rم): إلى معرفة درجـة استخدام أعضـاء هيئة التدريس في التعليم المـوازي لاستر اتيجيات التعلم النشط، وكانت أداة الدر اسـة التي استخدمتها هـي الاستبانة و التي طبقت على عينـة مـن طلاب بعض التخصصـات في كليـة العلوم الاجتماعية بجامعة الإمـام محمد بن سعود الإسلامية وهي: (علم النفس، و علم الاجتماع و الخدمة الاجتماعية، والمناهج وطرق التدريس، والإدارة و التخطيط، و أصـول التربيـة والتربيـة الإسـلامية)، أخذت بالطريقـة العثـوائية وكان عدد أفر ادها (Y (Y))، وتوصلت الدر اسـة إلى أن أعضـاء هيئة التدريس في التعليم الموازي يمارسون إستر اتيجيات التعلم النشط بدرجات متفاوتة جاءت كلها فوق المتوسط فيما عدا استر اتيجية العصف الذهني فقد جاءت بدرجة متوسطة، وقد حصلت إستر اتيجية المحاضرة المعدلة على أعلى 


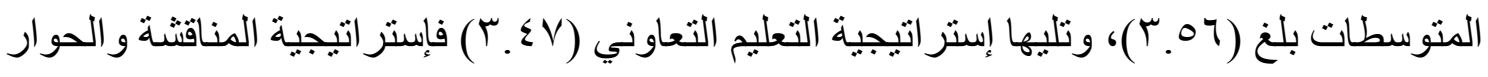

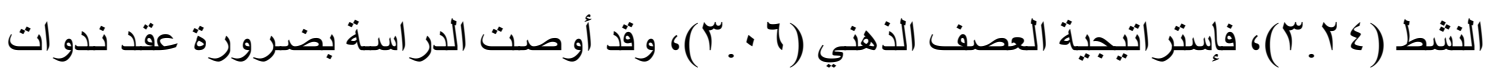
وورش عمل لأعضاء هيئة التدريس في التعليم الموازي في بعض إسئر إستر اتيجيات التعلم النشط التي تتفق مع حاجات ومنطلبات التعليم العالي وتتو افق وفلسفة التعلم النشط.

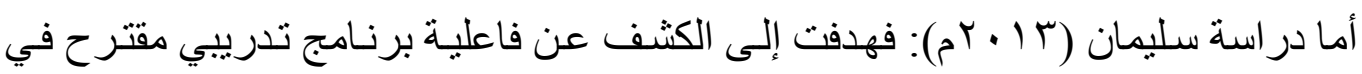

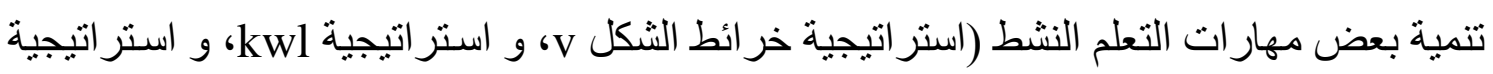

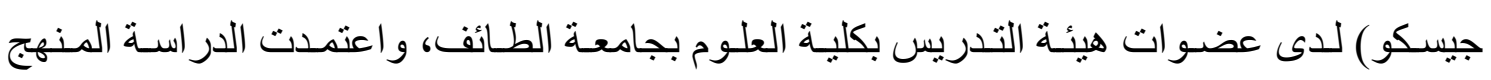

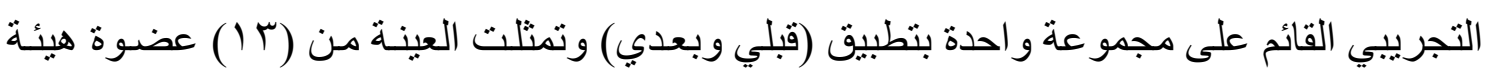
تدريس بكلية العلوم قدم لهن برنامج تدريبي حول التعلم النشط وتم قياس أدائهن القبلي و البعدي ونئي

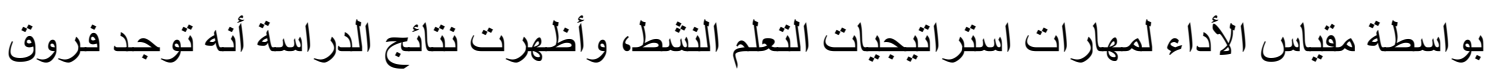
دالة إحصائيا عند مستوى (0 . . ) بين متوسطي أداء عضو ات هيئة التدريس على مقياس الأداء

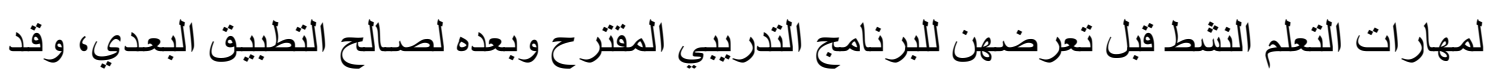

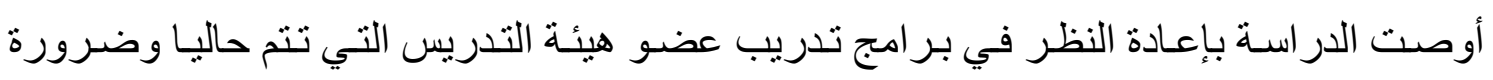

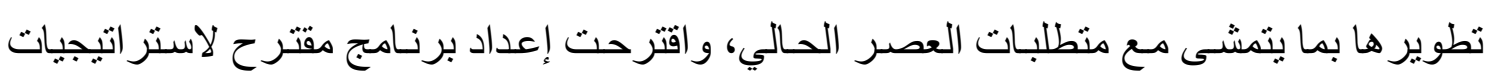

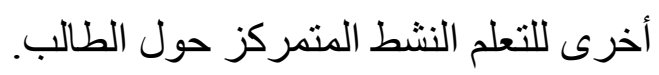
التعليق على الاراسات السابقة: من خلال استعر اض هذه الدراسات يتبين أن دراسة كريستيانسون وفيشر توصلت إلى فعالية مجموعة التعلم النشط مقارنة بالتدريس التقليدي، وذللك في الفهم الصحيح والدقيق للتئن المفاهيم المنضمنة في موضو عات التعلم، وكذلك توصلت در اسة جنيفر إلى أن استخدام استر اتيجيات التعلم

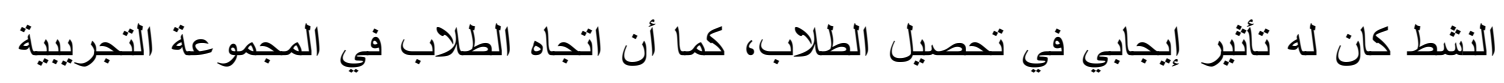

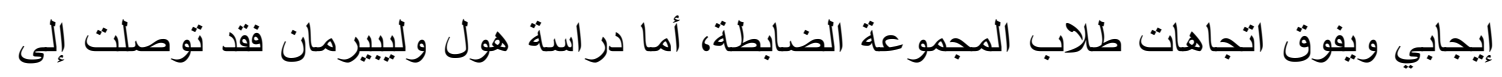

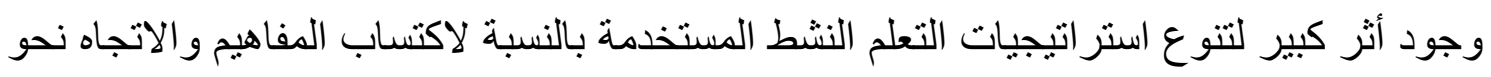

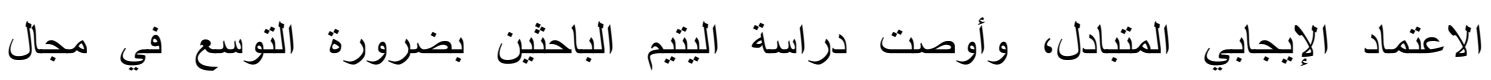
الاستراتيجيات التكاملية، وتطوير الطرق التوالفية التي تجمع بين أكثر من استراتيجية واحدة، الإنية

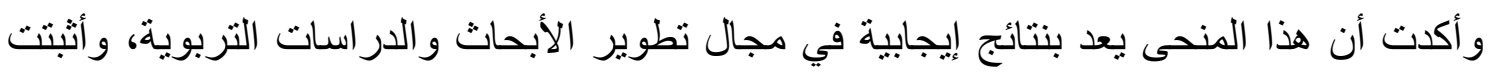

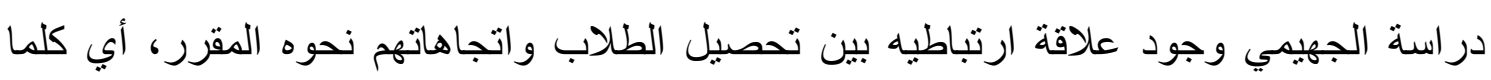


ارتفع التحصيل زاد اتجاه الطلاب نحو المقرر، وأوصت بالاهتمام بالاستراتيجيات التدريسية الحديثة التي تساعد على التحصيل وتنمية قدرات التفكير المختلفة، وبناء الاتجاهات الإيجابية نحو المقررات الدراسية لدى المتعلم، وتوصلت در اسة العنزي إلى أن أعضاء هيئة التدريس في التعليم الموازي يمارسون إستراتيجيات التعلم النشط بدرجات متفاوتة، وأوصت بضرورة عقد ندوات وورش عمل لأعضاء هيئة التدريس في التعليم الموازي في بعض إستراتيجيات التعلم النشط التي تتفق مع حاجات ومتطلبات التعليم العالي وتتو افق وفلسفة التعلم النشط، أما در اسة سليمان فقد قدمت برنامجا تدريبيا حول التعلم النشط وطبقته وتم قياس الأداء قبليا و بعديا بواسطة مقياس أداء لمهار ات استر اتيجيات التعلم النشط بني لللك، و أظهرت نتائج الدراسة وجود فرق على مقياس الأداء لمهارات التعلم النشط (قبل وبعد) في أداء عضوات هيئة التدريس اللاتي طبق عليهن البرنامج التدريبي لصالح التطبيق البعدي، وأوصت بإعادة النظر في برامج تدريب عضو هيئة التدريس التي تتم حاليا وضرورة تطوير ها بما يتمشى مع متطلبات العصر الحالي، واقترحت إعداد برنامج مقترح لاستر اتيجيات أخرى للتعلم النشط المتمركز حول الطالب، إن أهمية التنويع باستخدام استراتيجيات التعلم المختلفة، وأهمية تطبيقها وتجريبها ومقارنتها وبالذات الاستراتيجيات التي تجعل المتعلمين هم محور العملية التعليمية، ومن أبرز هذه الاستراتيجيات استراتيجيات التعلم النشط التي تسهم في رفع مستوى تحصيلهم و اكتسابهم المفاهيم والمهار ات وتتمي لديهم مهار ات التفكير العليا وتجعلهم دائمي الارتباط بما يتعلمون مما يؤثر إيجابياً على اتجاهاتهم نحو التعلم ويعزز في أنفسهم قيمته ويساهم في تطوير مهار اتهم الاجتماعية ويجعلهم أكثر إنتاجية و إدر اكا لأدوارهم في بناء مجتمعاتهم ورفعة شأن أمتهم، حيث أكدت نتائج هذه الدراسات على أن التعلم وفق هذه الاستراتيجيات له أثر في دعم التعلم وزرع الثقة في نفوس المتعلمين حيث يتلقون من خلالها الكثير من التشجيع والدعم عندما يسلمون مسئولية قيادة عمليات التعلم بأنفسهم وتتاح الفرصة لهم لإبداء آرائهم و العمل بأنفسه، و هذا ما تؤكده هذه الدراسات و غيرها في مجالها وأدبيات التعلم النشط من أن التعلم يحدث بشكل ناجح في تحقيق نواتج التعلم عندما يشثرك المتعلمون في توليد المعرفة وتحمل مسؤوليات موجهة ومحددة ومحببة أثناء عمليات التعلم أكثر من استقبالها استقبالا جزئيا أو سلبيا أحيانا بحيث يكون دور المعلم الفاعل ميسراً للتعلم أكثر من أن يكون المصدر الأساس للمعرفة. أما من حيث أوجه الثبه و الاختلاف بين تللك الدر اسات و الدر اسة الحالية فتلخص بالتالي: 
ا ــ اتفقت الدراسات السابقة مع هذه الدر اسـة في استخدام المنهج شبه التجريبي منهجاً للار اسـة وبناء على المنهج المتبع فقد اتفقت أيضا مع هذه الدراسـة في استخدام الاختبار أداة للار اسـة

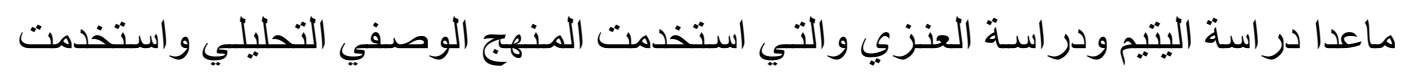
الاستبانة أداة للار اسة. r ـ اتفقت الدر اسـات السـابقة مـع هذه الدر اسـة على أهميـة إستر اتيجيات التعلم النشط و المقارنـة

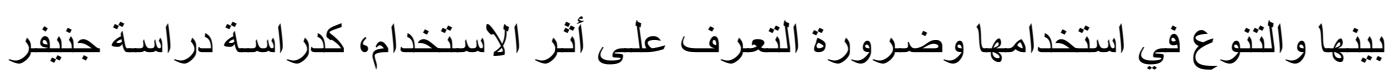

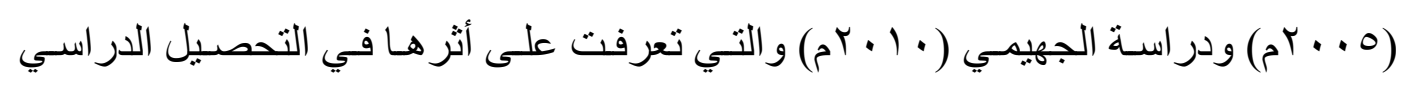

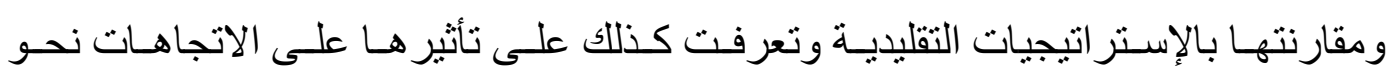

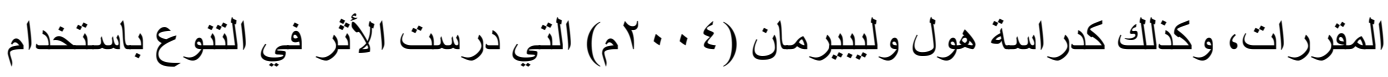

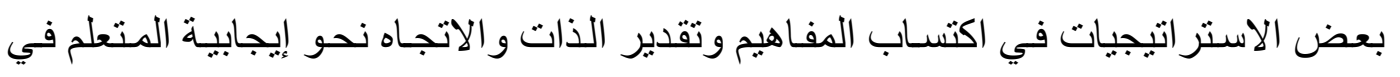

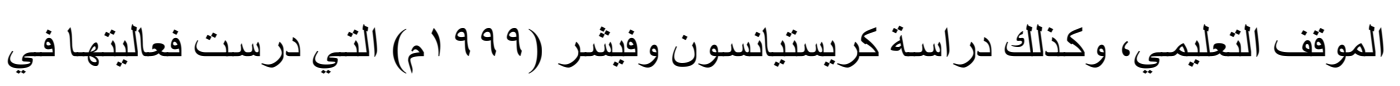

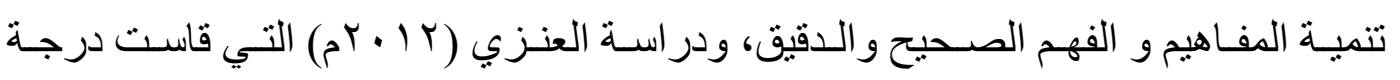
استخدام بعض هذه الإستر اتيجيات في تدريس عدد من المواد الدراسية، ودر اسـة سليمان

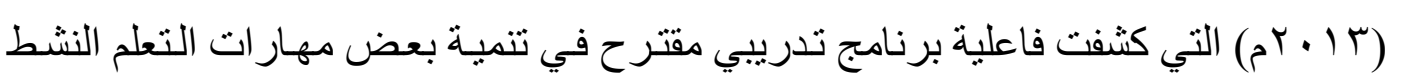

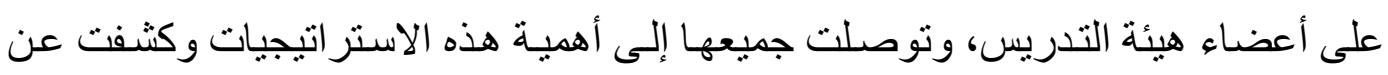
دور ها في دعم التعلم وتعزيزه.

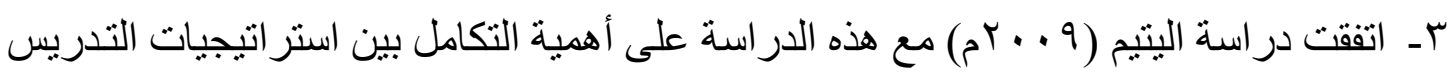

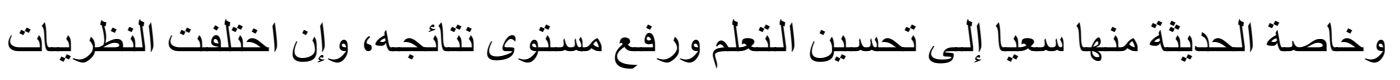
التي تبنى على أسسها هذه الاستر اتيجيات حيث الهدف هو تحقيق أهداف التعلم وتحسين

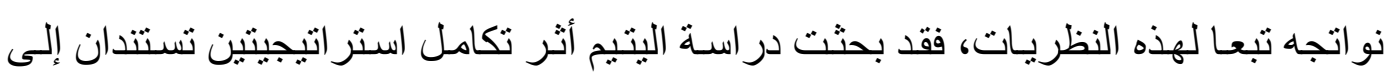

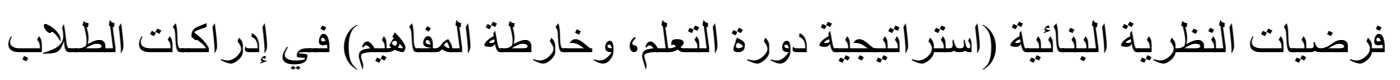
للبيئة التعليمية الصفية، وبحثت هذه الدر اسة في أثر التكامل بين إستر اتيجيتي التعلم النشط:

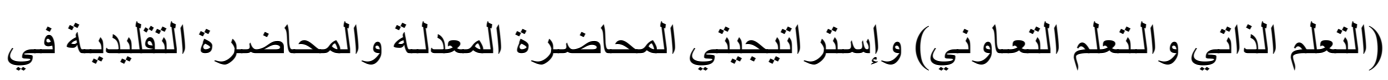

$$
\text { تنمية التحصيل الدراسي. }
$$

ع ـ اختلفت هذه الدر اسة عن الدراسات السابقة في معرفة أثر التكامل بين إستر اتيجيتي التعلم

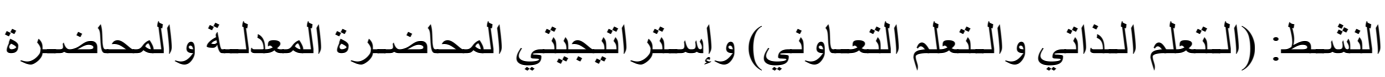


التقليدية في تتمية التحصيل الدر اسي، وهذا يفردها عن غير ها حيث تعرفت على أثر التكامل بين إستر اتيجيتين حديثتين تعدان من أبرز الاستر اتيجيات الحديثة في مستويات التحصيل المختلفة وقارنت ذلك أيضا بإستر اتيجية المحاضرة المعدلة و التي تعد من إستر اتيجيات التعلم النشط و المقارنة بينها وبين استر اتيجية المحاضرة التقليدية للتعرف على أنه ليس كل جديد حسن على الإطلاق و لا كل قديم سيئ كذللك، وكذلك اختلف مجتمع الدر اسـة حيث اعتـاد هذا المجتمع على استخدام استر اتيجية المحاضرة التقليدية غالبا وبشكل كبير جدا نظر لاعتبار ات كثيرة من أهمها أن استخدام الجديد يحتاج إلى وقت للتخطيط و الإعداد بعكس مـا اعتاد عليه الإنسان و عدم التعرف و التدرب على الإستر اتيجيات الحديثة من قبل الأسـاتذة و عدم وجود حفز لذلك، بالإضافة إلى كثرة الطلاب في قاعات الدرس ومقاومتهم لها حتى لا يفارقو ا مـا اعتادوا عليه وحتى لا تزداد تكاليفهم. هـ ـ وقد أفاد الباحث من جميع هذه الدر اسـات في تكوين نظرة عامـة وصو لاً إلى بنـاء تصـور

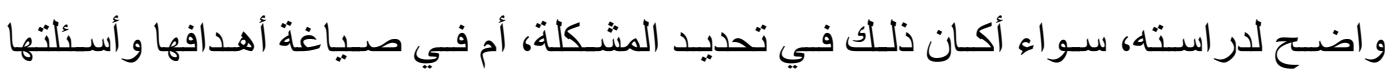
وفروضها، أم في منهجها و وجتمعها و عينتها وأداتها، أم في استخدام المقارنـات و المعالجات الإحصائية ناهيك عن إطار ها المفاهيمي ونظرياتها ودر اساتها السـابقة، والتي وظفها جميعا

$$
\text { إجي در استه. }
$$

منهج الاراسـة: اعتمدت هذه الدراسـة على المنهـج شبه التجريبي، وهـو المنهج "الذي "يستطيع الباحث بو اسطته أن يعرف أثر السبب (المتغير المستقل) في النتيجة (المتغير التابع) "r.

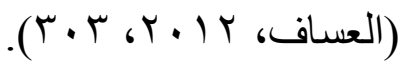
ومن أجل الإجابة عن أسئلة الدر اسة و التحقق من صحة فروضـها، استخدم الباحث التصميم التجريبي القائم على "استخدام ثلاث مجموعات متكافئة: اثنتين تجريبيتين، و هما المجموعـة الأولى التي تتعـرض للمتغير التجريبـي (المتغير المستقل الأول) لمعرفـة تأثير هذا المتغير فيهـا وهـو: (التكامل بين إستر اتيجيتي التعلم التعاوني و التعلم الذاتي)، والمجمو عة الثانية التي تتعرض للمتغير التجريبـي الثـاني (المتغيـر المسـتقل الثـاني) لمعرفـة تـأثير هـذا المتغيـر فيهـا وهـو: (إسـتر اتيجية المحاضـرة المعدلـة)، و المجمو عـة الثالثـة الضـابطة، وهـي المجمو عـة التي لا تتعـرض للمتغير ات 
التجريبيـة، وتبقى تحـت الظـروف العاديـة و التـي اسـتخدمت فيهـا إسـتر اتيجية المحاضـرة العاديـة

مجتمع الدراسة وعينتها: يتكون مجتمع الدراسة من طلاب المستوى السادس في كلية الشريعة بجامعة الإمام محمد بن سعود الإسلامية، حيث بلغت عينة الدر اسة (ه ب ( ) طالباً، موزعين على ثلاث مجمو عات: الأولى و الثانية تجريبيتين و الثالثة ضابطة، وقد بلغ عدد المجمو عة التجريبية الأولى (7٪) طالباً، وبلغ عدد المجموعة التجريبية الثانية (0ء) طالبا، وبلغ عدد المجموعة الضابطة الثالثة (عـ) طالبا، وهم من اكتملت بياناتهم وتحققت فيهم شروط التجربة ولم يحصل منهم تسرب خلال فترات التنفيذ، ودرسوا جميعا مكونات المنهج المدرسي (الأهداف، المحتوى، الأنشطة التعليمية، التقويم) باستخدام الإستراتيجيات الثلاث، وقد تم اختيار العينة بالأسلوب القصدي، حيث تم إسناد التدريس إلى الباحث في الفصل الثاني من العام الجامعي سبء عـ

متغيرات الدراسة: المتغير ات المستقلة: التي استخدمت في هذه الدراسـة (المتغير المستقل الأول) (التكامـل بـين إسـتر اتيجيتي التعلم التعـاوني و التتعلم الذاتي) والذي طبـق على المجموعـة التجريبية الأولى، (و المتغير المستقل الثاني) (إستر اتيجية المحاضـرة المعدلة) و الذي طبق على الهى المجمو عة التجريبية الثانية، مقارنة بإستر اتيجية المحاضرة العادية (التقليديـة السـائدة) و التي طبقت على المجمو عة الضابطة. المتغير التـابع: ويتمثنل المتغير التابع في معرفـة مستوى تحصيل الطـلاب المعرفي في المستويات المعرفيـة عند بلـوم (التذكر، الفهم، التطبيـق، التحليـل، التركيب، التقويم)، لدى عينـة الدراسة

أداة الدراسة: من أجل تحقيق أهدف الدراسـة، ستكون الأداة الرئيسـة المستخدمة فيها هي (اختبار تحصيلي موضو عي من نوع اختيار من متعدد؛ إذ أنها كما يذكر (غانم، 1 (أ (اهـ، هب ا)): " من أكثر الاختبار ات الموضو عية انتشار اً، و أكثرها صدقاً وثباتاً "، وقد استخدم الباحث الاختبـار التحصيلي الذي قام الجهيمي ( • • (rم) ببنائه و تحكيمه وتحقق من صدقه وثباته، وذللك لكون مقرر المنـاهج وطرق التدريس الذي يدرس في كليـة أصـول الدين، وفي كليـة الثـريعة مقررا موحدا (متطلب) وفق الخطة التدريسية والتوصيف و المفردات المعتمدة في الجامعة، وقد بني هذا الاختبار وفق مواصفات الاختبار الجيد، وكانت نسبة الاتفاق عليه من قبل المحكمين عالية، حيث تم حساب 
معامل ثباته باستخدام معامل ثبـات كودر ريتشاردسون _ _ ب، ومعامل جتمـان للتجزئة النصفية، ومسن ثم تطبيق معادلة تصـحيح الطول لسبير مان بر اون، فكانت نسبة ثبـات كودر رنتشاردسون

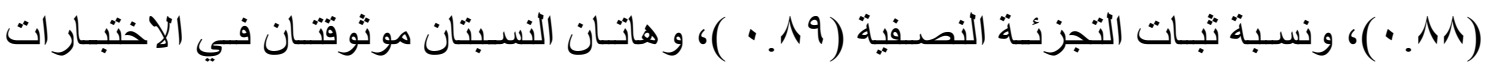
التحصيلية، وقد تأكد الباحث مـن أن الاختبـار يحقق أهداف الدر اسـة ويجيب عن أسـئلتها وذلك بمر اجعته و عرضه على عدد من المختصبن، ويتكون من (؟Y) سؤالاً موز عـة حسب المستويات المعرفية الستة: (التذكر، الفهم، التطبيق، التحليل، التركيب، التقويم) كمـا يوضـح ذلك الجدول (Y)، ويوضح الجدول (r) توزيع أسئلة الاختبار على المستويات المعرفية الستة:

$$
\text { جدول (r) }
$$

يبين مواصفات اختبار التحصيل وفق المحتوى (مكونات المنهج) و عدد الأسئلة لكل مستوى

\begin{tabular}{|c|c|c|c|c|c|c|c|}
\hline \multicolumn{7}{|c|}{ المستويات المعرفية } & \multirow{2}{*}{ مكونات المنهج } \\
\hline المجموع & التقويم & التركيب & التحليل & التطبيق & الفهم & التذكر & \\
\hline 9 & $\cdot$ & $r$ & - & - & $r$ & 1 & الأهداف \\
\hline 0 & r & - & - & 1 & 1 & 1 & المحتوى \\
\hline 9 & r & 1 & $\varepsilon$ & 1 & . & 1 & الأنثطة التعليمية \\
\hline$\varepsilon$ & 1 & . & ". & 1 & 1 & 1 & التقويم \\
\hline$r \varepsilon$ & 0 & $r$ & $\varepsilon$ & $r$ & 0 & $\varepsilon$ & المجموع \\
\hline
\end{tabular}

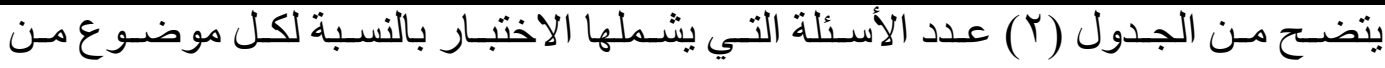
موضو عات المحتوى، و علاقته بكل مستوى من المستويات المعرفية الستة، وتحديد عدد أسئلة كل مكون من مكونات المنهج الأربعة من مقرر المناهج وطرق التدريس في المستوى السادس في كليـة

$$
\text { الثريعة ترب (10) - (ب). }
$$

\begin{tabular}{|c|c|c|}
\hline المجموع & أرقام الأسئلة في الاختبار التحصيلي & المستوى \\
\hline$\varepsilon$ & $r r, r \cdot 606 r$ & التذكر \\
\hline 0 & Y1.1061Y,Y61 & الفهم \\
\hline 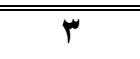 & 1961867 & التطبيق \\
\hline$\varepsilon$ & $1 \Lambda_{6} 1 V_{6} V_{6}$ & التحليل \\
\hline 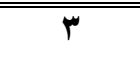 & 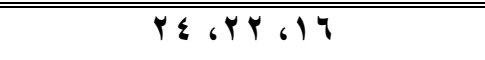 & التركيب \\
\hline 0 & $1 \leq 61161.6961$ & التقويم \\
\hline$r \varepsilon$ & & المجموع \\
\hline
\end{tabular}

جدول (T) يبين توزيع أسئلة الاختبار التحصيلي على المستويات المعرفية الستة 


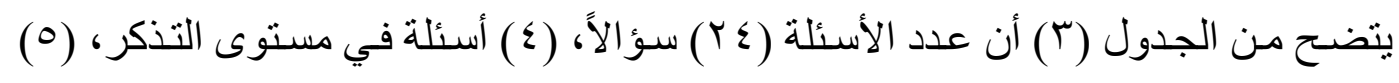

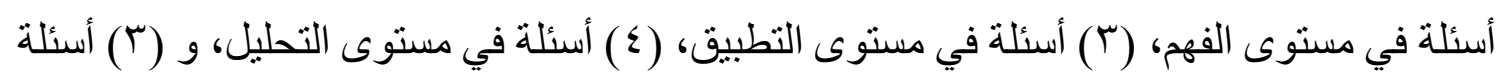
في مستوى التركيب، و (0) أسئلة في مستوى التقويم. صدق أداة الدراسة وثباتها: تم التأكد مـن ثبـات الأداة باستخدام ثبـات ألفـا كرونبـاخ لأبعـاد الأداة و الدرجـة الكليـة لـلأداة، وقد أظهرت معاملات ألفا كرونباخ درجة عالية من الثبات.

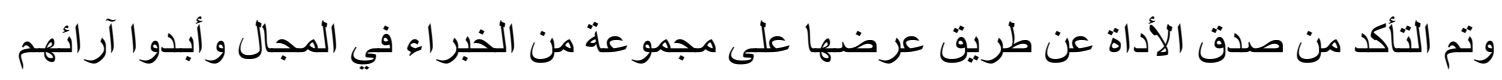
حول مدى قياسها لما وضعت لأجله وتم الأخذ بما أبدوه من ملاحظات. إجر اءات التطبيق: تمت إجراءات تطبيق الدراسة وفق الخطوات التهات التالية:

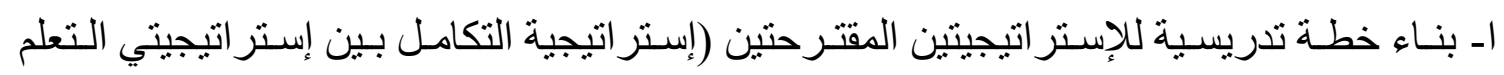

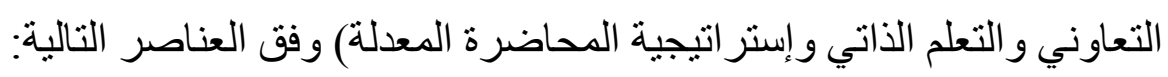
ا - التحديد أهداف الخطة. r- تحديد الأساليب وطر ائق التدريس و الأنشطة (الفردية) و والجماعية) أثناء بنـاء الخطة ورسم استر اتيجيتي هذه الدراسة.

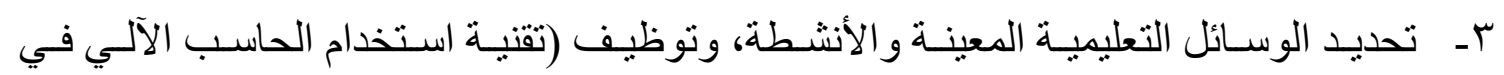
التدريس) أنثاء بناء الخطة ورسم استر اتيجيتي هذه الدر اسة. ع - تحديد عمليات التقويم في الاستر اتيجيتين و شموليتها لكل الأهداف التي تم بناؤهاء هاوتحكيمها في لئي

$$
\text { إطار حدود الدراسة لهذه الدراسة. }
$$

هـ تحديد الخطة التدريسية المتكاملة (الدليل الإجر ائي) لإعداد محاضر ات الإستر اتيجيتين، والتي تثنل الموضو عات (مكونات المنهج المدرسي بمفهومه الحديث: الأهداف، المحتوى، الأنشطة التعليمية، التقويم). 7- تطبيق الدراسة التجريبية على عينة الدراسة، حيث تم خلال ذلك ما يلي:

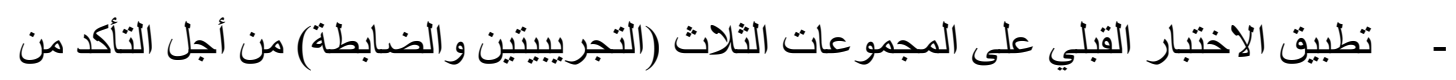
تحقيق التكافؤ بين المجمو عات قبل بدء التجربة.

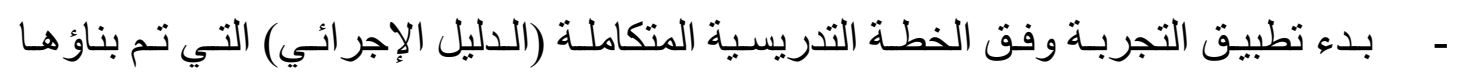
وتحكيمها. 
تطبيـق الاختبـار التحصـيلي البعدي بعد الانتهاء مباشـرة من التدريس على المجموعـات

$$
\text { الثلاث (التجريبيتين و الضابطة). }
$$

- استخلاص النتائج، وتحليلها، وربطها بالدر اسـات السـابقة، وتفسير ها، وكتابـة التوصيات

$$
\text { تكافؤ مجمو عات الدر اسةة: }
$$

قام الباحث بتطبيق الاختبار التحصيلي القبلي على الثعب الثناث (مجموعات الدراسة): (التجريبيتين والضابطة) قبل البدء بتطبيق التجربة، وتم تحليل التباين للمستويات المعرفية الدنيا وكذلك للمستويات المعرفية العليا باستخدام اختبار شفية، بهدف التحقق من تكافؤ المجموعات قبل

بدء التجربة:

ا ـ اختبار تحليل التباين بين المجمو عات الثلاث قبل بدء التجربة في المستويات المعرفية الدنبا

$$
\text { (التذكر، الفهم، التطبيق) وكانت النتيجة كما يوضح الجدول (ع) و الجدول (0): }
$$

\begin{tabular}{|c|c|c|c|}
\hline الانحراف المعياري & المتوسط الحسابي & عددها & اسم المجموعة \\
\hline $1 . r \wedge \wedge$ & o.rv. & $\leqslant 7$ & المجموعة التجريبية الأولى \\
\hline $1.1 \mathrm{VV}$ & $0.0 \vee \wedge$ & $\leqslant 0$ & المجموعة التجريبية الثانية \\
\hline $1.0 \leq 0$ & 0.091 & $\varepsilon \varepsilon$ & المجموعة الضابطة \\
\hline
\end{tabular}

جدول ( ) يبين المتوسط الحسابي و الانحر اف المعياري لدرجات الطلاب في المجمو عات الثلاث

\begin{tabular}{|c|c|c|c|c|c|c|}
\hline التعليق & مستوى الدلالة & قيمة ف & مجموع المربعات & المربعات & الحرية & مصدر التباين \\
\hline \multirow{3}{*}{ غير دالة } & \multirow{3}{*}{.794} & \multirow{3}{*}{$\cdot r v$. } &.$v \cdot 1$ & $1 . \varepsilon \cdot r$ & $r$ & بين المجموعات \\
\hline & & & 1.199 & ro. rrr & Irr & الباقي \\
\hline & & & & rol.VTr & $1 T \leq$ & المجموع الكلي \\
\hline
\end{tabular}
في المستويات الدنيا قبل التجربة

جدول (0) يبين نتائج تحليل التباين بين المجمو عات الثناث قبل بدء التجربة في المستويات الدنيا

$$
\text { مستوى الدلالة: (0. • ) }
$$


يتضح من الجدول (0) أن الفروق بين المتوسطات ليست دالة حصائيا عند مستوى (0 . . ) مما يؤكد تكافؤ المجمو عات الثلاث في المستويات المعرفية الدنيا( التذكر، الفهم، التطبيق) قبل البدء بالتجربة. ץ ـ اختبار تحليل التباين بين المجمو عات الثلاث قبل بدء التجربة في المستويات العليا (التحليل، (التركيب، التقويم)، وكانت النتيجة كما يوضح الجدول (ج)، و الجدول (V) جدول (†) يبين المتوسط الحسابي والانحر اف المعياري لدرجات الطلاب في الاختبار القبلي للمجمو عات الثناث في المستويات العليا

\begin{tabular}{|c|c|c|c|}
\hline الانحراف المعياري & المتوسط الحسابي & عددها & اسم المجموعة \\
\hline 1.10 & 0.7 .9 & $\leqslant 7$ & المجموعة التجريبية الأولى \\
\hline $1.1 \mathrm{Vr}$ & $0 . \wedge r r$ & $\leqslant 0$ & المجموعة التجريبية الثانية \\
\hline 1.211 & 0.709 & $\leqslant \varepsilon$ & المجموعة الضابطة \\
\hline
\end{tabular}

جدول (V)يبين نتائج تطبيق اختبار تحليل التباين بين المجموعات الثلاث قبل بدء التجربة في المستويات العليا

\begin{tabular}{|c|c|c|c|c|c|c|}
\hline التعليق & مستوى الدلالة & قيمة ف & مجتوسط & المربعات & الحرجة & مصدر التباين \\
\hline \multirow{3}{*}{ غير دالة } & \multirow{3}{*}{ 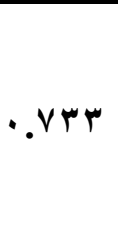 } & \multirow{3}{*}{$\cdot .411$} & $.07 \varepsilon$ & $1.1 \mathrm{rV}$ & $r$ & بين المجموعات \\
\hline & & & $1.11 \varepsilon$ & rqq.\&Y & Irr & الباقي \\
\hline & & & & $r \leqslant \cdot .0 \leqslant 1$ & $1 \mu \varepsilon$ & المجموع الكلي \\
\hline
\end{tabular}


يتضح من الجدول (V) أن الفروق بين المتوسطات ليست دالة حصائيا عند مستوى (0.. ) )،

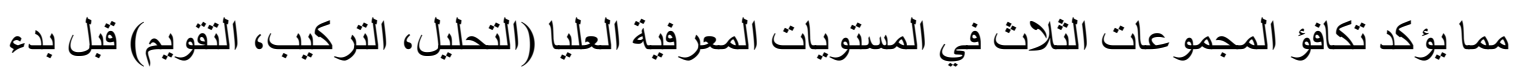
التجربة.

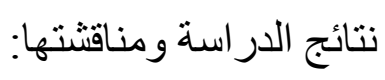

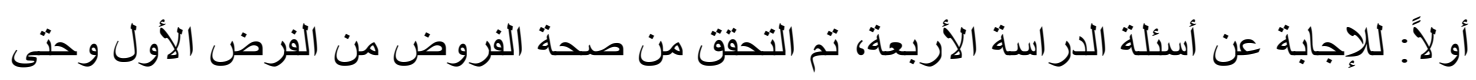

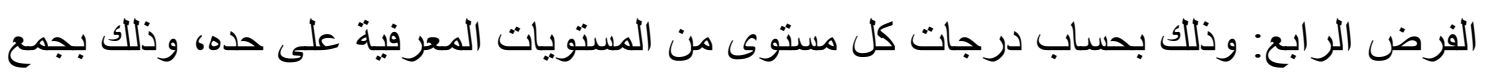

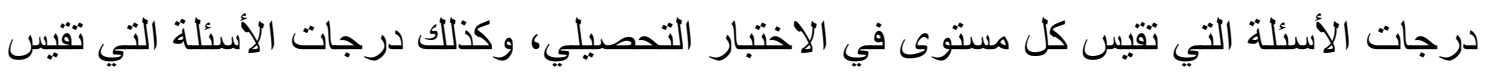

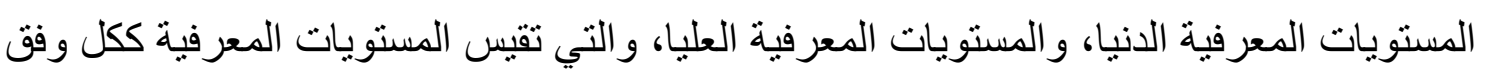

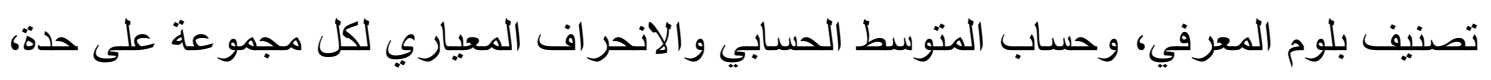

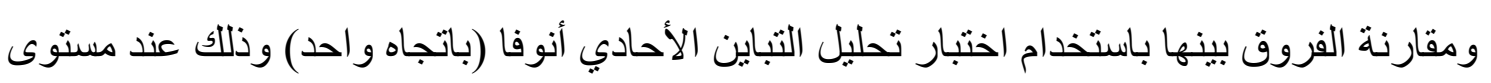

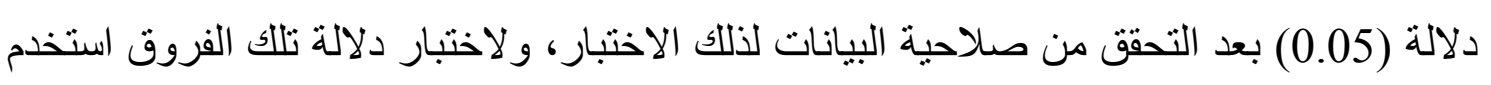
الباحث اختبار توكي للمقارنات المتعددة بين منوسط درجات الطلاب في المجموعات الثناث،

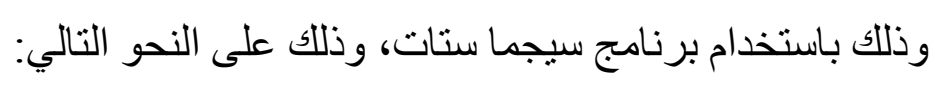

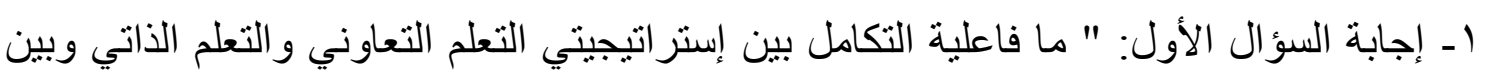
استخدام إستراتيجية المحاضرة المعللة مقارنة باستخدام إستر اتيجية المحاضرة العادية (التقليدية)

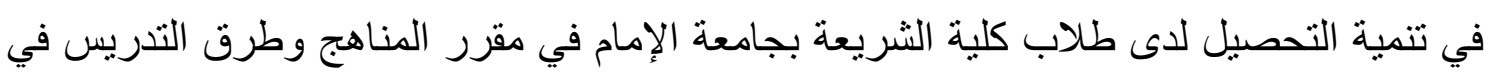

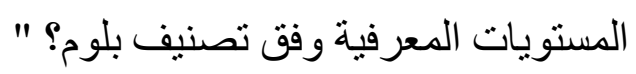
للإجابة عن السؤال الأول تم اختبار صحة الفرض الأول للار اسة، و الذي نص على (لا توجد

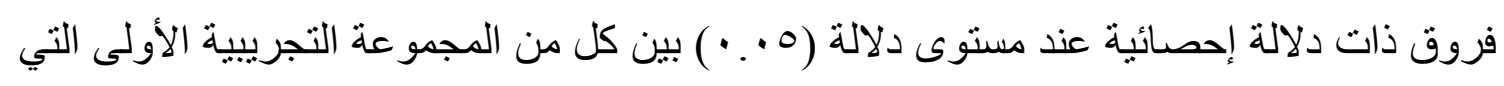

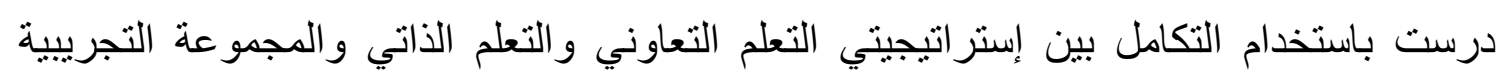

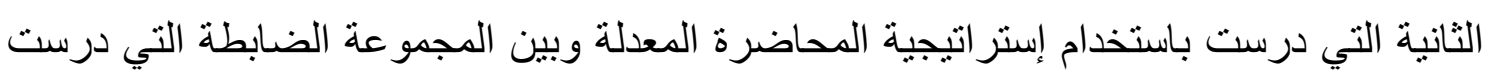
باستخدام إستراتيجية المحاضرة العادية في درجات المستويات المعرفية (التذكر - الفهم ـ التركيب ـ التحليل ـ التطبيق ـ التقويم) من الاختبار التحصيلي لدى طلاب كلية الثريعة بجامعة الإمام في

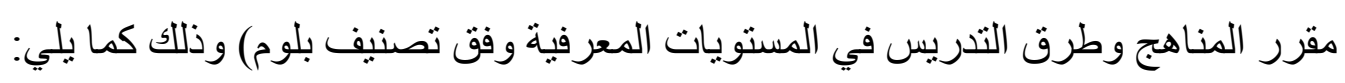

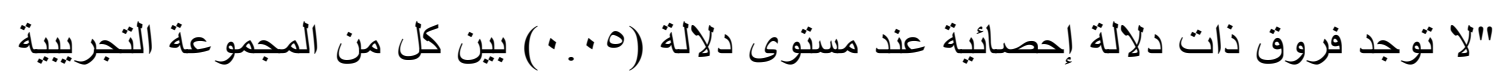

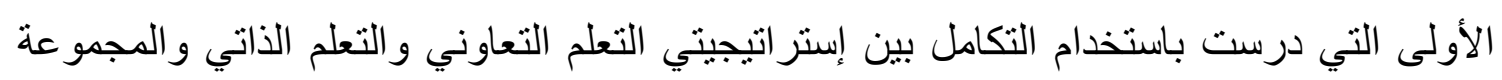


التجريبية الثانية التي درست باستخدام إستر اتيجية المحاضرة المعدلة وبين المجموعة الضابطة التي درست باستخدام إستراتيجية المحاضرة العادية في درجات مستوى التذكر من الاختبار التحصيلي لدى طلاب كلية الثريعة بجامعة الإمام في مقرر المناهج وطرق التدريس "، قام الباحث بحساب المتوسط الحسابي والانحر اف المعياري لكل مجمو عة ومقارنة الفروق بينها باستخدام اختبار تحليل التباين الأحادي أنوفا بعد التحقق من صلاحية البيانات لذلك الاختبار، وتبين أن الفروق بين المتوسطات ذات دلالة إحصائية عند مستوى أكبر من (0 . • ) كما يتضح ذلك في الجدول (^)، و الجدول (9)، ولتحديد موضع هذه الفروق تم استخدام اختبار توكي للمقارنات المتعددة بين منوسط درجات الطلاب في المجموعات الثلاث في مستوى التذكر ، كما يوضح ذللك الجدول (• (): جدول (^)يبين المتوسط الحسابي و الانحر اف المعياري لكل من المجمو عات الثناث في مستوى التذكر

\begin{tabular}{|c|c|c|c|}
\hline الانحر اف المعياري & المتوسط الحسابي & العدد & اسم المجموعة \\
\hline 1.971 & 1.907 & $\leqslant 0$ & المجموعة التجريبية الثانية \\
\hline.$\wedge 00$ & r.YqI & $\varepsilon 7$ & المجموعة التجريبية الأولى \\
\hline$\cdot \wedge 90$ & $1.71 \leq$ & $\leqslant \leqslant$ & المجموعة الضابطة \\
\hline
\end{tabular}

يتضح من الجدول (^) وجود فروق بين المتوسطات الحسابية للمجمو عات الثناث في مستوى التذكر من الاختبار التحصيلي، و لاختبار دلالة تلك الفروق استخدم الباحث اختبار تحليل التباين باتجاه و احد، كما يوضح ذلك الجدول (9): جدول (9)يبين دلالة الفروق بين متوسط درجات الطلاب في المجمو عات الثناث في مستوى التذكر

\begin{tabular}{|c|c|c|c|c|c|}
\hline الاحتمال & قيمة ف & متوسطات المربعات & مجموع المربعات & لدرجة & مصدر التباين \\
\hline$\because \cdot 1 r$ & $\varepsilon . O T r$ & $\varepsilon . V \backslash Y$ & Q. $\leqslant$ Y० & $r$ & بين المجموعات \\
\hline & & 1.49 & ITV.YIY & ITr & داخل المجموعات \\
\hline & & & $1 \leq 7.7 \mathrm{rV}$ & $1 T \varepsilon$ & المجموع \\
\hline
\end{tabular}
مستوى الدلالة أكبر من (0. • ( ) يتضح من الجدول (9) أن الفروق بين المتوسطات ذات دلالة إحصائية عند مستوى أكبر من (0. . • ) ولتحديد موضع تللك الفروق استخدم الباحث اختبار توكي للمقارنات المتعددة بين منوسط درجات الطلاب في المجموعات الثلاث في مستوى التذكر، كما يوضح ذلك الجدول ( • (): 
جدول (• ( ) يبين نتائج اختبار توكي للمقارنات المتعددة بين متوسط درجات الطلاب في

المجمو عات الثلاث في مستوى التذكر

\begin{tabular}{|c|c|c|c|c|c|}
\hline الدلالة & الاحتمال & $\mathbf{Q}$ & $\mathbf{P}$ & الفرق بين المتوسطين & المقارنة \\
\hline دالة & $\because v V$ & \&.YOV & $r$ & $\because .7 \leqslant V$ & المجموعة التجريبية الأولى - الضبطة \\
\hline غير دالة & . rYt & $r . \cdot r$. & $r$ &.$\mu \cdot \theta$ & المجموعة التجريبية الثانية التجية \\
\hline غير دالة & $\because$ YOr & Y.YMV & $r$ & $. r \leq r$ & المجموعة التجريبية الثانية ـ الضموعة الضيطة \\
\hline
\end{tabular}

يتضح من الجدول ( • () وجود فروق بين المجموعة التجريبية التي درست باستخدام التكامل بين إستر اتيجيتي التعلم التعاوني و التعلم الذاتي و المجمو عة الضابطة التي درست باستخدام إستر اتيجية المحاضرة العادية لصالح المجموعة التجريبية؛ ويُرجع الباحث ذلك إلى أن ما تم من تفاعل وبحث ونقاش باستخدام التكامل بين التعلم التعاوني والتعلم الذاتي قد ساعد على تذكر المعلومات وسهولة استرجاعها بشكل أفضل من المجموعة التي درست باستخدام إستر اتيجية المحاضرة العادية، بينما لم يظهر فرق بين المجموعة التجريبية الأولى والمجموعة التجريبية الثانية مما يعني تكافؤ المجموعتين التجريبيتين من حيث الأثر في مستوى التذكر؛ وهذا مؤشر على أن الاستراتيجيتين المستخدمتين في التجربتين كلتيهما ينميان وبشكل متساوي مستوى التذكر بشكل بيساعد على المعرفة والحفظ، كما يُظهر الجدول أنه لا يوجد فرق بين المجموعة التجريبية الثانية التي درست باستخدام إستراتيجية المحاضرة المعدلة والمجموعة الضابطة التي درست باستخدام إستر اتيجية المحاضرة العادية ؛وهذا بعني أن فرص الاسترجاع والحفظ في مستوى التذكر قد تكافأتا عند استخدام الإستر اتيجيتين: (المحاضرة المعدلة و المحاضرة العادية )، و من ذلك فإنه: - ل لا توجد فروق ذا دلالة إحصائية عند مستوى دلالة (0.05) بين كل من المجموعة التجريبية الأولى التي درست باستخدام التكامل بين إستراتيجيتي التعلم التعاوني والتعلم الذاتي و المجمو عة التجريبية الثانية التي درست باستخدام إستراتيجية المحاضرة المعدلة، وكذلك بين المجموعة التجريبية الثانية التي درست باستخدام إستر اتيجية المحاضرة المعدلة و المجموعة الضابطة التي درست باستخدام إستراتيجية المحاضرة العادية وذللك في درجات مستوى التذكر من الاختبار التحصيلي لاى طلاب كلية الثريعة بجامعة الإمام في مقرر المناهج وطرق التدريس. 
- توجد فروق ذات دلالة إحصائية عند مستوى دلالة (0.05) بين كل من المجموعة التجريية الأولى التي درست باستخدام التكامل بين إستراتيجيتي التعلم التعاوني والتعلم

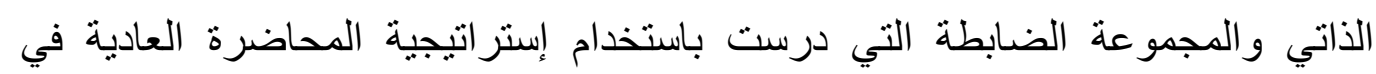

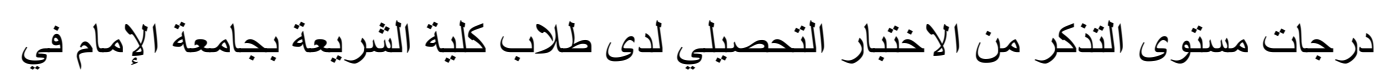
مقرر المناهج وطرق التدريس لصالح المجموعة التجريبية الأولى.

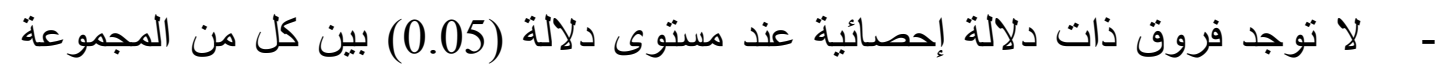

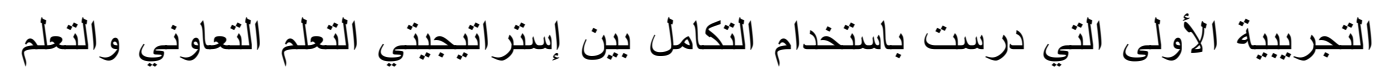

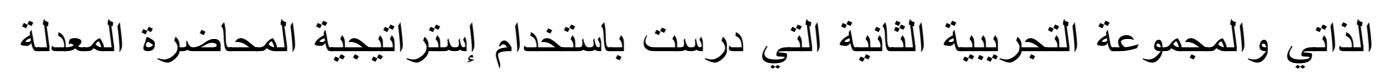
وبين المجموعة الضابطة التي درست باستخدام إستراتيجية المحاضرة العادية في درجات مستوى الفهم من الاختبار التحصيلي لاى طلاب كلية الثريعة بجامعة الإمام في مقرر

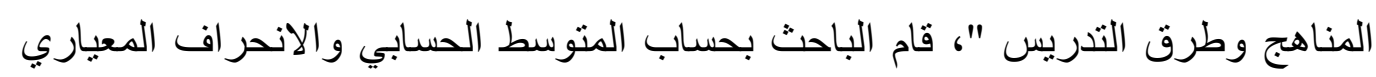

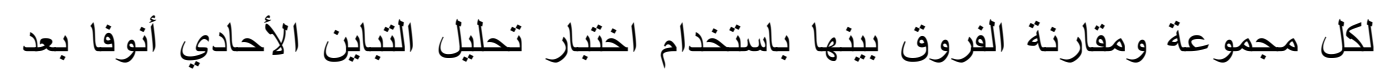

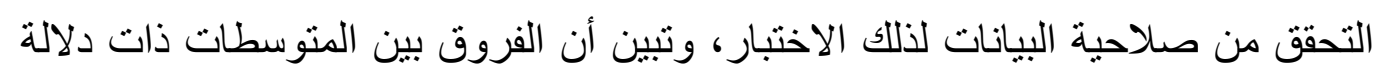
إحصائية عند مستوى (0.05) كما يتضح ذلك في الجدول (11)، و الجدول (12)، ولتحديد موضع هذه الفروق نم استخدام اختبار توكي للمقارنات المتعددة بين متوسط درجات الطلاب في المجمو عات الثلاث في مستوى الفهم كما يوضح ذلك الجدول (13):

$$
\text { جدول (1) (1) }
$$

يبين المتوسط الحسابي و الانحر اف المعياري لكل من المجموعات الثناث في مستوى الفهم

\begin{tabular}{|c|c|c|c|}
\hline الانحراف المعياري & المتوسط الحسابي & العدد & اسم المجموعة \\
\hline$\cdot \wedge 7$. & T.rVA & $\leqslant 0$ & المجموعة التجرييية الثانية \\
\hline $1 . T \leq$ & r.AV. & $\leqslant 7$ & المجمو عة التجريبية الأولى \\
\hline 1.1. & $Y . \Gamma \xi 1$ & $\varepsilon \varepsilon$ & المجمو عة الضابطة \\
\hline
\end{tabular}

يتضح من الجدول (1 (1) وجود فروق بين المتوسطات الحسابية للمجموعات الثلاث في مستوى الفهم من الاختبار التحصيلي، ولاختبار دلالة تلك الفروق استخدم الباحث اختبار تحليل التباين

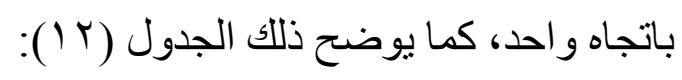


جدول (Y ( ) يبين دلالة الفروق بين متوسط درجات الطلاب في المجمو عات الثناث في مستوى الفهم

\begin{tabular}{|c|c|c|c|c|c|}
\hline الاحتمال & قيمة ف & متوسطات المربعات & المربعوع & الدرجة & مصدر التباين \\
\hline$<\cdot \cdots l$ & $r q . \cdot 1 q$ & YV.YOT & $0 \varepsilon .011$ & r & بين المجموعات \\
\hline & & $\because 9 \mu V$ & Irr.YAr & ITr & داخل المجموعات \\
\hline & & & $1 \vee \wedge .19 \%$ & IT & المجموع \\
\hline
\end{tabular}

يتضح من جدول (Y I) وجود فروق بين متوسطات المجموعات الثلاث هذه الفروق ذات دلالة إحصائية عند مستوى (0. . •)، حيث تم اختبار دلالة تلك الفروق باستخدام اختبار تحليل التباين باتجاه واحد، ولتحديد موضع تلك الفروق استخدم الباحث اختبار توكي للمقارنات المتعددة بين المجمو عات الثناث في مستوى الفهم، كما يوضح ذلك الجدول (r ا ): جدول (T ا ) يبين نتائج اختبار توكي للمقارنات المتعددة بين منوسط درجات الطلاب في المجمو عات الثلاث في مستوى الفهر

\begin{tabular}{|c|c|c|c|c|c|}
\hline مستوى الدلالة & الاحتمال & $\mathbf{Q}$ & $\mathbf{P}$ & المتوسطين & المقارنة \\
\hline دالة & $<\cdot \cdots 1$ & 1.091 & $r$ & 1.049 & المجموعة التجريبية الأولى - الضموعة الضطة \\
\hline دالة & $\because \leqslant 1$ & $r . \leqslant Y V$ & $r$ & 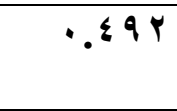 & المجموعة التجريبية الأولى - التجية \\
\hline دالة & $<\bullet \cdots 1$ & $V .1 \leq 0$ & $r$ & $1 . r v$ & المجموعة التجريبية الثانيةة - الضيطة \\
\hline
\end{tabular}

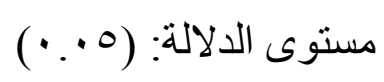

يتضح من الجدول (T I ) أن الفروق بين المجموعة التجريبية الأولى والمجموعة الضابطة ذات دلالة إحصائية عند مستوى الفهم لصالح المجموعة التجريبية الأولى، وهذا قد يرجع لما توافر للمجموعة التجريبية الأولى التي درست باستخدام التكامل بين إستر اتيجيتي التعلم التعاوني والتعلم الذاتي من بيئة تعليمية ساعدت المتعلمين على استقبال المعلومات والأفكار المتضمنة في المادة التعليمية وفهمها وترجمتها وتفسير ها والاستفادة منها بشكل أفضل وأكبر مما توافر للمجموعة 
الضابطة التي درست باستخدام إستر اتيجية المحاضرة العادية، كما أن هنالك فروق ذات دلالة إحصائية بين المجموعة التجريبية الثانية التي درست باستخدام إستر اتيجية المحاضرة المعدلة وبين المجمو عة الضابطة التي درست باستخدام إستر اتيجية المحاضرة العادية عند مستوى الفهم لصالح المجموعة التجريبية الثانية؛ وهذا يعني أن الاختلاف بين استراتيجي التدريس أثر في مستوى فهم المتعلمين للمادة العلمية المتضمنة بالمقرر؛ وأن إستر اتيجية المحاضرة المعدلة قد أناحت بيئة للتعلم و الفهم أفضل من إستر اتيجية المحاضرة العادية من حيث المشاركة وحرية التعبير، أما الفروق بين المجموعتين التجريبيتين والتي كانت ذات دلالة إحصائية عند مستوى الفهم لصالح المجموعة التجرييية الأولى كما يتضح من الجدول؛ فيرجعه الباحث إلى أن كلاً من المجموعتين التجريييتين المجمو عة التي درست باستخدام التكامل بين إستر اتيجيتي التعلم التعاوني والتعلم الذاتي و المجمو عة التي درست باستخدام إستراتيجية المحاضرة المعدلة قد أتاحا فرصا أفضل للفهم والتفسير و الاستكمال وبدرجات مختلفة بين المجمو عتين التجريبيتين تفوقت فيه المجمو عة التجريبية الأولى على التجريبية الثانية؛ لكنه في المجموعة التجريبية الثانية كان أيضا بدرجة أكبر مما أتيح للمجموعة الضابطة التي درست باستخدام إستر اتيجية المحاضرة العادية، ومن ذلك فإنه: - توجد فروق ذات دلالة إحصائية عند مستوى دلالة (0.05) بين كل من المجموعة التجريبية الأولى التي درست باستخدام التكامل بين إستراتيجيتي التعلم التعاوني والتعلم الذاتي و المجموعة التجريبية الثانية التي درست باستخدام إستر اتيجية المحاضرة المعدلة عند مستوى الفهم من الاختبار التحصيلي لاى طلاب كلية الثربعة بجامعة الإمام في مقرر المناهج وطرق التدريس لصالح المجموعة التجريبية الأولى. - توجد فروق ذات دلالة إحصائية عند مستوى دلالة (0.05) بين المجموعة التجريبية الثانية التي درست باستخدام إستراتيجية المحاضرة المعدلة والمجموعة الضابطة التي درست باستخدام إستر اتيجية المحاضرة العادية عند مستوى الفهم من الاختبار التحصيلي لاى طلاب كلية الثريعة بجامعة الإمام في مقرر المناهج وطرق التدريس لصالح المجموعة التجريبية الثانية. - توجد فروق ذات دلالة إحصائية عند مستوى دلالة (0.05) بين كل من المجموعة التجريبية الأولى التي درست باستخدام التكامل بين إستراتيجيتي التعلم التعاوني والتعلم الذاتي والمجموعة الضابطة التي درست باستخدام إستراتيجية المحاضرة العادية عند 
مستوى الفهم من الاختبار التحصيلي لدى طلاب كلية الثريعة بجامعة الإمام في مقرر

$$
\text { المناهج وطرق التدريس لصالح المجموعة التجريبية الأولى. }
$$

" لا توجد فروق ذات دلالة إحصائية عند مستوى دلالة (0 . • ) بين كل من المجموعة التجريبية الأولى التي درست باستخدام التكامل بين إستر اتيجيتي التعلم التعاوني والتعلم الذاتي والمجموعة التجريبية الثانية التي درست باستخدام إستر اتيجية المحاضرة المعدلة وبين المجمو عة الضابطة التي درست باستخدام إستر اتيجية المحاضرة العادية في درجات مستوى التطبيق من الاختبار التحصيلي لدى طلاب كلية الثريعة بجامعة الإمام في مقرر المناهج وطرق التدريس "، قام الباحث بحساب المتوسط الحسابي و الانحر اف المعياري لكل مجمو عة ومقارنة الفروق بينها باستخدام اختبار تحليل التباين الأحادي أنوفا بعد التحقق من صلاحية البيانات لذلك الاختبار، وتبين أن الفروق بين المتوسطات لبست دالة إحصائيا عند مستوى (0. . ) في مستوى التطبيق، كما يتضح ذلك في

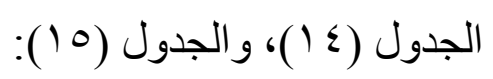

جدول (ع ا ) يبين المتوسط الحسابي و الانحر اف المعياري لكل من المجمو عات الثلاث في مستوى

\begin{tabular}{|c|c|c|c|}
\hline الاتحراف المعياري & المتوسط الحسابي & 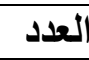 & اسم المجموعة \\
\hline$\cdot .971$ & $1 . \wedge 7 \mathrm{~V}$ & $\leqslant 0$ & المجموعة التجريبية الثانية \\
\hline.$\wedge \wedge r$ & $1.9 \vee \wedge$ & $\leqslant 7$ & المجموعة التجريبية الأولى \\
\hline..$\wedge 1 \mathrm{~V}$ & Y.YVT & $\varepsilon \varepsilon$ & المحمو عة الضابطة \\
\hline
\end{tabular}
التطبيق

يتضح من الجدول (§ 1) وجود فروق بين المتوسطات الحسابية للمجمو عات الثلاث في مستوى التطبيق من الاختبار التحصيلي، و لاختبار دلالة تلك الفروق استخدم الباحث اختبار تحليل التباين باتجاه و احد، وتبين أنها ليست دالة إحصائيا، كما يوضح ذلك الجدول (0 1): جدول (0 1) يبين دلالة الفروق بين متوسطات درجات الطلاب في المجمو عات الثلاث في مستوى

\begin{tabular}{|c|c|c|c|c|c|}
\hline الاحتمال & قيمة ف & متوسطات المربعات & المربعات & درجة الحرية & مصدر التباين \\
\hline \multirow[t]{3}{*}{$\because 199$} & r. $\{09$ & 1.900 & 7.9 .9 & $r$ & بين المجموعات \\
\hline & & .890 & $1.8 .9 \cdot 7$ & Irr & داخل المجموعات \\
\hline & & & $1.1 . \wedge 10$ & $1 \mu \varepsilon$ & المجموع \\
\hline
\end{tabular}
التطبيق

مستوى الدلالة (0. (•) 
يتضح من جدول (0 10) عدم دلالة الفروق بين منوسط درجات الطلاب في المجمو عات الثلاث في مستوى التطبيق دن الاختبار التحصيلي عند مستوى (0. • )، وهذا بعني تكافؤ الإستراتيجيات الثلاث في الأثر في مستوى التطبيق رغم الأفضلية النسبية لمتوسط درجات طلاب المجموعتين التجريبيتين وهذا قد يرجع إلى اهتمام طلاب المجموعات الثلاث باستخدام وتطبيق المعلومات و الأفكار و المفاهيم و المبادئ التي تعلمو ها في مواقف جديدة، وقد يعود هذا إلى طبيعة المتعلمين في كلية الثريعة فحرصهم واهتمامهم بتطبيق ما تعلموه واضح بالملاحظة ـ وهو ما يميز غالب المتعلمين فيها -، وقد يكون هذا التكافؤ بين المجموعات الثلاث في هذا المستوى من الاختبار التحصيلي مرده إلى طبيعة الأسئلة و عددها في الاختبار ، ومن ذلك فإنه: - لا توجد فروق ذات دلالة إحصائية عند مستوى دلالة (0.05) بين كل من المجموعات الثناث وذلك في درجات مستوى التطبيق من الاختبار التحصيلي لدى طلاب كلية الثريعة

$$
\text { بجامعة الإمام في مقرر المناهج وطرق التدريس. }
$$

" لا توجد فروق ذات دلالة إحصائية عند مستوى دلالة (0. . ) بين كل من المجموعة التجريبية الأولى التي درست باستخدام التكامل بين إستر اتيجيتي التعلم التعاوني و التعلم الذاتي و المجموعة التجريبية الثانية التي درست باستخدام إستر اتيجية المحاضرة المعدلة وبين المجموعة الضابطة التي درست باستخدام إستر اتيجية المحاضرة العادية في درجات مستوى التحليل من الاختبار التحصيلي لدى طلاب كلية الثريعة بجامعة الإمام في مقرر المناهج وطرق التدريس "، قام الباحث بحساب المتوسط الحسابي والانحر اف المعياري لكل مجمو عة ومقارنة الفروق بينها باستخدام اختبار تحليل التباين الأحادي أنوفا بعد التحقق من صلاحية البيانات لذلك الاختبار، وتبين أن الفروق بين

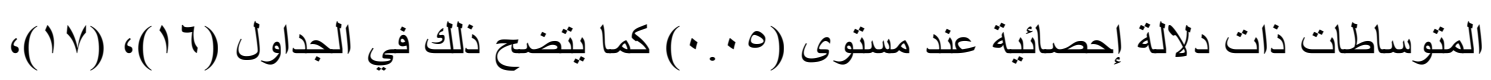
ولتحديد موضع هذه الفروق تم استخدام اختبار توكي للمقارنات المتعددة بين متوسط درجات الطلاب في المجمو عات الثلاث في مستوى التحليل، كما يوضح ذلك الجدول (1 ( ): جدول (7 ا ) يبين المتوسط الحسابي الانحر اف المعياري لدرجات الطلاب في المجموعات الثلاث في مستوى التحليل

\begin{tabular}{|c|c|c|c|}
\hline الانحراف المعياري & المتوسط الحسابي & العدد العد & اسم المجموعة \\
\hline$\because V Y$ & Y.VTr & $\leqslant 0$ & المجموعة التجريبية الثانية \\
\hline$\because \wedge Y \Delta$ & Y.AYY & $\leqslant 7$ & المجموعة التجريبية الأولى \\
\hline.$\wedge \vee Y$ & Y.YVT & $\varepsilon \varepsilon$ & المجموعة الضابطة \\
\hline
\end{tabular}


يتضح من الجدول (7 (1) وجود فروق بين المتوسطات الحسابية للمجمو عات الثناث في مستوى التحليل من الاختبار التحصيلي، ولاختبار دلالة تلك الفروق استخدم الباحث اختبار تحليل التباين

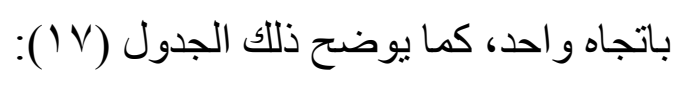

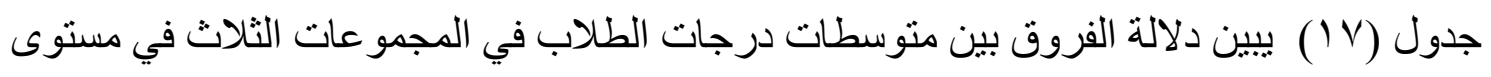
التحليل

\begin{tabular}{|c|c|c|c|c|c|}
\hline الاحتمال & قيمة ف & متوسطات المربعات & مجموع المربعات & درجة الحرية & مصدر التباين \\
\hline$\because \cdot r$ & $7 . \cdots r$ & r.qIV & V.Arz & $r$ & بين المجموعات \\
\hline & &. .704 & A7.1M & ITr & داخل المجموعات \\
\hline & & & $94.9 V$. & $1 \pi \varepsilon$ & المجموع \\
\hline
\end{tabular}

يتضح من الجدول (V V ) أن الفروق بين المتوسطات ذات دلالة إحصائية عند مستوى اكبر من (0.. ) ولتحديد موضع تللك الفروق استخدم الباحث اختبار نوكي للمقارنات المتعددة بين

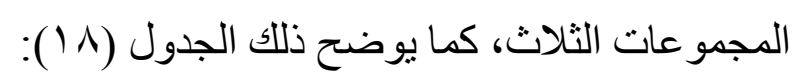
جدول (1/ () يبين نتائج اختبار توكي للمقارنات المتعددة بين متوسط درجات الطلاب في المجمو عات الثلاث في مستوى التحليل

\begin{tabular}{|c|c|c|c|c|c|}
\hline مستوى الدلالة & الاحتمال & $\mathbf{Q}$ & $\mathbf{P}$ & المترق بين & المقارنة \\
\hline دالة & $\because \cdots r$ & $1.09 \varepsilon$ & $r$ & $.00 r$ & المجموعة التجريبية الأولى - المجمة \\
\hline غير دالة & $\because \wedge \leq \wedge$ & $\because \mathrm{VV} \varepsilon$ & $r$ & $\because .94 \wedge$ & المجموعة التجريبية الأولى - التجية \\
\hline دالة & $\because r$. & $r . \Lambda \cdot r$ & $r$ &. .271 & المجموعة التجريبية الثانية - المجابطة \\
\hline
\end{tabular}

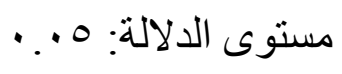

يتضح من الجدول (1) (1) وجود فروق ذات دلالة إحصائية عند مستوى التحليل بين المجموعة التجريبية الأولى التي درست باستخدام التكامل بين إستراتيجيتي التعلم التعاوني والتعلم الذاتي داتي

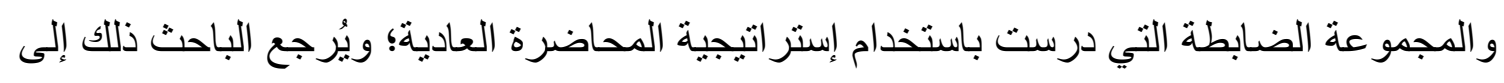
أن ما تم من بيئة تفاعلية وما حصل من بحث ونقاش باستخدام التكامل بين التعلم التعاوني و التعلم

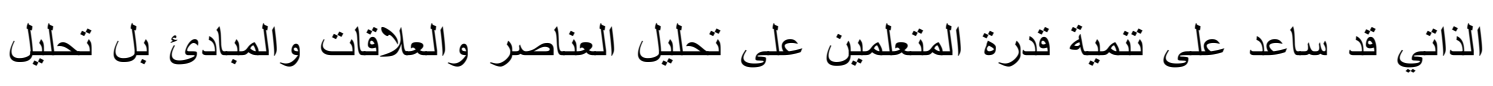

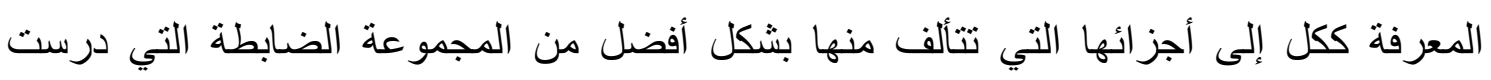

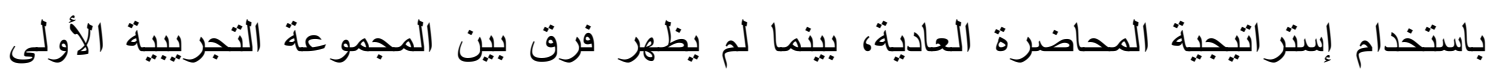


و المجموعة التجريبية الثانية مما يعني تكافؤ المجموعتين التجريبيتين من حيث الأثر في تنمية مستوى التحليل؛ وهذا مؤشر على أن الاستر اتيجيتين المستخدمتين في التجربتين كلتيهما بنميان وبدرجة متساوية مستوى التحليل؛ وبشكل بساعد المتعلمين على تحليل المعرفة بحيث يتضح لايهم الترتيب الهرمي للأفكار و المعاني والعلاقات بينها، كما يُظهر الجدول وجود فرق بين المجموعة التجريبية الثانية التي درست باستخدام إستراتيجية المحاضرة المعدلة والمجموعة الضابطة التي درست باستخدام إستر اتيجية المحاضرة العادية؛ و هذا يعني أن تنمية قدرة المتعلمين على تحليل العناصر و العلاقات و المبادئ بل تحليل المعرفة ككل إلى أجز ائها التي تتألف منها قد تحققت بدرجة أكبر عند استخدام إستر اتيجية المحاضرة المعدلة منها عندما استخدمت إستر اتيجية المحاضرة العادية، ومن ذلك فإنه: - لا توجد فروق ذات دلالة إحصائية عند مستوى دلالة (0.05) بين المجموعة التجريبية الأولى التي درست باستخدام التكامل بين إستراتيجيتي التعلم التعاوني والتعلم الذاتي و المجموعة التجريبية الثانية التي درست باستخدام إستراتيجية المحاضرة المعدلة في درجات مستوى التحليل من الاختبار التحصيلي لاى طلاب كلية الثريعة بجامعة الإمام في مقرر المناهج وطرق التدريس. - توجد فروق ذات دلالة إحصائية عند مستوى دلالة (0.05) بين كل من المجموعة التجريبية الأولى التي درست باستخدام التكامل بين إستراتيجيتي التعلم التعاوني والتعلم الذاتي والمجموعة الضابطة التي درست باستخدام إستراتيجية المحاضرة العادية في درجات مستوى التحليل من الاختبار التحصيلي لدى طلاب كلية الثريعة بجامعة الإمام في مقرر المناهج وطرق التدريس لصالح المجموعة التجريبية الأولى. ـ ـ توجد فروق ذات دلالة إحصائية عند مستوى دلالة (0.05) بين المجموعة التجريبية الثانية التي درست باستخدام إستر اتيجية المحاضرة المعدلة و المجموعة الضابطة التي درست باستخدام إستر اتيجية المحاضرة العادية في درجات مستوى التحليل من الاختبار التحصيلي لاى طلاب كلية الثريعة بجامعة الإمام في مقرر المناهج وطرق التدريس لصالح المجمو عة التجريبية الثانية.

"لا توجد فروق ذات دلالة إحصائية عند مستوى دلالة (0 . • ) بين كل من المجموعة التجريبية الأولى التي درست باستخدام التكامل بين إستراتيجيتي التعلم التعاوني والتعلم الذاتي والمجموعة 
التجريبية الثانية التي درست باستخدام إستر اتيجية المحاضرة المعدلة وبين المجموعة الضابطة التي درست باستخدام إستر اتيجية المحاضرة العادية في درجات مستوى التركيب من الاختبار التحصيلي لاى طلاب كلية الثريعة بجامعة الإمام في مقرر المناهج وطرق التدريس "، قام الباحث بحساب المتوسط الحسابي و الانحر اف المعياري لكل مجموعة ومقارنة الفروق بينها باستخدام اختبار تحليل التباين الأحادي أنوفا بعد التحقق من صلاحية البيانات لذلك الاختبار، وتبين أن الفروق بين المتوسطات ليست دلالة إحصائيا عند مستوى (0.. ) في المجموعات الثلاث في مستوى التركيب، ويتضح ذلك من الجدول (9 ( )، و الجدول (· (ץ) : جدول (9 ( ) بيين المتوسط الحسابي الانحر اف المعياري لدرجات الطلاب في المجمو عات الثلاث في مستوى التركيب

\begin{tabular}{|c|c|c|c|}
\hline الانحر اف المعياري & المتوسط الحسابي & 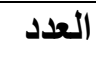 & اسم المجموعة \\
\hline$. .7 Y \leq$ & $1.0 \ldots$ & $\leqslant 7$ & المجموعة التجريبية الأولى \\
\hline. $.7 \wedge \wedge$ & $1.7 \ldots$ & $\leqslant 0$ & المجموعة التجريبية الثانية \\
\hline. .871 & 1.200 & \& & المحمو عة الضابطة \\
\hline
\end{tabular}

يتضح من الجدول (9 (1) وجود فروق بين المتوسطات الحسابية للمجموعات الثنلاث في مستوى التركيب من الاختبار التحصيلي، ولاختبار دلالة تلك الفروق استخدم الباحث اختبار تحليل التباين باتجاه و احد الاختبار ، وتبين أنها ليست دالة احصائيا، كما يوضح ذلك الجدول (· (؟): جدول ( • ب) بيين دلالة الفروق بين منوسطات درجات الطلاب في المجمو عات الثناث في مستوى التركيب

\begin{tabular}{|c|c|c|c|c|c|}
\hline الاحتمال & قيمة ف & متوسطات المربعات & المربعات & درجة الحرية & مصدر التباين \\
\hline \multirow[t]{3}{*}{.091} & .017 & $. r \leqslant V$ & $\therefore \leqslant 90$ & r & بين المجمو عات \\
\hline & & $\because \leqslant \vee q$ & $7 r .9$ & ITY & داخل المجمو عات \\
\hline & & & Tr.V. & $1 \Gamma \varepsilon$ & المجموع \\
\hline
\end{tabular}

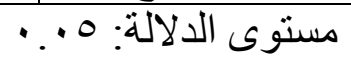

يتضح من جدول (· (Y) عدم دلالة الفروق بين متوسط درجات الطلاب في المجموعات الثلاث في مستوى التركيب من الاختبار التحصيلي عند مستوى (0. • )، وهذا يعني تكافؤ الإستر اتيجيات الثلاث في الأثر في مستوى التركيب، وهذا قد يرجع إلى قدرة طلاب المجموعات الثلاث على التأليف بين العناصر و الأجزاء بحيث تشكل بنية جديدة، وقد يعود هذا إلى طبيعة المتعلمين في كلية 
الثريعة فحرصهم واهتمامهم بالتعامل مع الوحدات و الأجز اء و العناصر وترتيبها و الربط بينها و

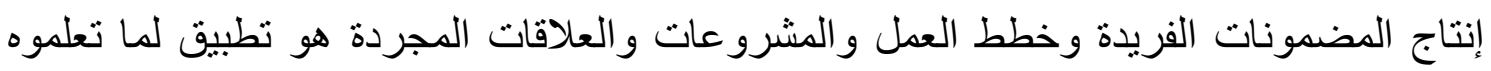

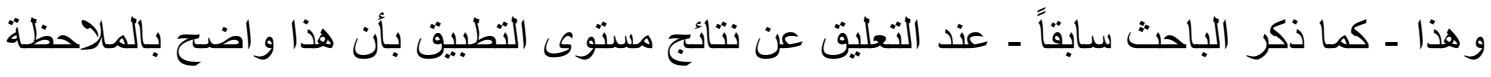

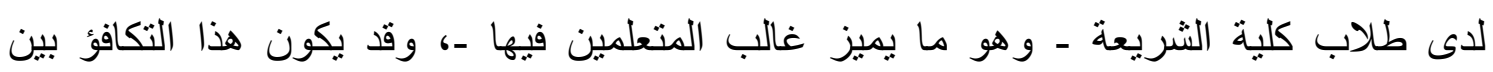
المجمو عات الثلاث في هذا المستوى من الاختبار التحصيلي مرده أيضا إلى طبيعة الأسئلة وعددها في الاختبار المعد لهذه التجربة ونوعية النشاط فيها، ومن ذللك فإنه:

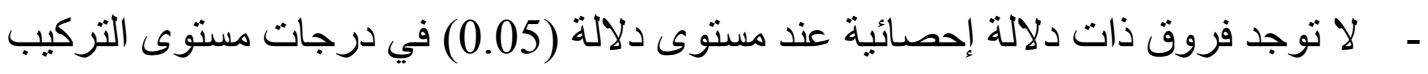

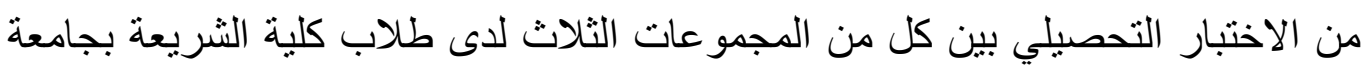

$$
\text { الإمام في مقرر المناهج وطرق التدريس. }
$$

"لا توجد فروق ذات دلالة إحصائية عند مستوى دلالة (0. . ) بين كل من المجموعة التهوفي لتجريبية

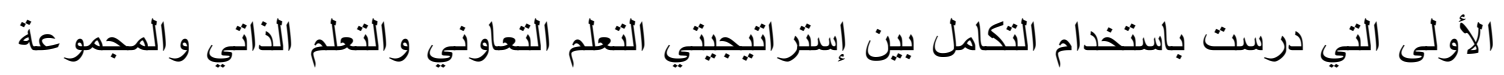

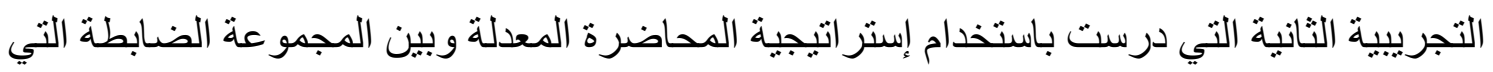

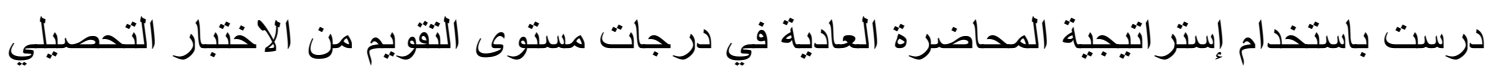

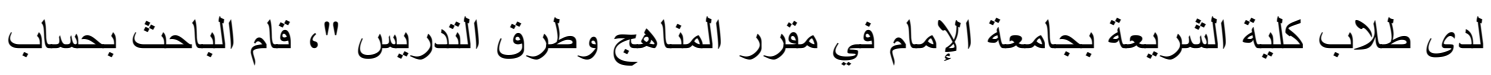
المتوسط الحسابي و الانحر اف المعياري لكل مجمو عة ومقارنة الفروق بينها باستخدام اختبار تحليل

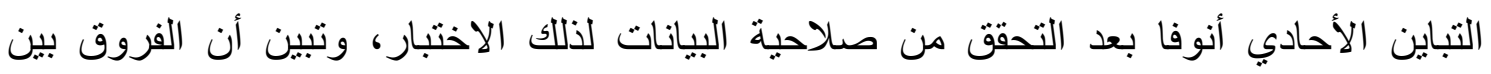

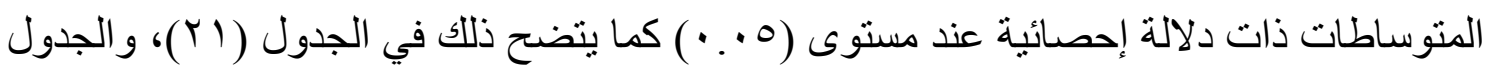

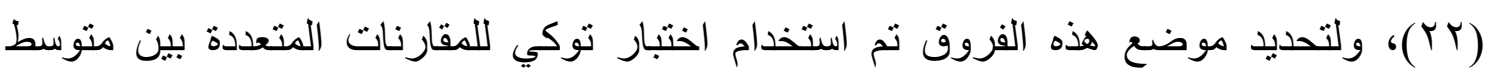

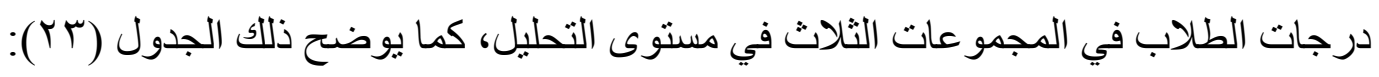

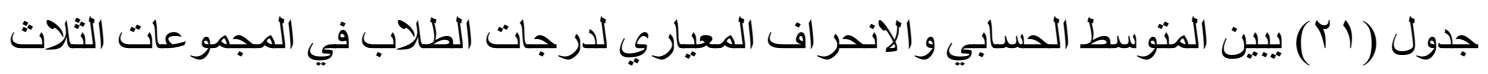
في مستوى التقويم

\begin{tabular}{|c|c|c|c|}
\hline الانحراف المعياري & المتوسط الحسابي & العدد & اسم المجموعة \\
\hline$\cdot . \wedge 79$ & T. $\leqslant T V$ & $\leq 0$ & المجموعة التجريبية الثانية \\
\hline$\because \vee \vee \vee V$ & r.AYT & $\leqslant 7$ & المجموعة التجريبية الأولى \\
\hline $1 . \Delta r$ & 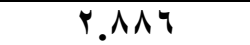 & $\varepsilon \varepsilon$ & المجموعة الضابطة \\
\hline
\end{tabular}


يتضح من الجدول (Yl) وجود فروق بين المتوسطات الحسابية للمجمو عات الثلاث في مستوى التقويم من الاختبار التحصيلي، و لاختبار دلالة تلك الفروق استخدم الباحث اختبار تحليل التباين باتجاه و احد، كما يوضح ذلك الجدول (Yr): جدول(Y Y يبين دلالة الفروق بين منوسطات درجات الطلاب في المجمو عات الثلاث في مستوى التقويم

\begin{tabular}{|c|c|c|c|c|c|}
\hline الاحتمال & قيمة ف & متوسطات المربعات & مجموع المربعات & الحرجة & مصدر التباين \\
\hline \multirow[t]{3}{*}{$<\cdot \cdots 1$} & $11 . \wedge 0 \leq$ & $1 \cdot . \cdot 1$. & $r \cdot .109$ & r & بين المجموعات \\
\hline & & $\because \wedge 0$. & IIY.r\&1 & ITY & داخل المجموعات \\
\hline & & & ITY.E. & ITE & المجموع \\
\hline
\end{tabular}

يتضح من الجدول (Y (Y) أن الفروق بين المتوسطات ذات دلالة إحصائية عند مستوى (0. . )، ولتحديد موضع تللك الفروق استخدم الباحث اختبار نوكي للمقارنات المتعددة بين المجموعات الثلاث، كما يوضح ذلك الجدول (rT): جدول (Tr) يبين نتائج اختبار توكي للمقارنات المتعددة بين منوسط درجات الطلاب في المجمو عات الثلاث في مستوى التقويم

\begin{tabular}{|c|c|c|c|c|c|}
\hline الدالة & الاحتمال & $\mathbf{Q}$ & $\mathbf{P}$ & المتوسطين & المقارنة \\
\hline دالة & $<\cdots \cdots 1$ & 7.ATO & $\mu$ & $\cdot .9 \leq$ & المجموعة التجريبية الأولى - المجموعة \\
\hline غير دالة & .101 & r.7 rq & $\mu$ & $\because r \Delta q$ & المجموعة التجريبية الأولى ـ المجموعة \\
\hline دالة & $\because \cdots 1$ & $\varepsilon .191$ & $r$ & $.0 \wedge$. & المجموعة التجريبية الثانية ــ المجموعة \\
\hline
\end{tabular}

يتضح من الجدول (YM) وجود فروق ذات دلالة إحصائية عند مستوى التقويم بين المجموعة التجريبية الأولى التي درست باستخدام التكامل بين إستراتيجيتي التعلم التعاوني والتعلم الذاتي و المجمو عة الضابطة التي درست باستخدام إستر اتيجية المحاضرة العادية؛ ويُرجع الباحث ذللك إلى أن ما تم من بيئة تفاعلية وما حصل من بحث ونقاش و إعداد و عرض باستخدام التكامل بين التعلم التعاوني والتعلم الذاتي قد ساعد على تنمية قدرة المتعلمين على الحكم على قيمة المادة العلمية ومو اقفهم طبقا لأفكار محدة لتحقيق الأهداف وتقييمها بشكل أفضل من المجموعة الضابطة التي 
درست باستخدام إستر اتيجية المحاضرة العادية، بينما لم يظهر فرق بين المجمو عة التجريبية الأولى و المجموعة التجريبية الثانية مما يعني تكافؤ المجمو عتين التجريبيتين من حيث الأثر في تنمية مستوى التقويم؛ وهذا مؤشر على أن الاستراتيجيتين المستخدمتين في التجربتين كلتيهما ينميان وبدرجة منساوية مستوى التقويم؛ وبشكل يساعد المتعلمين على الحكم على المادة العلمية وتقويمها، كما يُظهر الجدول وجود فرق بين المجموعة التجريبية الثانية التي درست باستخدام إستر اتيجية المحاضرة المعدلة و المجموعة الضابطة التي درست باستخدام إستر اتيجية المحاضرة العادية؛ وهذا يعني أن تنمية قدرة المتعلمين على الحكم على المادة العلمية وتقويمها قد تحققت بدرجة أكبر عند استخدام إستر اتيجية المحاضرة المعدلة منها عندما استخدمت إستر اتيجية المحاضرة العادية، ومن

- لا توجد فروق ذات دلالة إحصائية عند مستوى دلالة (0.05) بين المجموعة التجريبية الأولى التي درست باستخدام التكامل بين إستراتيجيتي التعلم التعاوني والتعلم الذاتي و المجموعة التجريبية الثانية التي درست باستخدام إستراتيجية المحاضرة المعدلة في درجات مستوى التقويم من الاختبار التحصيلي لدى طلاب كلية الثريعة بجامعة الإمام في مقرر المناهج وطرق التدريس. - توجد فروق ذات دلالة إحصائية عند مستوى دلالة (0.05) بين كل من المجموعة التجريبية الأولى التي درست باستخدام التكامل بين إستراتيجيتي التعلم التعاوني والتعلم الذاتي والمجموعة الضابطة التي درست باستخدام إستراتيجية المحاضرة العادية في درجات مستوى التقويم من الاختبار التحصيلي لدى طلاب كلية الثريعة بجامعة الإمام في مقرر المناهج وطرق التدريس لصالح المجموعة التجريبية الأولى. - توجد فروق ذات دلالة إحصائية عند مستوى دلالة (0.05) بين المجموعة التجريبية الثانية التي درست باستخدام إستر اتيجية المحاضرة المعدلة و المجموعة الضابطة التي درست باستخدام إستر اتيجية المحاضرة العادية في درجات مستوى التقويم من الاختبار التحصيلي لاى طلاب كلية الثريعة بجامعة الإمام في مقرر المناهج وطرق التدريس لصالح المجمو عة التجريبية الثانية. 
ץ- إجابة السؤال الثاني: " ما فاعلية التكامل بين إستراتيجيتي التعلم التعاوني والتعلم الذاتي و استخدام إستر اتيجية المحاضرة المعدلة مقارنة باستخدام إستر اتيجية المحاضرة العادية في تنمية التحصيل لدى طلاب كلية الثريعة بجامعة الإمام في مقرر المناهج وطرق التدريس؟ للإجابة على السؤال الثاني تم اختبار صحة الفرض الثاني، كما يلي: لاختبار صحة الفرض الثاني: " لا توجد فروق ذات دلالة إحصائية عند مستوى دلالة (0. . ) بين كل من المجموعة التجريبية الأولى التي درست باستخدام التكامل بين إستراتيجيتي التعلم التعاوني و التعلم الذاتي والمجموعة التجريبية الثانية التي درست باستخدام إستراتيجية المحاضرة المعدلة وبين المجموعة الضابطة التي درست باستخدام إستراتيجية المحاضرة العادية في درجات المستويات الدنيا من الاختبار التحصيلي لاى طلاب كلية الثريعة بجامعة الإمام في مقرر المناهج وطرق التدريس " قام الباحث بحساب المتوسط الحسابي والانحر اف المعياري لكل مجموعة ومقارنة الفروق بينها باستخدام اختبار تحليل التباين الأحادي أنوفا بعد التحقق من صلاحية البيانات لذلك الاختبار، وتبين أن الفروق بين المتوساطات ذات دلالة إحصائية عند مستوى (0. . •)، كما يتضح ذلك في الجدول (乏Y)، والجدول (Y))، ولتحديد موضع هذه الفروق تم استخدام اختبار توكي للمقارنات المتعددة بين متوسط درجات الطلاب في المجمو عات الثلاث في المستويات الدنيا، كما يوضح ذلك الجدول (Tr): جدول (§؟Y) يبين المتوسط الحسابي و الانحر اف المعياري لدرجات الطلاب في المجموعات الثلاث في المستويات الدنيا

\begin{tabular}{|c|c|c|c|}
\hline الانحر اف المعباري & المتوسط الحسابي & 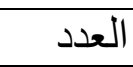 & اسم المجمو عة \\
\hline $1.10 \leqslant$ & V.Y.. & $\leqslant 0$ & المجمو عة التجرييية الثانية \\
\hline$r .1 \varepsilon$ & 1.1 .9 & $\leqslant 7$ & المجمو عة التجريبية الأولى \\
\hline 1.191 & T.YYV & $\varepsilon \varepsilon$ & المجمو عة الضابطة \\
\hline
\end{tabular}
المستويات الدنيا من الاختبار التحصيلي، ولاختبار دلالة تلك الفروق استخدم الباحث اختبار تحليل التباين باتجاه واحد، كما يوضح ذلك الجدول (Y0): 
جدول(Y0) يبين دلالة الفروق بين متوسطات درجات الطلاب في المجموعات الثلاث في المستويات الدنيا

\begin{tabular}{|c|c|c|c|c|c|}
\hline الاحتمال & قيمة ف & متوسطات المربعات & مجموع المربعات & الدرجة & مصدر التباين \\
\hline \multirow[t]{3}{*}{$<\cdot \cdots 1$} & $1 . \vee \vee \wedge$. & $r q . \wedge \cdot \varepsilon$ & $\vee 9.9 .9$ & $r$ & بين المجموعات \\
\hline & & $r .79 r$ & $\varepsilon \wedge \vee, \Psi \wedge \varepsilon$ & ITr & داخل المجموعات \\
\hline & & & 077.994 & 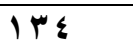 & المجموع \\
\hline
\end{tabular}

يتضح من الجدول (Y0) أن الفروق بين المتوسطات ذات دلالة إحصائية عند مستوى (0. . )، ولتحديد موضع تلك الفروق استخدم الباحث اختبار توكي للمقارنات المتعددة بين المجموعات الثلاث، كما يوضح ذلك الجدول (Tr): جدول (Tr) يبين نتائج اختبار توكي للمقارنات المتعددة بين منتوسط درجات الطلاب في المجمو عات الثناث في المستويات الدنيا من الاختبار التحصيلي

\begin{tabular}{|c|c|c|c|c|c|}
\hline الدلالة & الاحتمال & $\mathbf{Q}$ & $\mathbf{P}$ & المتوسطين & المقارنة \\
\hline دالة & $<\cdot \cdots+$ & $7.07 V$ & $r$ & $1 . \wedge \wedge 1$ & المجموعة التجريبية الأولى - المجموعة \\
\hline غير دالة & $\because 9 r$ & $r .19$. & $r$ & .9 .9 & المجموعة التجريبية الأولى - المجموعة \\
\hline دالة & $\because \leqslant 0$ & r.rVV & $\mu$ & $.9 V 4$ & المجموعة التجريبية الثانية ــ المجموعة \\
\hline
\end{tabular}

يتضح من الجدول (TYY) وجود فروق ذات دلالة إحصائية في المستويات الدنيا بين المجموعة التجريبية الأولى التي درست باستخدام التكامل بين إستر اتيجيتي التعلم التعاوني والتعلم الذاتي و المجمو عة الضابطة التي درست باستخدام إستر اتيجية المحاضرة العادية؛ ويُرجع الباحث ذللك إلى أن ما تم من بيئة تفاعلية وما حصل من بحث ونقاش و إعداد و عرض باستخدام التكامل بين التعلم التعاوني و التعلم الذاتي قد ساعد على تنمية قدرة المتعلمين في المستويات المعرفية الدنيا (التذكر، الفهم، و التطبيق) إجمالا بشكل أفضل من المجموعة الضابطة التي درست باستخدام إستر اتيجية المحاضرة العادية، بينما لم يظهر فرق بين المجموعة التجرييية الأولى والمجمو عة التجريبية الثانية مما بعني تكافؤ المجموعتين التجريبيتين من حيث الأثر في تتمية قدرة المتعلمين في المستويات المعرفية الدنيا (التذكر، الفهم، والتطبيق) إجمالا؛ و هذا مؤشر على أن الاستر اتيجينين المستخدمثين في التجربتين كلتيهما ينميان وبدرجة متساوية مستويات التفكير الدنيا؛ وبشكل يساعد المتعلمين على 
التذكر و الفهم والتطبيق، كما يُظهر الجدول وجود فرق بين المجموعة التجريبية الثانية التي درست باستخدام إستر اتيجية المحاضرة المعدلة والمجموعة الضابطة التي درست باستخدام إستر اتيجية المحاضرة العادية؛ وهذا يعني أن تتمية قدرة المتعمين على التذكر والفهر والتطبيق قد تحققت بدرجة أكبر عند استخدام إستراتيجية المحاضرة المعدلة منها عندما استخدمت إستراتيجية المحاضرة العادية، ومن ذلك فإنه:

- لا توجد فروق ذات دلالة إحصائية عند مستوى دلالة (0.05) بين المجموعة التجريبية الأولى التي درست باستخدام التكامل بين إستراتيجيتي التعلم التعاوني والتعلم الذاتي و المجموعة التجريبية الثانية التي درست باستخدام إستراتيجية المحاضرة المعدلة في درجات المستويات المعرفية الدنيا من الاختبار التحصيلي لدى طلاب كلية الثريعة بجامعة الإمام في مقرر المناهج وطرق التدريس. - توجد فروق ذات دلالة إحصائية عند مستوى دلالة (0.05) بين كل من المجموعة التجريبية الأولى التي درست باستخدام التكامل بين إستراتيجيتي التعلم التعاوني والتعلم الذاتي والمجموعة الضابطة التي درست باستخدام إستراتيجية المحاضرة العادية في درجات المستويات المعرفية الدنيا من الاختبار التحصيلي لدى طلاب كلية الثريعة بجامعة الإمام في مقرر المناهج وطرق التدريس لصالح المجموعة التجريبية الأولى. - توجد فروق ذات دلالة إحصائية عند مستوى دلالة (0.05) بين المجموعة التجريبية الثانية التي درست باستخدام إستراتيجية المحاضرة المعدلة والمجموعة الضابطة التي درست باستخدام إستر اتيجية المحاضرة العادية في درجات المستويات المعرفية الدنيا من الاختبار التحصيلي لدى طلاب كلية الثريعة بجامعة الإمام في مقرر المناهج وطرق التدريس لصالح المجمو عة التجريبية الثانية. "ــ إجابة السؤال الثالث: " ما فاعلية استخدام التكامل بين إستر اتيجيتي التعلم التعاوني و التعلم الذاتي وبين استخدام إستراتيجية المحاضرة المعدلة مقارنة باستخدام إستراتيجية المحاضرة العادية في تنمية التحصيل لاى طلاب كلية الشريعة بجامعة الإمام في مقرر المناهج وطرق التدريس في المستويات المعرفية العلياوفق تصنيف بلوم المعرفي؟ . للإجابة على السؤال الثالث تم اختبار صحة الفرض الثامن، كما يلي: 
لاختبار صحة الفرض الثالث: " لا توجد فروق ذات دلالة إحصائية عند مستوى دلالة (0. . • ) بين كل من المجموعة التجريبية الأولى التي درست باستخدام التكامل بين إستراتيجيتي التعلم التعاوني و التعلم الذاتي والمجموعة التجريبية الثانية التي درست باستخدام إستراتيجية المحاضرة المعدلة وبين المجموعة الضابطة التي درست باستخدام إستر اتيجية المحاضرة العادية في درجات المستويات العليا من الاختبار التحصيلي لدى طلاب كلية الشريعة بجامعة الإمام في مقرر المناهج وطرق التدريس " قام الباحث بحساب المتوسط الحسابي والانحر اف المعياري لكل مجموعة ومقارنة الفروق بينها باستخدام اختبار تحليل التباين الأحادي أنوفا بعد التحقق من صلاحية البيانات لذلك الاختبار، وتبين أن الفروق بين المتوساطات ذات دلالة إحصائية عند مستوى (0. . •)، كما يتضح ذلك في الجداول (YV)، (YN)، ولتحديد موضع هذه الفروق تم استخدام اختبار توكي للمقارنات المتعددة بين متوسط درجات الطلاب في المجموعات الثلاث في المستويات العليا، كما يوضح ذلك الجدول (Y9): جدول (YV) يبين المتوسط الحسابي و الانحر اف المعياري لدرجات الطلاب في المجمو عات الثلاث في المستويات العليا

\begin{tabular}{|c|c|c|c|}
\hline الانحر اف المعياري & المتوسط الحسابي & العدد & اسم المجموعة \\
\hline $1 . r q r$ & $\vee . \wedge \ldots$ & $\leqslant 0$ & المجموعة التجريبية الثانية \\
\hline $1 . \leqslant \leq 0$ & $1.10 Y$ & $\{7$ & المجموعة التجريبية الأولى \\
\hline $1 . \vee 71$ & $7.71 \varepsilon$ & $\varepsilon \varepsilon$ & المجموعة الضابطة \\
\hline
\end{tabular}
يتضح من الجدول (YV) وجود فروق بين المتوسطات الحسابية للمجموعات الثلاث في المستويات العليا من الاختبار التحصيلي، ولاختبار دلالة تلك الفروق استخدم الباحث اختبار تحليل التباين باتجاه واحد، كما يوضح ذلك الجدول (Y^): جدول(Y^) يبين دلالة الفروق بين متوسطات درجات الطلاب في المجموعات الثلاث في المستويات العليا

\begin{tabular}{|c|c|c|c|c|c|}
\hline الاحتمال & قيمة ف & متوسطات المربعات & مجموع المربعات & الرجية & مصدر التباين \\
\hline \multirow[t]{3}{*}{$<\cdot \cdots 1$} & IY.YIO & $r q .+1 V$ & $\Delta \Lambda_{.} \cdot r \mu$ & $r$ & بين المجموعات \\
\hline & & Y.rVT & MIT.0TV & ITY & داخل المجموعات \\
\hline & & & rVI.7... & צ & المجموع الكلي \\
\hline
\end{tabular}


يتضح من الجدول (^^^) أن الفروق بين المتوسطات ذات دلالة احصائية عند مستوى (0 . •)، ولتحديد موضع تللك الفروق استخدم الباحث اختبار نوكي للمقارنات المتعددة بين المجموعات

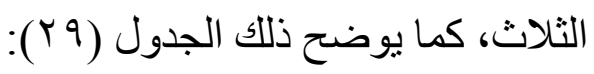

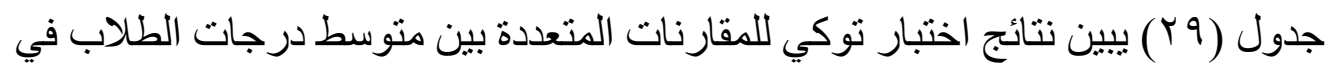

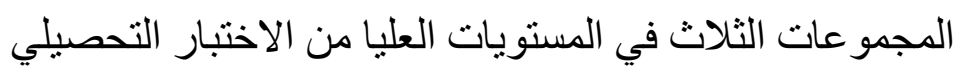

\begin{tabular}{|c|c|c|c|c|c|}
\hline الدلالة & الاحتمال & $\mathbf{Q}$ & $\mathbf{P}$ & المتوسطين & المقارنة \\
\hline دالة & $<\because \cdots)$ & 7.790 & $r$ & 1.049 & المجموعة التجريبية الأولى - المجموعة \\
\hline غير دالة &.$\Delta Y$. & $1.0 \leqslant 1$ & $\mu$ & - TOY & المجموعة التجريبية الأولىئ - المجموعة \\
\hline دالة & $<\because \cdots \mid$ & $0.1 \% \varepsilon$ & $r$ & 1.114 & المجموعة التجريبية الثانية ـ المجموعة \\
\hline
\end{tabular}
مستوى الدلالة: 0. -

يتضح من الجدول (Y9) وجود فروق ذات دلالة إحصائية في المستويات العليا بين المجموعة التجريبية الأولى التي درست باستخدام التكامل بين إستراتيجيتي التعلم التعاوني و التعلم الذاتي

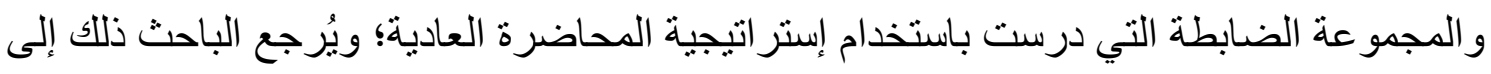
أن ما تم من بيئة تفاعلية وما حصل من بحث ونقاش و إعداد و وعرض باستخدام التكامل بين التعلم التعاوني و التعلم الذاتي قد ساعد على تنمية قدرة المتعلمين في المستويات المعرفية العليا (التحليل، التركيب، التقويم) إجمالا بشكل أفضل من المجموعة الضابطة التي درست باستخدام إستر اتيجية

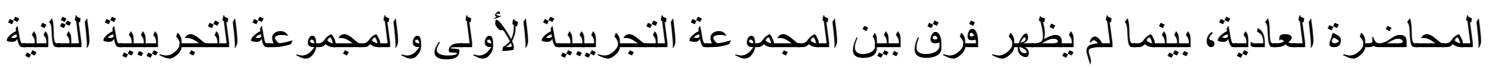
مما يعني تكافؤ المجموعتين التجرييتين من حيث الأثر في تتمية قدرة المتعلمين في المستويات

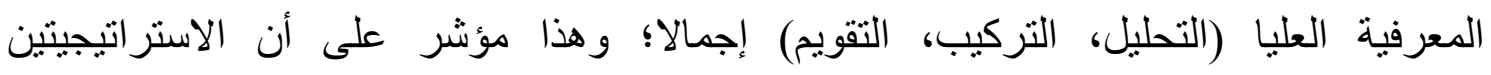

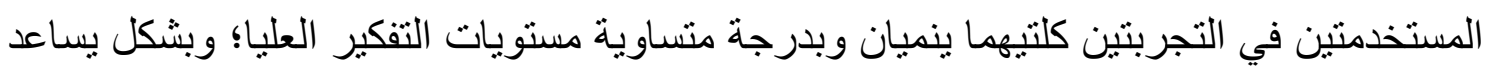

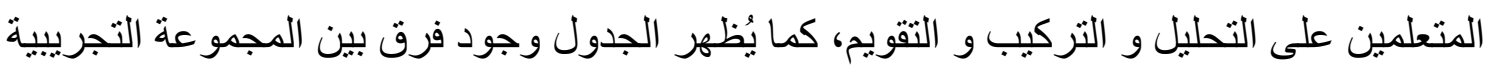

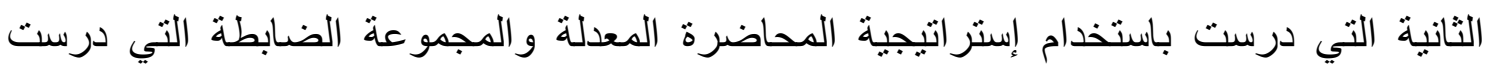
باستخدام إستر اتيجية الدحاضرة العادية؛ وهذا يعني أن تتمية قدرة المتعلمين على التحليل و ولئه

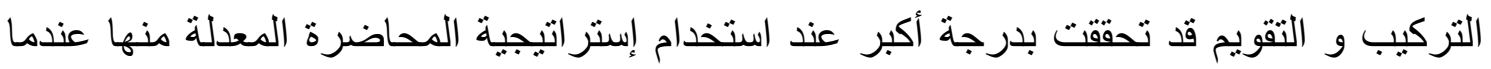
استخدمت إستر اتيجية المحاضرة العادية، ومن ذلك فإنه: 
- ل لا توجد فروق ذات دلالة إحصائية عند مسنوى دلالة (0.05) بين المجموعة التجرييية

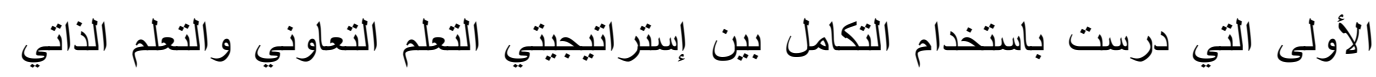

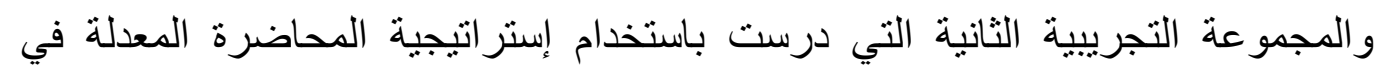

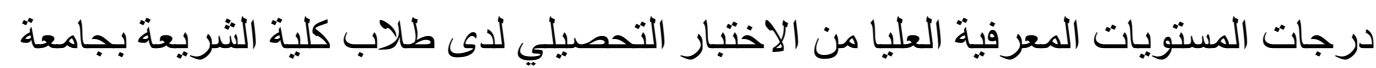
الإمام في مقرر المناهج وطرق التدريس. - توجد فروق ذات دلالة إحصائية عند مستوى دلالة (0.05) بين كل من المجموعة التجريية الأولى التي درست باستخدام التكامل بين إستراتيجيتي التعلم التعاوني والتعلم

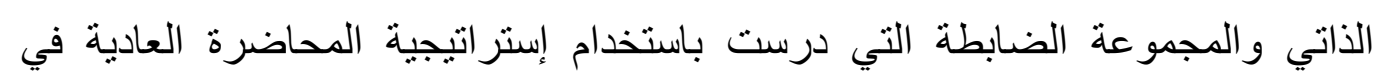

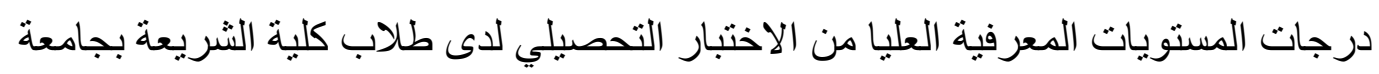
الإمام في مقرر المناهج وطرق التدريس لصالح الهجو عة التجريبية الأولى.

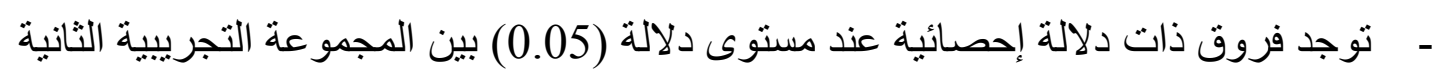

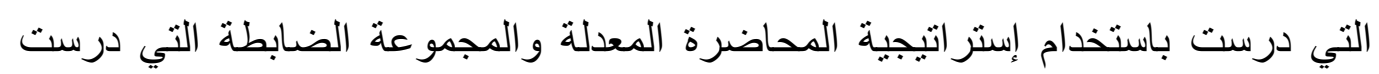
باستخدام إستر اتيجية المحاضرة العادية في درجات المستويات المعرفية العليا من الاختبار

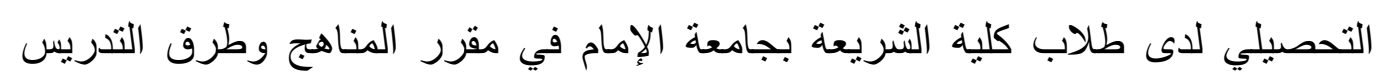
لصالح المجمو عة التجريبية الثانية. rـ إجابة السؤال الر ابع: " ما فاعلية استخدام التكامل بين إستر اتيجيتي التعلم التعاوني و التعلم الذاتي

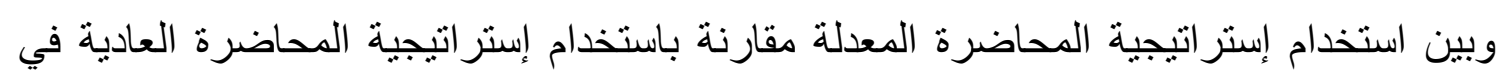

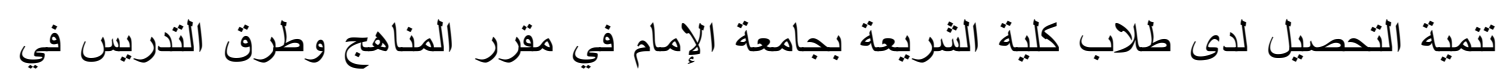
المستويات المعرفية ككل وفق تصنيف بلوم المعرفي؟

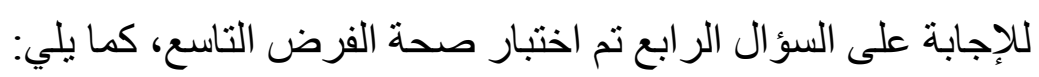

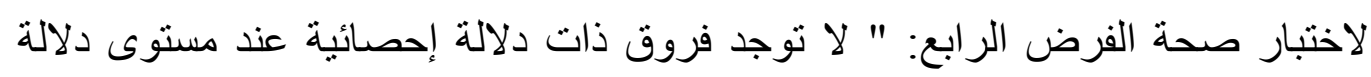
(0. . • ) بين كل من الهجموعة التجريبية الأولى التي درست باستخدام التكامل بين إستراتيجيتي

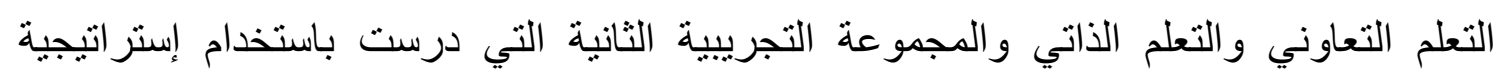
المحاضرة المعلة وبين المجموعة الضابطة التي درست باستخدام إستر اتيجية المحاضرة العادية

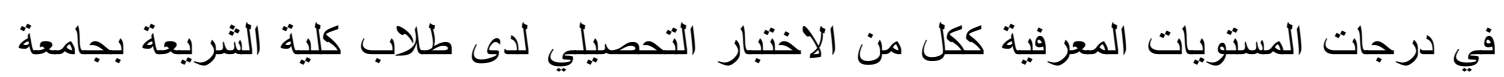

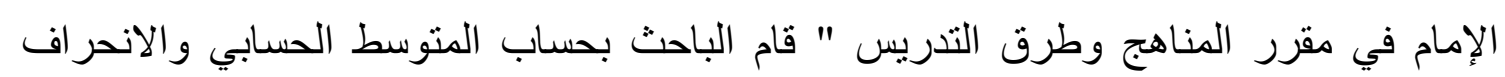


المعياري لكل مجموعة ومقارنة الفروق بينها باستخدام اختبار تحليل التباين الأحادي أنوفا بعد التحقق من صلاحية البيانات لذلك الاختبار، وتبين أن الفروق بين المتوساطات ذات دلالة إحصائية

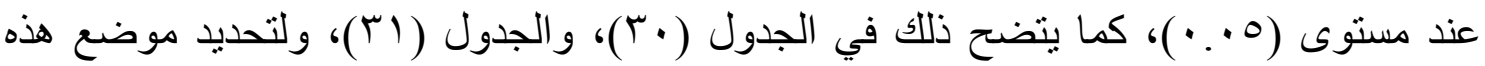
الفروق تم استخدام اختبار توكي للمقارنات المتعددة بين متوسط درجات الطلاب في المجموعات الثلاث في المستويات ككل كما يوضح ذلك الجدول (rr): جدول (• ب) يبين المتوسط الحسابي و الانحر اف المعياري لدرجات الطلاب في المجمو عات الثلاث في المستويات ككل

\begin{tabular}{|c|c|c|c|}
\hline الانحراف المعياري & المتوسط الحسابي & العدد & اسم المجموعة \\
\hline Y.Ort & $10.0 r$ & $\leqslant 0$ & المجموعة التجريبية الثانية \\
\hline Y.A9 & 17.571 & $\$ 7$ & المجموعة التجريبية الأولى \\
\hline Y.TOT & IY.VYV & $\leqslant \varepsilon$ & المجموعة الضابطة \\
\hline
\end{tabular}

يتضح من الجدول (• (ץ) وجود فروق بين المتوسطات الحسابية للمجمو عات الثلاث في المستويات ككل من الاختبار التحصيلي، ولاختبار دلالة تلك الفروق استخدم الباحث اختبار تحليل التباين باتجاه و احد، كما يوضح ذلك الجدول (1):

جدول(ا(ب) يبين دلالة الفروق بين متوسطات درجات الطلاب في المجموعات الثلاث في المستويات ككل

\begin{tabular}{|c|c|c|c|c|c|}
\hline الاحتمال & قيمة ف & متوسطات المربعات & مجموع المربعات & الحرجية & مصدر التباين \\
\hline$<\cdot \cdots 1$ & $19 . V \leq 0$ & $1 \leqslant r .9 \wedge V$ & YAV.qV\& & $r$ & بين المجموعات \\
\hline & & V.YqY & QYY.OV० & ITY & داخل المجموعات \\
\hline & & & $1 Y 0 \cdot .0 \leq 1$ & 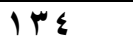 & المجموع الكلي \\
\hline
\end{tabular}

بتضح من الجدول (آ) أن الفروق بين المتوسطات ذات دلالة إحصائية عند مستوى (0.. )، ولتحديد موضع تلك الفروق استخدم الباحث اختبار توكي للمقارنات المتعددة بين المجموعات الثلاث، كما يوضح ذللك الجدول (rr): 
جدول (rr) يبين نتائج اختبار توكي للمقارنات المتعددة بين متوسط درجات الطلاب في المجمو عات الثلاث في المستويات ككل من الاختبار التحصيلي

\begin{tabular}{|c|c|c|c|c|c|}
\hline الدلالة & الاحتمال & $\mathbf{Q}$ & $\mathbf{P}$ & المترسطين & المقارنة \\
\hline دالة & $<\cdots \cdots$ & $\Lambda . \vee \vee T$ & $r$ & $r .0 r \varepsilon$ & المجموعة التجريبية الأولى ـ المجموعة \\
\hline غير دالة & $\because V r$ & r..9 & $r$ & $1 . r+q$ & المجموعة التجريبية الأولى - المجموعة \\
\hline دالة & $<\cdot \cdots 1$ & 0.779 & $\mu$ & Y.YqQ & المجموعة التجريبية الثانية ــ المجموعة \\
\hline
\end{tabular}

مستوى الدلالة: 0 . •

يتضح من الجدول (Yr) وجود فروق ذات دلالة إحصائية عند مستوى (0. . •) في المستويات ككل بين المجموعة التجريبية الأولى التي درست باستخدام التكامل بين إستر اتيجيتي التعلم التعاوني و التعلم الذاتي والمجموعة الضابطة التي درست باستخدام إستر اتيجية المحاضرة العادية؛ ويُرجع الباحث ذللك إلى أن ما تم من بيئة تفاعلية وما حصل من بحث ونقاث وتبادل للأفكار و المعلومات داخل المجمو عة و اعداد وعرض باستخدام التكامل بين التعلم التعاوني والتعلم الذاتي قد ساعد على تتمية قدرة المتعلمين في المستويات المعرفية ككل وتتمية المجال المعرفي بشكل أفضل من المجمو عة الضابطة التي درست باستخدام إستر اتيجية المحاضرة العادية، بينما لم يظهر فرق بين المجمو عة التجريبية الأولى و المجموعة التجريبية الثانية مما يعني تكافؤ المجمو عتين التجريبيتين من حيث الأثر في تنمية قدرة المتعلمين في المستويات المعرفية ككل وتتمية المجال المعرفي بشكل عام؛ وهذا مؤشر على أن الاستراتيجيتين المستخدمتين في التجربتين كلتيهما ينميان وبدرجة متساوية المجال المعرفي بمستوياته الستة بشكل يساعد المتعلمين على تنمية معارفهم، كما يُظهر الجدول وجود فرق بين المجموعة التجريبية الثانية التي درست باستخدام إستراتيجية المحاضرة المعدلة و المجموعة الضابطة التي درست باستخدام إستر اتيجية المحاضرة العادية؛ وهذا بعني أن تتمية معارف المتعلمين قد تحققت بدرجة أكبر عند استخدام إستراتيجية المحاضرة المعدلة منها عندما استخدمت إستر اتيجية المحاضرة العادية، ومن ذلك فإنه: - لا توجد فروق ذات دلالة إحصائية عند مستوى دلالة (0.05) بين المجموعة التجريبية الأولى التي درست باستخدام التكامل بين إستراتيجيتي التعلم التعاوني والتعلم الذاتي و المجموعة التجريبية الثانية التي درست باستخدام إستراتيجية المحاضرة المعدلة في 
درجات المستويات المعرفية الستة ككل في الاختبار التحصيلي لدى طلاب كلية الثريعة

$$
\text { بجامعة الإمام في مقرر المناهج وطرق التدريس. }
$$

- توجد فروق ذات دلالة إحصائية عند مستوى دلالة (0.05) بين كل من المجموعة التجريبية الأولى التي درست باستخدام التكامل بين إستراتيجيتي التعلم التعاوني والتعلم الذاتي والمجموعة الضابطة التي درست باستخدام إستراتيجية المحاضرة العادية في درجات المستويات المعرفية الستة ككل في الاختبار التحصيلي لاى طلاب كلية الثريعة بجامعة الإمام في مقرر المناهج وطرق التدريس لصالح المجموعة التجريبية الأولى. - توجد فروق ذات دلالة إحصائية عند مستوى دلالة (0.05) بين المجمو عة التجريبية الثانية التي درست باستخدام إستر اتيجية المحاضرة المعدلة والمجموعة الضابطة التي درست باستخدام إستراتيجية المحاضرة العادية في درجات المستويات المعرفية الستة ككل في الاختبار التحصيلي لاى طلاب كلية الثريعة بجامعة الإمام في مقرر المناهج وطرق التدريس لصالح المجمو عة التجريبية الثانية. التوصيات: في ضوء النتائج السابقة، فإن الباحث يوصي بما يلي: الاهتمام باستخدام الاستر اتيجيات الحديثة في التدريس ـ كإستر اتيجية التكامل بين إسـتر اتيجيتي التعلم التعاوني و التعلم الذاتي و إستر اتيجية المحاضرة المعدلة كإستر اتيجيتين من إستر اتيجيات التعلم النشط - وذلك لما لهما من أثر في تنميـة التحصيل و إكساب المعـارف و الحقائق العلميـة وتنمية مستويات التفكير لدى الطلاب في المستويات المعرفية بشكل عام. أهميـة التتـوع في اسـتخدام اسـتر اتيجيات التعلم النشـط و الاهتمـام بالاسـتر اتيجيات التدريسية الحديثة التي تساعد على التحصيل وتنمية قدر ات التفكير المختلفة وضـرورة التوسع في مجـال الاستر اتيجيات التكاملية، وتطوير الطرق التوالفية التي تجمع بين أكثر من استر اتيجية واحدة، و أن هذا المنحى يعد بنتـائج إيجابيـة في مجـال تطوير التعليم و مجـال الأبحاث و الدر اسـات التربوية. أهمية عقد ندوات ولقاءات وورش عمل ودورات تدريبيـة لأعضـاء هيئة التدريس وتدريبهم على استخدام الاستر اتيجيات الحديثة في التدريس وبالذات إستر اتيجيات التعلم النشط المختلفة وتجريبها ومقارنتها وخاصة التي تتفق مع حاجـات ومتطلبـات التعليم العـالي وتتو افق وفلسفة 
التعلم النشط، ولاسيما التي تعين على تتمية التحصيل وتزيد القدرة على التفكير السليم و إصدار

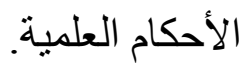
أهميـة الاطلاع وتطبيق مـا تؤكده الدر اسـات التربوية و الكتب المتخصصـة في مجـال أدبيات

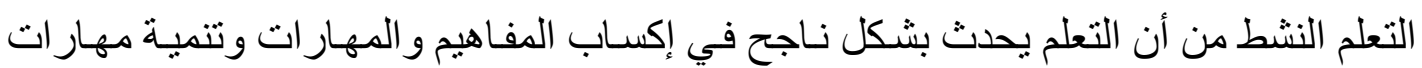

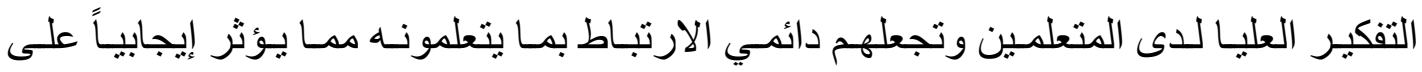

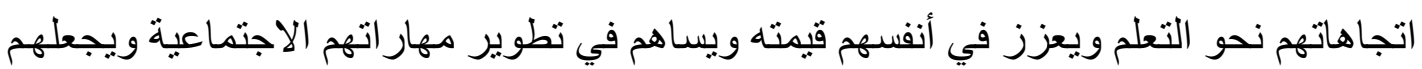

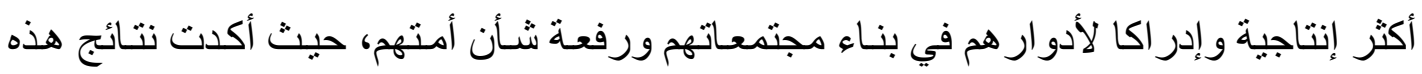

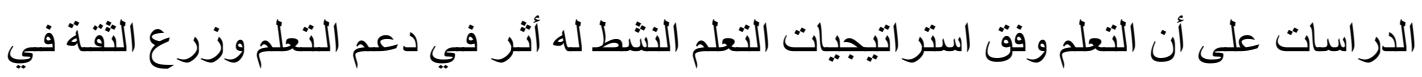
نفوس المتعلمين حيث يتلقون من خلالها الكثير من التثجيع و الدعم عندما يسلمون مسئولية قيادة عمليات التعلم بأنفسهم وتتاح الفرصة لهم لإبداء آر ائهم و العمل بأنفسهم.

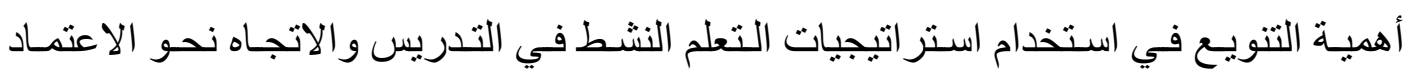

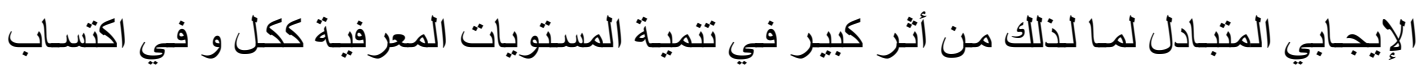

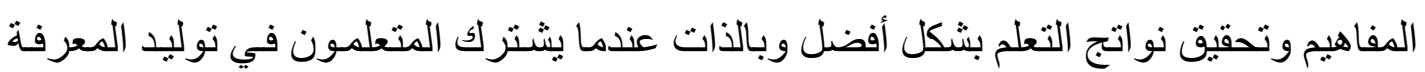
وتحمل مسؤوليات موجهة ومحددة ومحبية أثناء عمليات التعلم أكثر من استقبالها استقبالا جزئيا

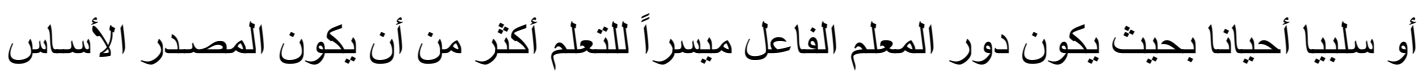

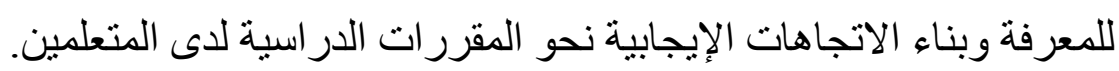

\section{بحوث مقترحة:}

في ضوء النتائج السابقة يقتر ح الباحث عدداً من الدر اسات، امتدادا لهذه الدراسة ومنها:

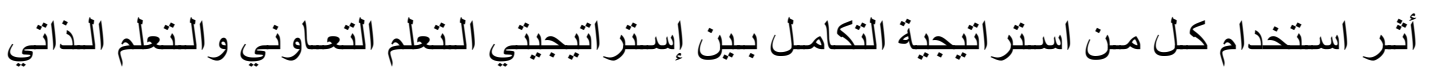

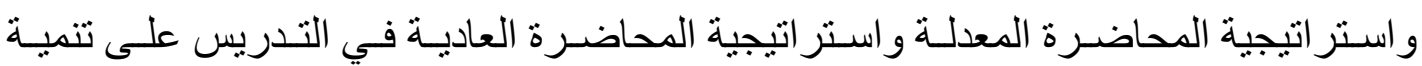
التحصيل في بعض المقرر ات الدر اسية في التعليم الجامعي.

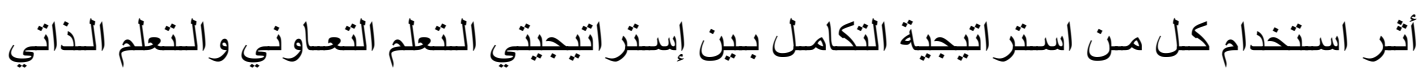

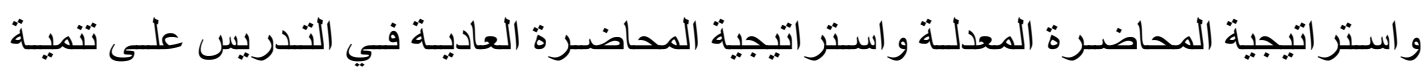
التحصيل في بعض المقرر ات الدراسية في التعليم العام.

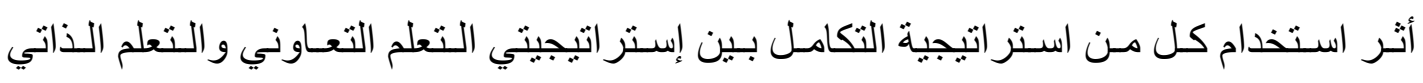

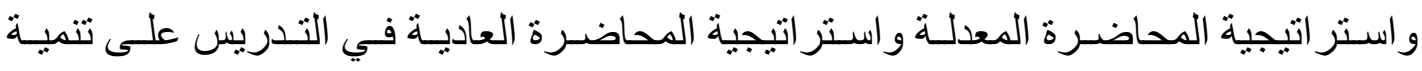


مستويات المجال النفس حركي (كمهار ات التفكير العليا ومهار ات التفكير العلمي ومهارات التفكير الناقد ومهار ات الأداء التدريسي و. ...) في بعض المقررات الدر اسية المناسبة.

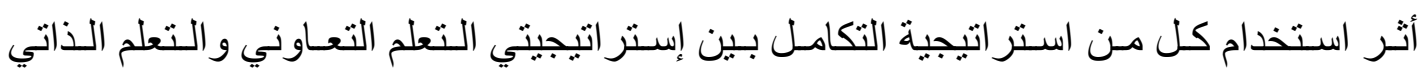

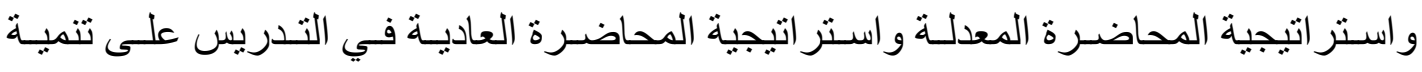

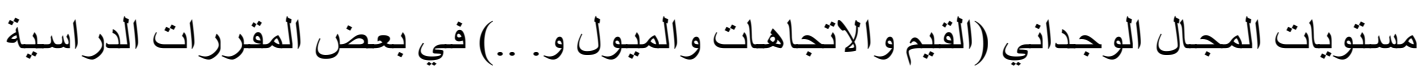
المناسبة.

$$
\text { المراجع }
$$

- إبر اهيم، مجدي عزيز (ع + . r م). استر اتيجيات التعليم و أسـاليب التعلم. القاهرة: مكتبة الانجلو المصرية.

ـ البكر ، رشيد. المهوس، وليد (19 ( الهـ). المنهج أسسه ومكوناته، الرياض، مكتبة الرشد.

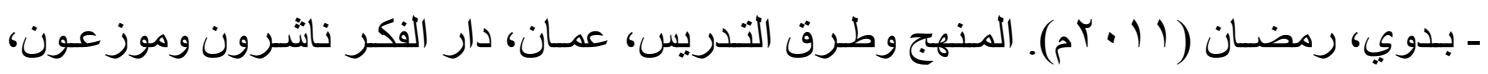

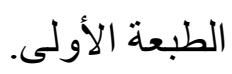
ـ الجهيمي، أحمد عبد الرحمن ( • ( • rم). فعالية استخدام استر اتيجية العصف الذهني في تحصيل

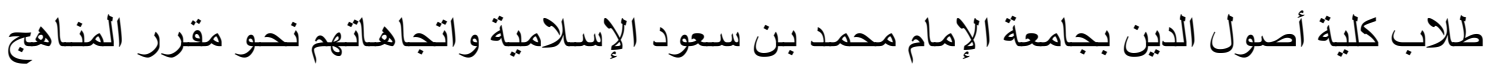
وطرق التدريس (ترب (ب0)). بحث منشور . الجمعية السعودية للعلوم التربويـة والنفسية (جستن) كلية التربية، جامعة الملك سعود. الرياض.

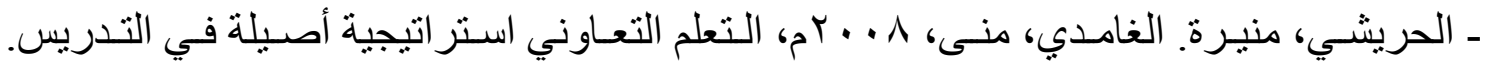

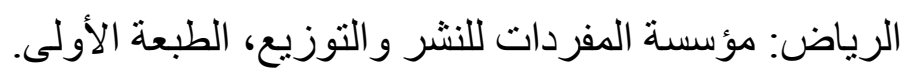

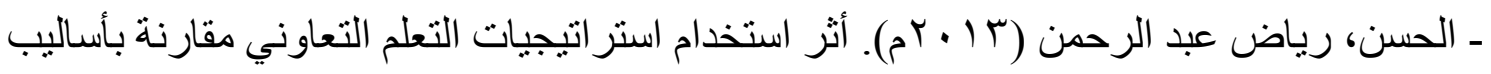

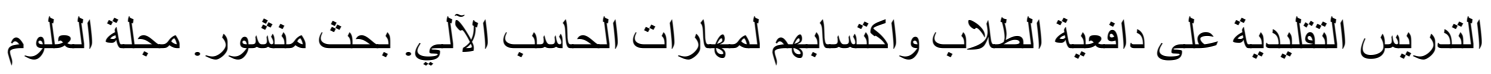

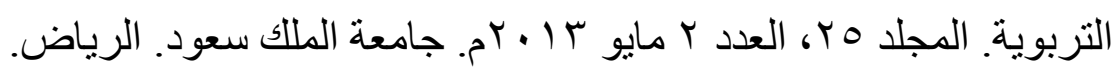

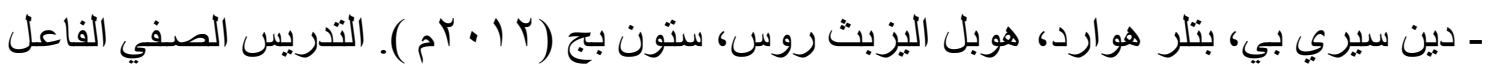

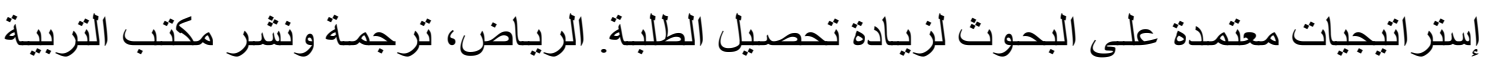

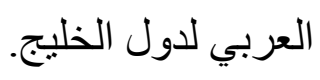




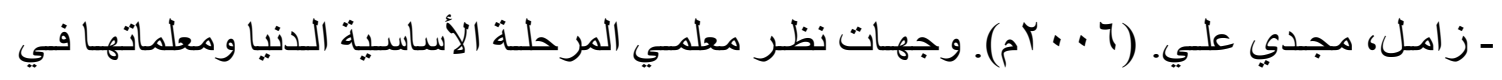

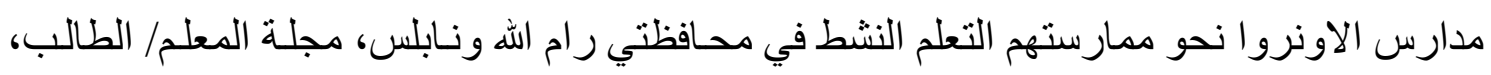

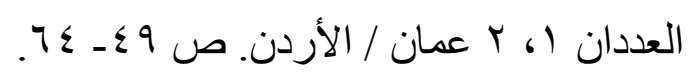

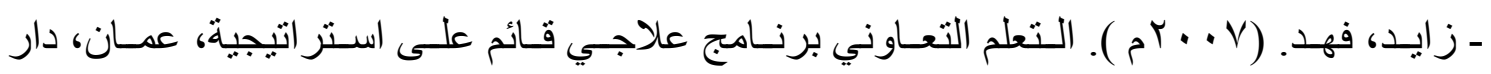
اليازوري العلمية للنشر و التوزيع. (زابع.

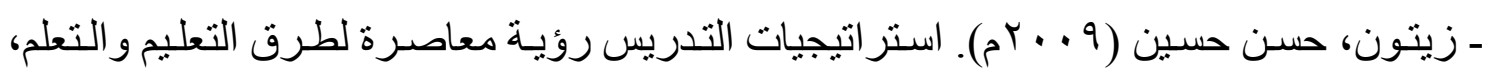
القاهرة، عالم الكتب، الطبعة الثانية.

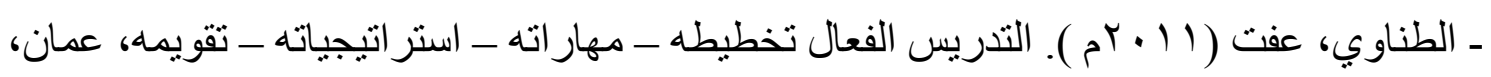
دار المسيرة، الطبعة الثانية. ـ الفتلاوي، سهيلة (· ( • r م ). المدخل إلى لتدريس، عمان، دار الثروق للنشر و التوزيع، الطبعة الأولى.

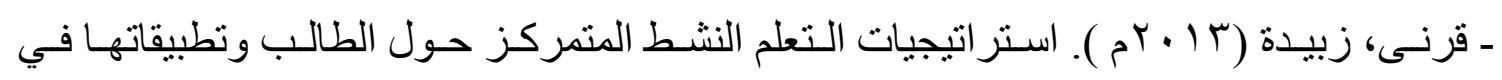

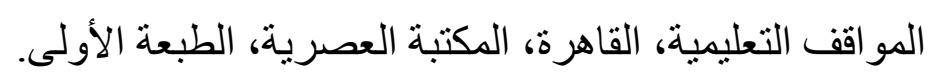

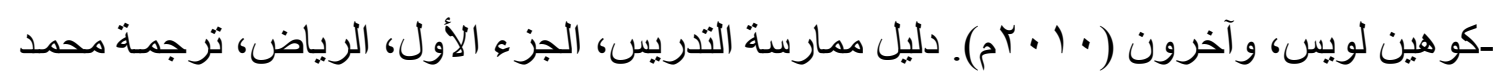
أحمد سالم، جامعة الملك سعود. -كيت إكسلي، دينيك ريج (r ( + rم). إلقاء المحاضرة من التقديم إلى التدريس،، الرياض، ترجمة هند بنت مطلق العتيبي، جامعة الملك سعود.

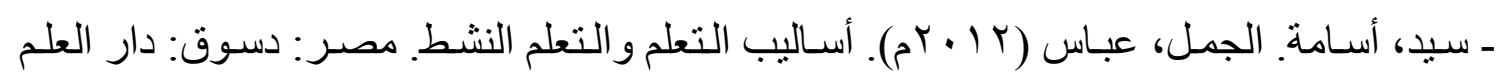
الإيمان.

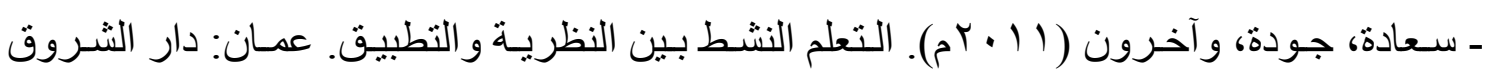
للنشر و التوزيع.

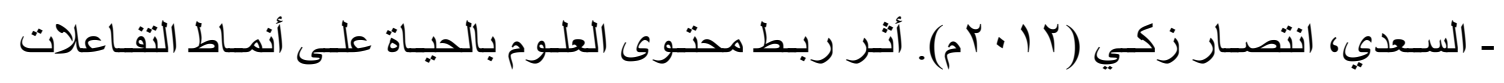

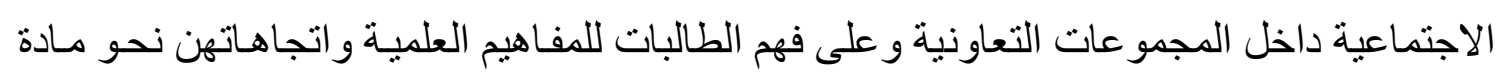

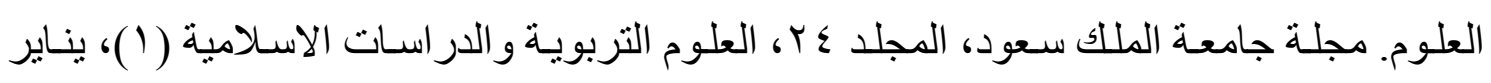
$\left(r^{2} \cdot 1 r\right)$ 


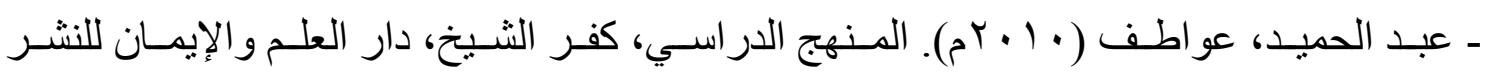

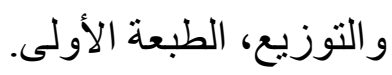
ـ عبيدات، ذوقان، عبد الحق، كايد، عدس، عبد الرحمن (ع ا ـrم ). البحث العلمي مفهومه و أدواته وأساليبه. ط7 1 ن عمان، دار الفكر.

ـ العساف، صالح (r ( • بم ). الدذخل إلى البحث في العلوم السلوكية، الرياض، مكتبة العبيكان

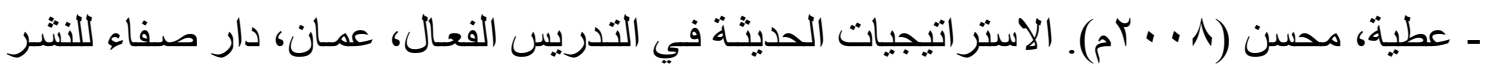
و التوزيع. ـ العنزي، سالم بن مزلوه (r ( r م). "درجة استخدام أعضـاء هيئة التدريس في التعليم الموازي

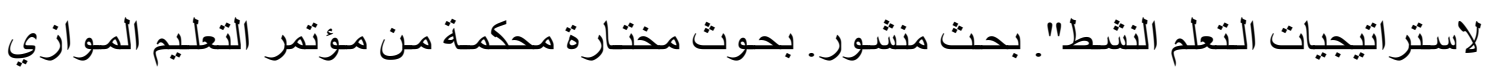

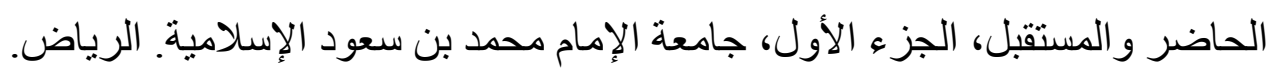

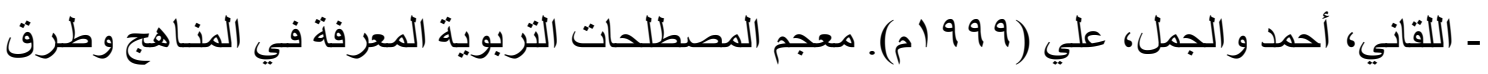
التدريس. القاهرة: دار عالم الكتب. ـ لويد، جوي مالك، وآخرون (· ( • r م). العناصر الأساسية في إدارة الفصل المدرسي إدارة الوقت

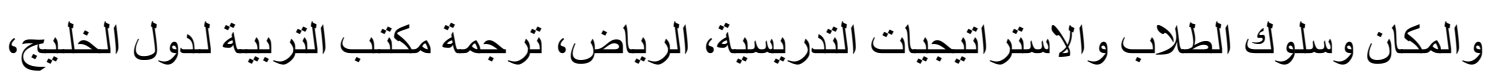
مكتب التربية لدول الخليج.

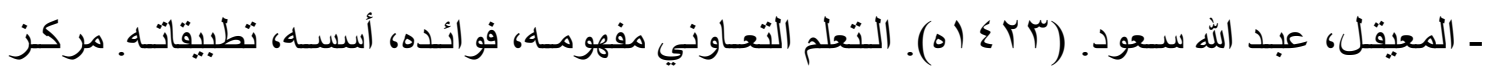
البحوث التربوية، كلية التربية، جامعة الملك سعود. ـ اليتيم، شريف سـالم (9 ـ . بـم). أثر التكامل بين إستر اتيجيتي التدريس البنائيتين: دورة التعلم، والخارطة المفاهيميـة في إدر اكات الطلبـة للبيئة التعلمية الصفية. بحث منشور. مجلة جامعة الملك سعود، العلوم التربويـة والدر اسـات الإسلامية. الرياض.

ـ النجيدي، يوسف سليمان.( آ ع ( (هـ). الكفايات التدريسية لمعلمي الرياضيات خريجي كليات

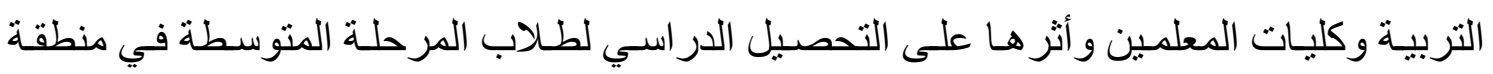
القصيم. رسالة ماجستير.كلية التربية، جامعة أم القرى.

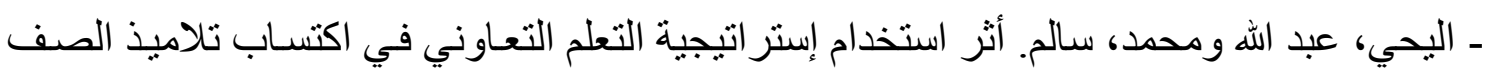

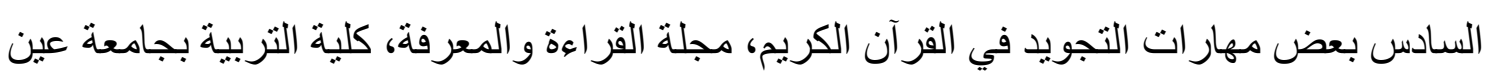

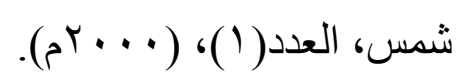


- Christianson ‘R., \& Fisher ‘Y. (1999) " Comparison of Student Learning about diffusion and osmosis in Constructivist and traditional classrooms " ‘International Journal of science Education ‘Vol.1 ‘No. 6 ، pp. $687-698$.

- Hall ‘R.E.\& Lieberman, M( 2004) Active learning guide for Lieberman 's microeconomics: Principles and applications. South Western College Publications.

- Jennifer ‘W. (2005). Active learning in transportation engineering education ‘a Ph D dissertat ،Worcester Polytechnic Institute. 